\title{
DE EUROPEËRS IN DEN MALEISCHEN ARCHIPEL
}

\author{
DOOR
}

P. A. T I E L E.

NEGENDE GEDEELTE.

1618-1623.

\section{EERSTE HOOFDSTUK.}

Tooht van Laurens Reael naar de Banda-eilanden (1618). Mislukte aanslag op Lontor door J. Dz. Lam. Steven van den Haghen gouverneur van Ambon (1617-18). De vicegouverneur Herman van Speult verovert Hutumuri, onderwerpt Boano. Voorvallen te Bantam en Djakatra in 1618. Aanslag van Pangeran Gabang op 't Hollandsche fort te Djakatra. Vijandelijkheden tusschen Engelschen en Hollanders. Coen neemt de wijk naar Ambon.

In 't begin van 1618 kwam de Gouverneur-Generaal Laurens Reael na eene afwezigheid van vier of vijf maanden 1 in de Molukken terug. Bij gebrek aan bescheiden weten wij zeer weinig van 't geen daar na zijn vertrek en in de eerste maanden na zijn terugkomst voorviel. Omtrent een aanslag dien de Ternatanen op het fort te Malajoe zouden hebben voorgehad, den 20 October 1617, is een rapport aan Reael bewaard gebleven dat weinig licht geeft; althans van den aanslag zelven vernemen wij geen bizonderheden. De reden schijnt geweest te zijn dat wel honderd hunner vrouwen en slavinnen christenen waren geworden, tegen het gemaakte contract ${ }^{2}$, wat natuurlijk de verbolgenheid van de geestelijken en zelfs van Kaitsjil Ali had opgewekt. De beslissing van het geschil werd aan Reael voorbehouden, die toen afwezig was. Coen, die de Ternatanen anders

1 Zie Achtste Gedeelte, blz. 336, 346.

2 "Waren naar Gamme Lamme gelopen en naerdatse aldaer Christenen geworden waren keerden terstont weer herwerts. Soude op 't laetste daartoe comen datter niemant en soude bij haer blijven. Waer over sy alle wilden sterven liever dan alsoo in haer wetten... geusurpeert werden." (Rapport, ongeteekend).

be Volgr. II. 
nooit verontschuldigt, vermoedde dat de Tidoreezen, die met hen over den vrede onderhandelden, hen hadden opgestookt 1.

De eerste tijding die wij weder van Reael ontvangen is uit Banda. Hij had in Juni 1617 die eilanden moeten verlaten zonder de Engelschen van Pulu Run te kunnen verdrijven ${ }^{2}$. Nathaniel Courthope was, hoewel hij met de zijnen gebrek leed, want de Engelschen te Makassar hadden geen geld om provisie voor hen te koopen ${ }^{3}$, op zijn post gebleven. Eindelijk werden in Januari 1618 drie schepen van Bantam uitgezonden om hen te voorzien en zoo noodig bescherming te verleenen, want de Engelschen begrepen wel dat men het niet bij een eerste poging om hen te verjagen zou laten Maar door slecht weder moesten zij een tijd lang te Makassar vertoeven, zoodat de Hollanders hen voor waren. Den 26 Maart kwam Reael met twee schepen voor Nera. Van der Haghen en Lam vergezelden hem. Zij vonden hier nog drie schepen en twee jachten en besloten aanstonds boven Run op de Engelschen die verwacht werden te kruisen. Den 4t April kwamen twee Engelsche schepen in 't zicht 4 en werden dadelijk door de Hollanders aangetast. Gebrek aan kruid noodzaakte hen zich na een kort gevecht over te geven, maar een twintigtal Bandaneezen, die van Bantam terugkwamen, weigerden dit en vochten zoo verwoed dat de Engelschen, uit vrees dat zij den brand in 't kruid zouden steken, de Hollanders hielpen hen af te maken. De schepen werden naar Nera opgebracht en de bemanning gevangen gezet.

Courthope was verontwaardigd dat zijne landgenooten zoo spoedig de vlag hadden gestreken. Hoewel hij slechts 38 man bij zich had, die van rijst en water moesten leven, was hij besloten zich tot het uiterste te verdedigen, "De Hollanders zijn van plan, , schreef hij aan den president Ball te Bantam, "met hun geheele macht op ons af te komen, maar als zij overwinnen zullen zij hun zegepraal duur betalen" 5 .

Dit begrepen ook zijne tegenstanders. "Pulu Run ", schreef Van der Haghen, "is een cleyn iseren lantgen; leit gelick een stadt in zee ", namelijk aan de landingsplaatsen versterkt. Bovendien hadden de Hollanders gebrek aan goede soldaten. Op Nera had een epidemie geheerscht 6 en bij de honderd man ten grave gesleept. In 't laatst

1 Coen aan Bewindh., 26 Juli 1618.

2 Achtste gedeelte, blz. 335, 336.

3 Calendar of State papers, East-Indies, II, No. 128, 332.

4 Het derde was in Straat Saleier van de anderen' afgedwaald.

${ }^{5}$ Brief van 24 April in Calendar II. No. 332. Vgl. de Preface, p. XLI-XIIII.

- Reael noemt de ziekte "pestilentiale koortse." 
van April kwamen 70-80 soldaten uit de Molukken ter versterking en werd het volk voor een landing op Run gemonsterd, maar juist begon toen de moesson door te waaien en maakte die landing zoo goed als onmogelijk.

Men beraadslaagde nu over een aanslag op Lontor. De Lontoreezen namelijk, bewoners van het westelijk gedeelte van Groot Banda, hadden weder met de Hollanders gebroken. In 1617 was de gouverneur Van de Sande gestorven en door Hendrik Waterfort opgevolgd. Deze begon aan de Bandaneezen op last van Coen weder hooger eischen te doen: zij moesten de noten gezuiverd afleveren, en toen zij dit weigerden, nam hij hun eenige prauwen af. Dit lieten zij niet ongewroken. Toen Waterfort op zekeren dag naar Groot-Banda overstak, namen zij hem gevangen en kristen den onderkoopman die zich te weer stelde. Eerst toen zij alle gevangene Bandaneezen en aangehaalde prauwen terug ontvingen, leverden zij den gouverneur weder uit. Courthope steunde hen natuurlijk in hun verzet en beloofde hun nog een jaar op versterking te zullen wachten als zij met de Hollanders geen handel dreven. Eene tuchtiging dier wederspanuigen achtten de laatsten dus noodig. Maar ook dit had groote bezwaren. "Wij weten", schreef van der Haghen, "geen rechte passage om bij hen boven te komen, want de paden zijn ongeloofelijk steil en nauw, en gemakkelijk te verdedigen. De Orangkajas te Lontor hebben al hun huizen met steenen muren rondom bewald, zoodat elk huis een fortje is " 1. Dit schrikte echter Lam, den veroveraar van Pulu Ai, niet af. Met 600 man landde hij bij Lontor en beklom de hoogte waar de voornaamste sterkte lag, maar de warme ontvangst die hem daar te beurt viel, gebrek aan water en voldoend oorlogsmateriaal noodzaakten hem weder af te trekken.

Er werd nu met die van Selama en de plaatsen die met hen verbonden waren, als Wajer en Rosengein, weder een contract gesloten om de noten te Nera te brengen, maar de Lontoreezen bleven hardnekkig. Hun eisch was dat men op Groot-Banda weder een huis betrok, hun dus een bewijs van vertrouwen gaf; dan zouden zij de geroofde goederen teruggeven. Maar die eisch werd afgeslagen. Doortastender maatregelen moesten de Hollanders echter uitstellen tot zij beter waren toegerust. Den 11 Juli 1618 keerde Reael met Van der Haghen over Ambon naar de Molukken terug 2.

1 Van der Haghen aan Bewindh., 10 Juni 1618.

${ }^{2}$ Zie over 't voorgaande: Nath. Courthope's journaal bij Purchas, I b, p. 666-671; Calendar etc. II, No. 332, 373, 408, 623; Brieven van Van der Haghen, Reael 
Het lijdt geen twijfel of noch Reael noch Van der Haghen waren voor viterste maatregelen tegen de Bandaneezen gestemd. Zij oordeelden te recht dat de schuld voor een groot deel aan de Hollanders lag. Deze eischten veel en gaven weinig of niets. Door den oorlog verarmd en uitgeput, wenschten de Bandaneezen den vrede en zouden dien gaarne gehandhaafd hebben, maar zij leden honger. Voor geregelden aanvoer van levensmiddelen werd door de Hollanders niet gezorgd, terwijl zij dit aan anderen beletten uit vrees dat deze specerijen zouden koopen, en de kleedjes die zij hun brachten waren niet de gewilde 2, En dat weren van vreemde jonken batte toch weinig of niets, want, schreef Reael, "nu zijn er honderd plaatsen op Ceram waar wij hen niet kunnen fweren en van waar zij de Bandanezen voorzien." Het diende dus slechts om ons gehaat te maken; een doel bereikte men er niet mede 3. Maar welke verzoenende maatregelen Reael en de zijnen voorstelden, Coen was daar om ze te ontraden. "De admiraal Verhaghen ", schreef hij aan Bewindhebbers 4 "wil het nog al met goed doen hebben, zeggende dat men de noten behoorde te ontvangen zoo als God die aan de Bandanezen verleent, en de Generaal Reael dat men den prijs van de noten behoorde te verhoogen en die van de foelie te verlagen, maar IK zeg $\mathrm{u} 5$ dat het een even schadelijk als 't ander wezen zal en dat men ten uiterste tegen de Bandaneezen voort moet varen." Al verlieten zij allen hun land, dat zou niet schaden; "dan kan er van andere kwartieren volk gebracht worden." Men gevoelt reeds waarop dit moest uitloopen.

Van der Haghen, door Reael tot gouverneur van Ambon benoemd omdat hij hier "zeer wel gezien en bemind was $\nu$ 6, had op 't eind van Juli 1617 het bewind van Blocq overgenomen. Ook hier dezelfde klacht: "de Hollanders willen alles hebben en geven niets. Hebben wij lang te vergeefs naar provisie uitgezien, dan komt er

en Lam aan Bewindh., van Mei-Juli 1618; Resol. GG. en R. 10 Juni-11 Juli; Contract met Selama in d. 25 Juni (Contractenboek).

${ }^{2}$ D. Pz. van de Sande aan Bewindh., 31 Aug. 1617. In denzelfden brief klaagt hij dat hij geen medicamenten ontvangt "hoewel hier alle jaren zware ziekten onder ons volk heerschen."

s Reael aan Bewindh., Nera 7 Mei 1618.

4 Den 26 Juli 1618.

"In margine staat met een oude hand: "Coens opinie die seer notabel is."

- Reael aan Bewindh., 10 Mei 1617; H. van Speult aan Bewindh. 19 Aug. 1617: novermits seer bemint van de inwoners is.." 
eindelijk wat bedorven rijst, die wij niet kunnen eten. En voor het weinige dat zij ons brengen vragen zij veel meer in ruil dan de Javanen en Makassaren, die zij beletten met ons te handelen." Was het dan wonder dat zij verlangend naar de komst der Engelschen uitzagen? Van der Haghen werd niet moede die klachten aan Bewindhebbers over te brengen en hun te betoogen hoe weinig voordeel die dwangmaatregelen gaven, een motief, meende hij, dat bij hen wel het zwaarste zou wegen.

Van der Haghen behoorde tot de weinige verlichte mannen, (die door den invloed van Coen hoe langer hoe schaarscher werden), die den inlander niet voor een schurk hielden omdat hij Mohammedaan was. Hij geloofde bij voorbeeld dat "Kapitein Hitu " het eerlijk met de Hollanders meende. 't Is waar, schreef hij ${ }^{\mathbf{1}}$, dat hij een "groot Mahometist " is, maar 't ware te wenschen dat onze predikanten en ziekentroosters evenveel ijver toonden om hun geloof te verkondigen als hij; dan zouden zooveel Christenen het "Moorsche geloof" niet aangenomen hebben. Zijne vriendschap voor den Hituees belette echter niet dat hij het proselytisme voor den Islam tegenging waar hij zag dat het slechts een dekmantel was om de Hollanders tegen te werken en dat hij eenige dorpen aan de westkust van Hitu 2 weder aan 't rechtsgebied van den Kapitein onttrok, omdat zij reeds in den tijd der Portugeezen onder 't Kasteel gestaan hadden.

Met Luhu, Kambelo en de andere nagelplaatsen op Klein Ceram bleef de verhouding gespannen, en hoe kon dit anders daar de Hollanders de jonken bleven aanhalen die hun het noodige brachten. "En 't is ook waar", schreef van der Haghen 8, "dat zij met ons veel erger conditien hebben als met de Portugeezen, want in hun tijd floreerden ze. Toen lag het overal vol jonken die hun alles brachten wat zij van doen hadden, handel dreven, tollen en ankergeld betaalden. Nu zeggen ze dat ze van ons niets genieten en geen voordeel hebben maar schade." Te vergeefs zagen de Cerammers naar hulp uit bij den Sultan van Ternate om hen tegen dien dwang te beschermen, maar het baatte weinig of hij hun al verzekerde dat de Hollanders volgens de contracten geen recht hadden om de "kooplieden Islam" overlast aan te doen. Zij dachten er dus over den Ternataanschen stadhouder te verdrijven en de Tidoreezen te hulp te

1 Bouwstoffen, door mij uitgeg., blz. 233.

2 Larike en Wakasihoe,

3 Bouwstoffen door mij uitgeg., bl. 226. 
roepen, en als Juan de Silva met zijn armada gelukkiger was geweest, twijfelde Van der Haghen geen oogenblik of wij zouden dat land geheel verloren hebben.

Toen in 1618 Van der Haghen als raad van Indië den GouverneurGeneraal naar Banda en de Molukken vergezelde, werd het bestuur op Ambon waargenomen door den luitenant-gouverneur Herman van Speult. Hij had op voorname punten hetzelfde inzicht als zijn voorganger. Het gedwongen werken der inlanders aan de vesting keurde hij af; evenzeer het weren der Javaansche en andere jonken 1. Toch wist hij met vaste hand den teugel te voeren. De bewoners van Hutumuri, een viertal kampongs aan de oostzijde van Leitimor hadden in den tijd van Houtman (1611), tot straf voor het afloopen van de kampong Ruton en andere rooverijen, hunne oude woonplaatsen moeten verlaten, zich bij 't kasteel moeten vestigen en manschappen leveren om daar te werken. Na Houtman's vertrek waren zij langzamerhand weer naar hun oude woonplaatsen in 't gebergte teruggekeerd, weigerden voortaan aan ' $t$ kasteel te komen, gaven voor dat zij Mohammedanen wilden worden, en kwamen zelfs koppen snellen bij onderdanen van de Hollanders. Vermoedelijk was dit laatste slechts weerwraak, want Van Speult had de bewoners der overige bergdorpen last gegeven hetzelfde te doen en zelfs getracht, op het voorbeeld van Blocq, Alfoeren van Ceram te laten komen om hen op die wijze tot gehoorzaamheid te dwingen ${ }^{2}$. Hij zag nu dat dit middel geen doel trof en besloot andere maatregelen te nemen. Toen het weder het toeliet, in 't laatst van September 1618, begaf hij zich met 70 soldateu en 1000 Ambonners naar de pas van Baguala, van waar zij den volgenden morgen naar het strand bij Hutumuri voeren. De Ambonsche hoofden deden hun best de opstandelingen tot onderwerping te bewegen, maar vertrouwende op de ongenaakbaarheid hunner rotssterkten weigerden zij af te komen en beriepen zich op kapitein Hitu, die den vrede wel zou herstellen 3. Van Speult begreep echter dat hij moest doortasten. Een troepje soldaten, naar boven gezonden op verkenning, bracht er den schrik in, zoodat zij een versterkt punt, dat zij gemakkelijk

1 Van Speult aan Bewindh., 19 Aug. 1617; 4 Juni 1618.

2 Van Speult aan Bewindh., 8 Aug. 1618; Resol. Ambon 30 Juli 1618.

3 Eerst hadden zij het hoofd geëischt van zekeren Don Pedro, "dat haer rechte hooft was", schrijft Van Speult, "die sy over eenigen tijt verworpen hadden" en dien zij de oorzaak van het geschil met de Hollanders noemden. Van Speult schijnt dit als een voorwendsel beschouwd te hebben. 
tegen de overmacht hadden kunnen verdedigen, in allerijl verlieten. $\mathrm{Nu}$ was het volk, soldaten zoowel als inlanders, vol vuur om eene tweede sterkte, niet ver van daar gelegen, aan te tasten. Van Speult stond dit slechts schoorvoetend toe omdat het meerendeel der hulptroepen en het stormgereedschap aan 't strand was achtergebleven. De uitkomst was zoo als hij verwacht had: de aanval werd afgeslagen, en nu moest Van Speult tot bedreigingen overgaan om de inlanders te bewegen dien met alle macht te hervatten. De tweede aanval had beter gevolg. Na geringen wederstand verlieten de weerspannigen ook deze sterkte. Vol moed werd nu ook een derde fort van twee kanten aangetast, en door de Hutumureezen verlaten, die zich thans in hun kampong Maut, met een steenen muur omringd, op een goed verdedigbare hoogte gelegen, terugtrokken. Belust op buit, wilden de Ambonners die onmiddellijk bestormen, maar werden teruggedreven. Van Speult begreep dat, als hij haar met storm veroverde, de meeste mannen de vlucht zouden nemen en de Ambonners hun wraak zouden koelen aan de vrouwen en kinderen; hij liet dus aan de belegerden lijfsgenade aanbieden als zij zich overgaven. Dit aanbod werd met graagte aangenomen en den volgenden dag trok Van Speult de kampong binnen. Zij werd in brand gestoken en de muren geslecht; de inwoners met vrouwen en kinderen, te zamen 350 personen, moesten hem naar 't kasteel volgen, waar zij onder de bondgenooten verdeeld werden. Ook de vluchtelingen werden in de naburige Hitueesche dorpen opgeëischt, en de schrik was er zoo ingebracht dat zij ze allen uitleverden en zich veel volgzamer betoonden dan voorheen 1.

$\mathrm{Na}$ dezen welgelukten tocht besloot Van Speult een ander plan ten uitvoer te brengen. De bewoners van eenige kampongs aan den noordwesthoek van Ceram 2 en van de naburige eilanden Boano, Kelang en Manipa hadden zich sinds menschen-geheugenis toegelegd op zeeroof en in de laatste jaren wel 200 man uit omgelegen plaatsen, die onder de bescherming van 't Kasteel stonden, opgelicht en als slaven verkocht. Dit mocht niet langer geduld worden. Gesteund door kapitein Hitu, die in persoon aan den tocht wilde deelnemen, bracht Van Speult 35 korakora's met'3500 inlanders bijeen, sloot zich met 60 soldaten daarbij aan en stak den 4 November 3618 met de vloot in zee. De hoofdmacht te Hitu achterlatende, bracht hij

1 Van Speult in Bouwstoffen, bl. 235-242; Resol. Ambon 14 Sept., 5 Oct. 1618.

2 Genoemd worden Assahudi (op Klein Ceram), Lisabata (aan de noordkust) en "Hateboute". Dit is waarschijnlijk Hataputeh op Kelang. 
eerst een bezoek aan Kimelaha Sabadin, den Ternataanschen stadhouder op Luhu en onderhield hem over den geringen steun dien hij de Hollanders verleende tegen de kwaadwillige hoofden in de nagelplaatsen en de onverschilligheid waarmede hij den zeeroof aanzag, door onderdanen van Ternate gepleegd. Sabadin betoogde dat hij niet bij machte was dien te beletten en waarschuwde Van Speult voor de inwoners van Boano, "een vermaard en kloek volk" dat de Portugeezen te vergeefs getracht hadden te onderwerpen. De gouverneur liet zich hierdoor niet afschrikken, maar voer met de vloot van Hitu rechtstreeks naar Boano, waar hij den 14 November aankwam en den Sengadji, die daar namens Ternate heette bevel te voeren, ter verantwoording riep over de gepleegde rooverijen. De Sengadji gaf eerst een uitdagend bescheid, maar ziende dat de Hollanders aanstalten maakten voor eene landing, en waarschijnlijk door kapitein Hitu op de hoogte gebracht van Van Speult's vastberadenheid, onderwierp hij zich een paar dagen later, beloofde de geroofden die nog in leven waren terug te geven, voor de anderen een schadevergoeding te betalen en te zorgen dat voortaan geen zeeroof meer gepleegd werd. Op deze voorwaarden werd een verbond met hem gesloten. $\mathrm{Nu}$ voer Van Speult met de hongi naar Assahudi op Klein Ceram, waar hij de inwoners op dezelfde voorwaarde in genade aannam. Een tocht naar Lisabata moest tot later worden uitgesteld, maar te Kambelo, waar hij levensmiddelen innam, werden de hoofden van Kelang en Manipa ontboden, die eveneens restitutie en schadevergoeding beloofden $\mathbf{1}$.

Dat de indruk, door Van Speult gemaakt, niet voorbijgaand was blijkt wel hieruit dat Lisabata uit eigen beweging een aantal geroofden aan Speult nitleverde 2.

De wakkere bewindvoerder zag zeer goed in dat hij om zijn gezag te handhaven de kustplaatsen en eilanden die dat gezag erkend hadden, ook moest bezoeken en beschermen. Op de Uliasers en aan de zuidkust van Ceram nam de propaganda voor den Islam, vooral van Banda uit, zeer toe ${ }^{3}$, en 't was maar al te waar dat dit niet zelden met tegenstand tegen 't Hollandsche bewind en vijandelijkheden tegen zijne voorstanders gepaard ging. Een jaarlijksche ronde

1 Van Speult aan Bewindh. in Bouwstoffen, enz. blz. 242-45; Resol. Ambon 21 Nov. 1618; Contract met Boano bij Valentijn, II 2, p. 41.

2 Bouwstoffen enz. bl. 254.

s Welk een invloed de Mohammedaansche godsdienstleeraars hadden blijkt wel uit hetgeen van Speult verhaalt (Bouwstoffen, bl. 247) dat 150 lieden van Nusalaut 
zou veel toebrengen om "de Mooren binnen hunne limiten te houden" betoogde Van Speult aan Bewindhebbers, en deze antwoordden hem dat zij dit "oorbaar" vonden, maar daartoe had hij versterking van 't garnizoen noodig 1.

Die versterking werd hem in 't laatst van 1618 gezonden, maar met een ander doel. De Engelschen te Bantam, die eene aanzienlijke versterking hunner scheepsmacht verwachtten, schenen voornemens te zijn met alle macht naar de Specerij-eilanden te varen. Coen zond hierop ijlings den commandeur Arent Maertsen met een goed bemand schip naar Ambon, met last om alle specerijen op te koopen vóór de komst der Engelschen 2. Van Speult moest nu tegen de hoofden een anderen toon aanslaan, en zij zullen wel verwonderd hebben opgezien op eens allen een vereering te ontvangen en de verzekering dat men de Javaansche, Maleische en Makassaarsche jonken geen overlast zou aandoen. Van Speult nam echter tevens de voorzorg het fort Luhu met honderd man te bezetten 3 .

Maar in plaats van een Engelsche vloot verscheen den 4 Februari 1619 een Hollandsche met den Gouverneur-Generaal zelven aan boord in de Ambonsche wateren. Wat hiervan de aanleiding was hebben wij thans te verhalen.

In de tweede helft van 't jaar 1618 en 't begin van 't volgende werd door Europeërs en Javanen te Bantam en te Djakatra een drama gespeeld, waarvan wij ons een duidelijker voorstelling zouden kunnen maken, indien wij niet slechts van ééne zijde waren ingelicht. Javaansche documenten ontbreken bijna geheel en de Engelsche laten in volledigheid veel te wenschen over. Coen, het is waar, heeft aan Bewindhebbers van al het gebeurde volledig verslag gegeven, maar Coen's gezichtspunt was uiterst eenzijdig. Dat de Engelschen hem haatten begreep hij even goed als dat de Javanen hem trachtten te misleiden, maar dat hij door zijn macht te misbruiken zelf oorzaak was van hun wantrouwen en tegenwerking, dat hij geen recht had iets anders te verwachten, zag hij niet. Wij zouden, alleen op zijn berichten afgaande, gaan gelooven dat de Hollanders de oprecht-

met veel geschenken aan 't Kasteel kwamen en daar zes weken arbeid verrichtten, alleen om een "Bandaneeschen paap" los te krijgen, dien Van Speult had gevangen gezet.

1 Bouwstoffen, bl. 246; 247 ; Bewindh. aan Speult 22 Dec. 1620.

2 De Jonge, IV bl. 115; Resol. Ambon 28 Dec. 1618.

3 Resol. Ambon 28 December 1618; 16, 18, 20 Januari 1619. 
heid en onschuld zelve en alle anderen schavuiten en samenzweerders waren $\mathbf{1}$.

De Engelsche Compagnie miste den steun van hare Regeering. Jacobus I wilde niet dat zij tegen Spanje vijandelijk optrad, en het Spaansche goud deed veel af om die gezindheid ook bij zijne raadslieden levendig te houden 2. Dit was dan ook het voorname bezwaar waarop de pogingen, in Europa aangewend om aan de handelsgeschillen tusschen Engeland en Nederland in Indië door de vereeniging hunner compagniën een einde te maken, waren afgestuit 3. De Hollanders waren eenmaal begonnen aan de Spanjaarden en Portugeezen in Indië met de wapenen het monopolie te betwisten, en niet gezind aan anderen, die niet aan de oorlogskosten bijdroegen, de voordeelen daarvan te laten genieten. Dit gold hoofdzakelijk de Specerij-eilanden, waar zij meesters waren, en er is geen twijfel aan of de Engelschen hadden dit in hun plaats evenmin toegestaan. Maar eenmaal in den Archipel gevestigd, konden ook dezen den handel op de Molukken niet opgeven zonder van de grootste voordeelen die de vaart naar Indië opleverde afstand te doen. En zij hadden genoeg gezien om overtuigd te zijn dat de inlanders hen met open armen zouden ontvangen om van den dwang der Hollanders verlost te worden. De Engelsche Compagnie besloot dus haar recht om aan de vaart op de Molukken deel te nemen te handhaven. Eene nieuwe inschrijving had haar kapitaal aanzienlijk vermeerderd 4 en stelde haar in staat eene grootere scheepsmacht naar Indië te zenden. In den loop van 1618 verzamelde zich die te Bantam. In 't laatst van Juni kwam daar een eskader onder Thomas Pring en in 't begin van December een tweede onder Sir Thomas Dale, aan wien John Jourdain, de oude tegenstander der Hollanders 5 als hoofd van den handel was toegevoegd. Op 't eind van dat jaar hadden dus

1 De heer J. A. van der Chijs in zijne uitmuntende monographie "De Nederlanders te Jacatra, uit de bronnen bewerkt" (Amst. 1860) spaart de Hollanders niet. V. d. C. heeft van het verhaal van Camphuis (bij Valentijn, dl. IV), de Resolutien van GG. en Raden, enz. een oordeelkundig gebruik gemaakt; de brieven van Coen en andere stukken, die later openbaar zijn gemaakt, maken een herziene uitgaaf van dit werkje wenschelijk.

2 Zie o. a. S. R. Gardiner, History of England, 1603-1642. London 1885. Vol. I p. 215, 354.

$\checkmark$ De Jonge IV. Inl. bl. LXXVIII.

4 David Macpherson, History of the European commerce with India, p. 98.

${ }^{5}$ Zie Achtste gedeelte, bl. 284. Hij was in December 1616 naar Engeland vertrokken. (Purchas, I b, p. 672). 
de Engelschen onder Dale's opperbevel eene vloot van 15 schepen bijeen.

Te Bantam had hun opperkoopman George Ball zich kort voor Dale's komst den rijksbestuurder Aria Manggala tot vijand gemaakt door een Chineesche jonk die op de reede lag voor schuld in beslag te nemen 1. De Javaan was zoo vertoornd dat hij Ball niet meer ontvangen wilde en de Hollanders een handelsverbond met uitsluiting van andere Europeesche natiën voorspiegelde 2. Maar toen de Engelschen hem een aanzienlijke schadevergoeding gaven kwamen zij weer in de gunst $\mathbf{3}$.

Even als de Pangeran te Bantam toonde te Djakatra de inhalige regent Widjaja Krama dan eens meer genegenheid aan de Hollanders, dan weer meer aan de Engelschen, naarmate zijn belang of vrees dit medebracht. Coen meende hem door milde geschenken voor zich gewonnen te hebben en had ook zonder verderen tegenstand de Hollandsche loge van steen opgebouwd en eenigszins ter verdediging geschikt gemakt. Maar op eens bespeurde hij dat de Regent hem met wantrouwen bejegende. De rijksbestuurder van Bantam had een broeder, Aria Upa Pati, in de wandeling Pangéran Gabang geheeten, een eerzuchtig man die gaarne zelf koningje wilde spelen en eenige jaren te voren Widjaja Krama had trachten te bewegen hem Ontong Java af te staan. Deze Gabang nam thans den schijn aan van groote genegenheid voor Coen, hoewel hij vroeger den regent van Djakatra geraden had de Hollanders om hals te brengen en zich hun goederen toe te eigenen. Terwijl zijn broeder te Bantam met Arent Maertsen beraadslagingen hield over het handelscontract, had hij zich beoosten Djakatra op de jacht begeven en op zijn verzoek had Coen hem een Hollandsch jacht tot convooi medegegeven. Terugkeerende zond hij den Gouverneur-Generaal een boodschap dat hij zich op het eilandje Putri bij Djakatra bevond en hem daar gaarne wilde spreken. Hij zou wel gaarne de Hollandsche loge te Djakatra zien maar kon dit niet doen tenzij de regent hem ontbood. Toen Coen op het eilandje aan wal stapte, gaf Gabang hem zeer verheugd te kennen dat hij te

1 Pring by Purchas, I b, p. 633. Vgl. Calendar II, No. 362.

${ }^{2}$ Coen bij De Jonge, IV, bl. 98.

s Gilles Seys, ten anker voor Djapara, aan Arent Maertsen, Commandeur voor Bantam, 15 Oct. 1618. Heeft vernomen van den vorst van Tjeribon dat de Engelschen te Bantam en te Djakatra meer gezien waren dan de Hollanders daar zij uit de geplunderde Chineesche jonken aan den Pangeran en de Panggawa's 8000 realen van achten geschonken hadden. 
Djakatra ontboden was en voer te gelijk met hem, met een gevolg van 300 man naar de stad. Het blijkt dat er verstandhouding bestond tusschen Gabang en eenige Javaansche grooten te Djakatra, die de Hollanders niet genegen waren. Dien dag, het was de 20 Augustus 1618 , bespeurde Coen veel beweging in de stad en zag hij dat een aantal vrouwen deze met hun bagage verlieten. Des avonds, terwijl men in de Hollandsche loge het avondgebed deed, kwam op eens Gabang met den broeder van den Regent en hun beider gevolg, meer dan $500 \mathrm{man}$, aan de poort toegang vragen. Coen liet onmiddellijk zijn soldaten, 40 à 50 in getal, in de wapenen komen en plaats vatten op een bovengallerij, waar men hen niet kon overvallen. Daarop werd de poort geopend en leidde Coen de Pangerans met hun gevolg in de loge rond. De Javanen hadden ons, schreef Coen, "met voeten wel dood kunnen loopen ", maar Gabang begreep zeer goed dat de soldaten niet voor niets hun lonten brandende hielden en vertrok even vriendschappelijk als hij gekomen was $\mathbf{1}$.

Den volgenden dag ontving Coen een bezoek van Widjaja Krama, die het deed voorkomen alsof hij zijne Orangkaja's met Gabang had medegezonden om Coen hulp te verleenen als de Pangeran verraad had willen plegen. Waarschijnlijk had hij niet kunnen beletten dat zijne volgelingen, die de plannen van Coen niet ten onrechte mistrouwden, zich bij Gabang ansloten. Want dat hij zelf den Bantammer, dien hij niet vertrouwde, in zijne plannen gesteund zou hebben, komt mij zeer onwaarschijnlijk voor.

Gabang was daags na den mislukten aanslag naar Bantam teruggekeerd. Coen besloot voorloopig noch daar, noch te Djakatra zijn mistrouwen te laten blijken, hoewel hij het geld en de kostbaarste goederen in de schepen liet brengen. Hij dacht er nu eerst over om op het eilandje Onrust, waar de schepen lagen en waar de zieken heengebracht werden, een reduit op te werpen, maar bij nader inzien kwam het hem voor dat de loge te Djakatra zonder groot bezwaar zoo versterkt zou kunnen worden, dat men een anval van de Javanen niet te vreezen had. De 22e October 1618 was de merkwaardige dag waarop hij in eene algemeene vergadering van alle opperkooplieden, scheepsbevelhebbers en officieren, de zaak wijd en breed voorstelde, en waarop ten slotte het besluit werd genomen,

1 Coen bij De Jonge, IV bl. 98-102; vgl. bl. 78 ond.; "Diversche Dischursen met de Sabandaer en Orangquais van Jacatra" onderteekend Hen. de Haen medicus, in d. 18 Sept. 1618. 
"met de versterking der loge voort te varen en haar tegen alle geweld in volkomen defensie te brengen " $\mathbf{1}$.

De handschoen was hiermede aan de Javanen toegeworpen, want het bouwen van een vesting hadden zij met het oog op Malaka tot nu toe altijd weten te beletten. Widjaja Krama hield zich wel alsof hij de redenen die Coen hem gaf voor het aanleggen van nieuwe versterkingen billijkte, en de Pangéran Aria Manggala veinsde wel zich niet te willen bemoeien met hetgeen de Hollanders te Djakatra uitvoerden, maar beiden verboden toch aan Javanen en Chineezen hun hulp te verleenen of of bouwmateriaal te leveren. Ook togen de Djakatranen aanstonds aan het werk om de muren hunner stad aan de zijde der loge te voltooien en te versterken en de voornaamste huizen aan dien kant van schootvrije staketsels of wallen te voorzien 2 .

Toen de goede verstandhouding met de Hollanders verminderde, had de Regent van Djakatra weder meer het oor geleend aan de voorstellen der Engelschen, en den 6 October was men het eens geworden over de som die zij jaarlijks zouden moeten betalen en hadden zij vergumning gekregen tot het bouwen eener loge 3. Daar de Regent begon in te zien dat een conflict met de Hollanders niet kon uitblijven polste hij den Engelschen koopman of zijne landgenooten geneigd zouden zijn hem in dat geval hulp te verleenen. Nicholas Ufflete verontschuldigde zich en zeide dat zij kooplieden waren en niet nitgezonden om iemands partij te kiezen, maar hij twijfelde niet of de vorst van Bantam zou hem bijstaan. "Bantam voor zich ", antwoordde hierop Widjaja Krama, "zoo ook Djakatra " 4. Hij zag waarschijnlijk zeer goed in waarop die halp van Bantam zou nitloopen.

$\mathrm{Na}$ de komst van Dale begonnen de Engelschen anders te spreken. Thomas Dale was een man van naam. De jeugdige kolonie Virginia in Amerika had hij met beleid bestuurd. Te voren had hij in Nederland de Spanjaarden helpen bevechten, maar het schijnt dat hij ontevreden hun dienst verliet 5. De toestanden in Indie waren hem vreemd, maar naast hem stond John Jourdain, de oude tegenstander

1 Coen bij De Jonge, bl. 103-109; Resol. Djakatra, 22 Oct. 1618.

1 Coen bij De Jonge, bl. 109-115.

s Calendar II. No. 420, 423, 447, 643; M. Pring bij Purchas I b, p. 634.

4 Ufflete aan Ball, 20 Nov. 1618, in Calendar II, No. 490.

5 Zie Calendar 11 , No. 288. 
van Coen, een man van ervaring en geestkracht. In Dale's instructie was hem voorgeschreven dat hij geen vijandelijkheden tegen bondgenooten zou beginnen, tenzij hij hiertoe uitgedaagd of gedwongen werd (" provoked or driven ") of zich genoodzaakt zag tot schadeverhaling wegens geleden verliezen 1. Toen hij dus, voor Bantam komende, vernam dat de Hollanders zich niet ontzien hadden voor Banda Engelsche schepen te veroveren en de bemanning gevangen te houden was de Engelsche scheepsraad ten volle gerechtvaardigd met het besluit te nemen 2 om tegen de Hollanders vijandig op te treden. Hij kon dit te veiliger doen omdat Coen door het afzenden van schepen naar verschillende handelsplaatsen ${ }^{3}$ zijne macht zeer had verzwakt.

Het geluk diende de Engelschen, dat eenige dagen later een geladen Hollandsch schip, de Zwarte Leeuw, van Patani komende, genoodzaakt was voor het eiland Pandjang niet ver van Bantam de ankers uit te werpen. Door vier Engelsche schepen omringd, begreep de bemanning dat tegenstand vruchteloos zou zijn en gaf zich over. Coen schreef aanstonds aan Dale dat hij niet begreep wat de reden was van die daad van vijandschap en verzocht het schip an hem uit te leveren. Ook eischte hij dat Nicholas Ufflete, de Engelsehe koopman te Djakatra gestraft, zou worden wegens het verraad tegen hem gesmeed 4. Te gelijker tijd deed Coen zijn beklag bij de vorsten van Bantam en Djakatra over Dale's handelwijze; maar beiden antwoordden hem dat zij zich in hun geschillen onzijdig hielden. De Pangeran te Bantam merkte te recht op dat Coen met de Fransche schepen eveneens had gehandeld.

Den 23 December 1618, den dag na het afzenden van zijn brief aan Dale, dus vór hij diens antwoord had kunnen ontvangen s trad Coen te Djakatra zelf vijandig tegen de Engelschen op. Hij

1 Rymer, Foedera. Ed. III. Tom. VII 3, fol. 40. Vgl. De Jonge, p. LXXXI en Calendar II, p. 56, 57, 103, 132.

3 "For satisfaction of their former losses." Dale aan Bewindh. der Eng. Comp. in Calendar II, No. 609.

s Vgl. hiervoor bl. 207. Terecht heeft Van der Chijs (De Nederl. te Djakatra bl. 44 vv.) dit gelaakt.

4 Brief van Coen in d. 22 Dec. in Calendar II, No. 500; Resol. Bantam 16 Dec. Vgl. Coen bij De Jonge p. 119. - Van dit verraad is in Engelsohe stukken niets te vinden. Ufflete zou een aanslag op Coen's leven hebben beraamd. Vgl. Van der Chijs, a. w. p. 23.

5 Wat Dale mondeling tot den bode gezegd zou hebben, kon natuurlijk niet als antwoord op een officieele missive gelden. Vgl. Pring in Calendar, II p. 265. 
had het verzoek van den Regent om het versterken van de loge te staken afgeslagen en nu waren de Javanen begonnen voor de Engelsche loge, die tegenover de Hollandsche lag, aan de andere zijde der rivier, een schootvrije batterij op te werpen. Aan het gevaar van zoo nabij uit Engelsch geschut beschoten te worden begreep Coen dat hij zich niet mocht blootstellen. Hij liet daarom de Engelschen waarschuwen dat hij die werken zou slechten indien men er mede voortging. Zij antwoordden hem dat niet zij die werken maakten maar de regent van Djakatra. Hierop liet Coen een uitval doen. De nieuwe batterij werd vernield, de Engelsche loge en alle huizen die rondom de Hollandsche loge lagen in brand gestoken. De Javanen hadden zich uit de voeten gemaakt zonder tegenweer te bieden. $\mathrm{Zij}$ begonnen uu echter van hunne muren de Hollanders te beschieten, 't geen dezen niet onbeantwoord lieten. Een tweede uitval om eene batterij, die de Javanen aan den mond der rivier hadden opgeworpen, te vernielen, mislukte, en de voorraad kruid, dien de Hollanders bezaten, was zoo gering dat het er hachelijk voor hen begon uit te zien, te meer daar de rivier in de macht van den vijand bleef en men vreesde dat deze haar zou verleggen om de belegerden van drinkwater te berooven. Ook had men te verwachten dat de Bantammers en Engelschen bijstand zouden komen bieden. De meerderheid van den Raad achtte het dus wenschelijk Djakatra te verlaten ${ }^{1}$. Men aarzelde echter nog hiertoe over te gaan en besloot slechts de schepen van 't eiland Onrust te ontbieden en de voornaamste goeder en daarin te bergen. Toen deze waren aangekomen, werd het plan beraamd om den volgenden dag, den 30 December, nogmaals met alle manschappen een poging te doen om het vijandelijke bolwerk aan den mond der rivier te vernielen. Maar toen men aan 't overleggen was hoe dien aanval in 't werk te stellen kwam de Engelsche vloot in 't zicht. Aanstonds werd nu het moedige besluit genomen dat Coen onmiddellijk scheep zou gaan en met zijn eskader van 7 schepen de Engelschen te gemoet zou loopen. Het bevel over de bezetting die in 't fort achterbleef, 240 weerbare mannen waarvan 160 Hollanders, ontving de opperkoopman Pieter van den Broecke, een wakker en ondernemend man, die zich naam had gemaakt door zijn gewáagden tocht met een handvol soldaten dwars door Dekhân, van de west- naar de oostkust, maar die het vertrouwen dat thans in zijn beleid gesteld werd zou beschamen 2 .

1 Resol. 26 Dec. 1618.

${ }^{2}$ Coen bij de Jonge, bl. 117-125; MS. Journaal van Pt. van den Broecke (ter Leidsche Universiteits-Bibliotheek) fol. $62 \mathrm{vv}$. 
Den 31 December kwam de Engelsche vloot, die uit 11 schepen bestond, met den zeewind op de Hollandsche af. Dale liet deze door een trompetter opeischen, maar ontving ten antwoord dat, als hij de Zwarte Leeuw niet teruggaf, de Hollanders wraak zouden nemen. Eerst den 2 Januari 1619 raakten de vlooten slaags. De Hollanders weerden zich dapper, maar het was een geluk voor hen dat slechts enkele Engelsche schepen, waarschijnlijk bij gebrek aan volk, aan 't gevecht konden deelnemen. De strijd duurde niet langer dan drie uren en werd door de Engelschen het eerst gestaakt, zoodat de Hollanders zich de overwinning toeschreven 1 . Den volgenden dag namen de laatsten in beraad of zij zich opnieuw aan een gevecht zouden wagen, maar er bestonden overwegende redenen om dat niet te doen: gebrek aan kruid, zwakheid aan volk, meer uitzicht op schade dan voordeel, daar hunne schepen rijk geladen, de Engelsche daarentegen ongeladen en bovendien beter zeilers waren. Zij besloten dus naar Djakatra terug te keeren en met de bezetting te overleggen wat verder te doen. Maar nauwelijks waren zij onder zeil of de Engelsche vloot, die nu 14 schepen sterk was, volgde hen op den voet. Er was nu geen tijd tot overleg met die van ' $t$ fort. Men moest kiezen, de Engelschen afwachten of wijken. Hoe zwaar het Coen ook viel zijne nieuwe stichting onbeschermd te verlaten, de kansen stonden te ongelijk en er was te veel aan gelegen om de vloot te behouden, want, leed zij de nederlaag, dan zouden de Engelschen voor geruimen tijd "meesters van 't veld" blijven. Het besluit was dus: de wijk nemen naar Ambon om daar alle macht te verzamelen en zoo spoedig mogelijk terug te keeren ${ }^{2}$. Een fregat werd naar straat Sunda gezonden om de schepen die uit Nederland kwamen te waarschuwen en het schip Delft moest, Straat Bali door, zich naar het vaderland spoeden om Bewindhebbers van het gebeurde kennis te geven.

Terecht verweet Coen aan Bewindhebbers dat zij er voortdurend op hadden aangedrongen in Indië een "rendez-vous" te kiezen, en nu dit geschied was en men zich versterkt had liep alles gevaar verloren te gaan bij gebrek aan soldaten en oorlogsbehoeften. Het was alsof Bewindhebbers van de toerustingen der Engelschen

1 Zie den brief van Dale, Calendar No. 609 en Inleiding p. XXI, dien van Pring, ald. No. 643, dien van John Byrd, ald. No. 979 en vgl. ook No. 643. De Engelschen hadden weinig gezond volk en zullen dit op hun beste schepen gebracht hebben. Zie verder Coen bij De Jonge, IV bl. 127, 128; Resol. scheepsraad 3 Jan. 1619.

${ }^{2}$ Coen bij De Jonge, IV, bl. 128-30; vgl. de Inleiding, bl. LXXXIX-XC. 
geen kennis hadden gedragen. $\mathrm{Z}_{i j}$ zouden er nu zelven de schade van ondervinden 1.

En zeker, indien onder de Engelschen in Indië evenveel tucht had geheerscht en zij een even bekwaam hoofd hadden bezeten als de Hollanders, er is geen twijfel aan of de vestiging van het Nederlandsch gezag op Java zou, minst genomen, geruimen tijd zijn vertraagd geworden. Maar dat alles liet veel te wenschen over. George Ball, hun opperhoofd te Bantam, was gebleken als koopman niet tegen Coen te zijn opgewassen, lag met Pring overhoop, en zorgde beter voor zijn eigen kas dan die der Compagnie. Dit laatste was een euvel, waaraan velen mank gingen; zelfs Dale had reeds vóór zijn vertrek eene vermaning van Bewindhebbers ontvangen omdat hij tegen zijn belofte voor eigen rekening waren insloeg ${ }^{2}$. Het schijnt dat de karige bezoldiging die de dienaren der Compagnie genoten daarvan de voorname oorzaak was. De kapiteins beklaagden zich dat Bewindhebbers het schuim van de natie in dienst namen om aan knappe zeelieden geen twee shillings meer te moeten betalen ${ }^{3}$. Bovendien werd er slecht gezorgd voor de uitrusting der schepen; de vloot van Dale, bij voorbeeld, leed een ontzachlijk verlies aan manschappen door bedorven mondkost. Voeg daarbij dat de Engelschen zelven erkenden veel meer behoeften te hebben dan de Hollanders en zich verbaasden dat dezen met zoo weinig tevreden waren ${ }^{4}$, en men zal zich minder verwonderen dat zij, zoo als wij nu zullen zien, van het behaalde voordeel zoo weinig partij wisten te trekken.

1 Coen bij De Jonge, IV, bl. 131 vv. Vgl. de Inleiding, bl. XCI-XCII.

2 Calendar, etc. II, No. 280.

3 Pring in Calendar, II No. 643.

${ }^{4}$ R. Fursland in Calendar III, No. 143, en elders. 


\section{TWEEDE HOOFDSTUK.}

Het Hollandsche fort te Djakatra door de Javanen en Engelschen belegerd (1619). Onderhandelingen civer de overgave. Bantam komt tusschenbeiden; verjaagt den regent uit Djakatra. De Engelschen vertrekken. De Hollanders behouden het fort. - Bestuur van Laurens Reael in de Molukken (1618-19). Tocht van Adam Westerwolt naar de Philippijnen. Coen komt Reael afhalen, vaart met de vloot naar Djakatra; verovert die stad (30 Mei 1619). De Engelsche vloot verlaat den Archipel. Onderhandelingen met Bantam. Verliezen der Engelschen. Terugkomst hunner vloot. Tijding van het accoord tussehen de Hollandsche en Engelsche Compagnie.

Toen Coen met de vloot naar Ambon vertrok bleven in 't onvoltooide Hollandsche fort te Djakatra 400 personen achter, waarvan 250, Hollanders en inlanders, de wapenen konden voeren. Zij waren wel voorzien van mondkost, maar zeer schraal van kruid, de voorname reden waarom Coen aan 't behoud van 't fort wanhoopte '. Tot commandeur was, zoo als wij zagen, Pieter van den Broecke aangesteld; als raad was hem toegevoegd de opperkoopman Pieter van Raey; een oud soldaat, die later als opperstuurman had dienst gedaan, Jan Jansz van Gorcum, had het bevel over de soldaten. $\mathrm{Na}$ Coen's vertrek werd het versterkingswerk voortgezet, en nu en dan werden van weerszijden eenige schoten gewisseld. Den 6 Januari 1619 kwam de Engelsche vloot ter reede van Djakatra en begaf Jourdain zich aan land om met den vorst te bespreken hoe men de bezetting van 't fort tot overgave zou dwingen. Beiden, de Engelschen zoowel als de Regent, vreesden dat de Bantammers er zich in zouden mengen, want niet alleen had reeds den 30 December een vloot van Bantamsche prauwen, volgens 't gerucht met 4000 koppen bemand, post gevat in de rivier van Angkee bewesten Djakatra, maar aan het Hof van den Regent bevonden zich verscheidene Bantamsche Edelen, zonder twijfel om hem op de vingers te zien 2.

1 Coen bij De Jonge, Inl. p. XCII.

2 Journaal van Pt. van den Broecke in "Begin en Voortgang der O. I. Comp." dl. II, bl. 89; Jourdain aan Dale, 31 Dec. (10 Jan.) in Cal. II, No. 524. Het verbond, dat de Engelschen volgens De Jonge p. XCV in December met Bantam 
Het schijnt dat de Regent de Engelschen aan de praat hield, totdat hij eerst nog een goede som van de Hollanders had afgetroggeld. Ongelukkig was van den Broecke, hoe ook door Coen gewaarschuwd, te argeloos om de streken der Javanen te doorzien. Hij liet zich met den Regent in onderhandelingen in ${ }^{1}$ en deze sloot met hem een bestand op voorwaarde dat hij hem 6000 realen zou uitkeeren. Intusschen was Thomas Dale aan land gekomen en had den Regent beloofd dat hij zijn geschut zou ontschepen om voor de verovering van het fort dienst te doen 2. Toen nu de Javaan het Hollandsche geld binnen had, liet hij van den Broecke dringend uitnoodigen hem een bezoek te brengen. Ook nu nog rook deze geen lont en was onverstandig genoeg om daaraan gehoor te geven ${ }^{3}$. Met den dokter, Hendrik de Haen, en vijf anderen begaf hij zich den 22 Januari naar het Hof van den Regent, maar nauwelijks traden de Hollanders den dalem binnen of zij werden door de Javanen overvallen en in de boeien gezet. Te laat begrepen de Hollanders dat men hen bedrogen had 4. In het fort werd nu weder met versterken voortgegaan. Maar ook de Javanen en Engelschen zaten niet stil. $\mathrm{Na}$ veel loven en bieden sloot de Regent met de Engel-

zouden gesloten hebben, berust op een misverstand. De Jonge heeft blijkbaar niet opgemerkt dat Bruce, op wiens gezag hij dit mededeelt, den Sultan van Bantam en den regent van Djakatra voor één persoon houdt, en dat bij hem van geen ander accoord sprake is dan van dat der Engelschen met Djakatra den 28 Januari 1619 ! Waarschijnlijk werd de Jonge in die dwaling gebracht door Coen, die meende dat de Engelschen "met gemeen advys en raedt van die van Bantam en Jacatra" handelden. Het tegendeel blijkt nu duidelijk uit de Engelsche documenten, doch indien de Jonge Van der Chijs (a. w. bl. 78) had nageslagen zou hij misschien reeds het rechte spoor gevonden hebben.

1 De Javaansche brieven van wegen den Regent naar 't fort gezonden kon niemand daar lezen; alleen de koksvrouw kon eenige woorden ontraadselen! Men begreep echter dat hij wilde onderhandelen en antwoordde hem in het... Chineesch! (MS. Journaal van Pt. Van den Broecke, fol. 69. Zie ook (A. Gijsels), Verhaal van eenige oorlogen in Indië, in Kronijk van 't Hist. Gen. 1871, bl. 549.

2 Calendar, II, No. 529; Pring bij Purchas, I b , p. 636.

$s$ Hij" beweert in zijn Journaal daartoe door den Raad geprest te zijn maar dit is onjuist. Zie de interrogatoriën van Juni 1619 op 't R. A. "Is geschiet doort 't hart aanraden van den Dr. de Haen ende op versoeck van den Commandeur V.d. B. selfs." (Antw. van Pt. van Raey). "Is ten deele syn eygen begeerte geweest." (Antw. van den assistent J. de Brasser). Van den Broecke zelf antwoordt "dat den Raedt sulcx goet gevonden (heeft en hy deposant niet dan zyn dienst om te gaen presenteerde."

4 Dat de Regent hierop het fort liet opeischen, zooals Coen vermeldt (De J. bl. 167) blijkt Inooh uit het Journaal van 't beleg noch uit dat van Van den Broecke. Deze zegt alleen dat de Regent hem een briefje aan die van 't fort liet schrijven het ongedateerde_briefje bij de Jonge, bl. 156 ?) 
schen een accoord waarbij de Hollanders van den handel werden uitgesloten. Het fort zou met behulp der Engelschen veroverd maar aan den Regent overgeleverd worden, nadat zij den buit onderling hadden verdeeld; de Hollandsohe bezetting zou op de Engelsche schepen naar de Kust van Koromandel worden overgebracht 1.

$\mathrm{Nu}$ werden aanstonds op het erf der Engelsche loge en elders batterijen aangelegd en met Engelsch geschut voorzien, en een brug over de rivier gelegd om het fort te bestormen 2. Den 29 Januari zond Dale een brief aan de bezetting waarbij hun bij overgave lijfsbehoud werd toegezegd. Ook werden van den Broecke en zijne medegevangenen gebonden naar de stadsmuur gebracht om hunne landgenooten te vermanen met den Engelschen generaal in accoord te treden ${ }^{3}$. Pieter van Raey, die thans in ' $t$ fort bevel voerde, liet hierop den Raad bijeenkomen. Men overwoog dat het fort een beleg niet lang zou kunnen uithouden, daar er zeer weinig kruid in voorraad was, en besloot dus den kapitein van Gorcum naar Dale af te vaardigen om goede voorwaarden te bedingen. Den 31 Januari werden die voorwaarden tusschen Dale, den Regent en de Hollanders vastgesteld. De Regent zou de gevangenen vrijlaten en dezen zouden zich met de geheele bezetting op de Engelsche schepen begeven om naar de kust van Koromandel te worden gebracht, na zich verbonden te hebben tot November van dit jaar niet tegen de Engelschen te dienen. Alle geld en goed, dat aan de Compagnie behoorde, moest aan den Regent worden uitgeleverd 4.

De Hollanders maakten nu aanstalten om te vertrekken, maar tot hun geluk kwam er op het laatste oogenblik, zoo als een hunner het juist uitdrukte, " een spaak in 't wiel."

Yangeran Aria Manggala, de rijksbestuurder van Bantam, begreep dat het tijd werd tusschenbeiden te komen. De geldzucht van Bantams leenman, den Regent van Djakatra, was reeds oorzaak geweest dat de Hollanders zich daar hadden versterkt, en nu er groote kans bestond dat zij hun fort verlieten zouden de Engelschen er zich

1 Calendar, II, No. 538, 546, 609; Pring bij Purchas, I b, p. 636; John Bruce, Annals of the East-India Company (London 1810), vol. I, p. 210-11.

2 Journaal bij de Jonge, IV, p. 141, 142.

3 De Jonge heeft uit de stukken bewezen (wat Van der Chijs reeds vermoedde) dat Van den Broecke's memorie te kort is geschoten toen hij meende, op den muur staande, de bezetting te hebben toegeroepen om standvastig te blijven.

4 Journaal bl. 144, 145; Van den Broecke bl. 94; Van der Chijs bl. 212-14; Bruce p. 211. 
misschien nestelen! Men zou dan van het eene kwaad in het andere vervallen. Het was in het belang van den Pangeran, geen van beide natiën van zich te vervreemden, daar juist hun mededinging hem groote voordeelen verschafte, maar ook geen van beiden te veel voet te geven. Daarom had hij na de komst van Dale en vooral na het verbranden van de Engelsche loge te Djakatra door Coen, toen de Hollandsche loge te Bantam gevaar liep door de Engelschen vernield te worden, de Hollanders gewaarschuwd en beschermd '. Toen hij nu vernam wat tusschen de Engelschen en den Regent van Djakatra gebrouwen werd, liet hij in allerijl 3 of 4000 man in prauwen daarheen vertrekken en gaf aan Augustine Spalding, het hoofd der Engelsche factorij te Bantam te kennen dat niet de Engelschen over Djakatra te beschikken hadden maar de Sultan van Bantam 2. Dat hij door de Hollanders te Bantam op het denkbeeld werd gebracht om van den Broecke en de zijnen van den Regent van Djakatra op te eischen ${ }^{3}$ onder belofte dat zij aan hem het fort zouden overleveren, is mogelijk; in elk geval ze werden door hem opgeeischt, en daardoor waren de Engelschen verhinderd aan eene der eerste voorwaarden van de capitulatie te voldoen 4. Van Raey en de zijnen stonden reeds gereed zich aan boord van de Engelsche schepen te begeven, maar toen zij vernamen dat van den Broecke en de zijnen niet waren vrijgelaten en bespeurden dat de Bantamsche vloot den mond der rivier versperde, vreesden zij voor verraad en weigerden het fort te verlaten. Ook Dale schijnt op dit machtsvertoon van Bantam niet voorbereid geweest te zijn en achtte het ongeraden den Pangeran openlijk te trotseeren met het oog op het volk en de goederen in de loge te Bantam. Ook vreesde hij dat de Javanen zich van zijn geschut, dat aan land gebracht was, zouden meester maken en gaf bevel dit onmiddellijk weder in te schepen $\mathbf{5}$.

De Engelschen stelden nu nog wel pogingen in het werk om de Hollanders tot overgave van het fort te bewegen, en een deel der bezetting verkoos dit boven overgave aan de Javanen, maar daar zij volstrekt geen zekerheid hadden dat de Engelschen hen op hun schepen

1 Coen bij De Jonge 123, 172; MS. Journaal Van den Broecke.

2 Spalding aan Dale in Calendar II No. 518, welk stuk verkeerd gedagteekend is 26 December (5 Januari) in plaats van 26 Januari (5 Februari). Zie ook No. 562, dat wel een afschrift van 't zelfde stuk schijnt te zijn.

${ }^{3}$ Coen bij de Jonge IV bl. 172.

4 Dale in Calendar Il, No. 609; Journaal bij de Jonge IV, bl. 145 onderaan.

${ }^{5}$ Calendar, No. 562, 563. Vgl. Journaal bij De Jonge, bl. 146, 147; en (A. Gijsels), Verhaal in Kronijk Hist. Gen. 1871, bl. 554. 
kònden brengen zonder dat de Bantammers, die Dale niet met de wapenen wilden weerstaan, dit beletten, moesten zij de onderhandelingen wel afbreken 1.

Intusschen bood ook de Pangeran van Bantam de Hollanders gunstige voorwaarden aan, indien zij 't fort aan hem overgaven. In weerwil van den tegenstand van 't garnizoen werd door den Raad daartoe besloten. De kooplieden uit Bantam die hun de voorwaarden gebracht hadden werden teruggezonden om met den Pangeran in accoord te treden. Doch nog vóór zij waren teruggekeerd brachten de Bantammers te Djakatra een anderen last van hun Sultan ten uitvoer. In den nacht van 15 op 16 Februari begaf hun tumenggung 2 zich met een talrijk gevolg van gewapenden naar het Hof van den Regent, trad op hem toe en zette hem de kris op de borst met bedreiging hem te doorboren, indien hij niet dadelijk afstand deed van de Regeering. De zwakke Widjaja Krama schijnt bij zijne onderhoorigen geen hulp gevonden te hebben; althans den volgenden dag nam hij met een vijftigtal volgelingen de wijk naar het binnenland 3. Van nn of verdwiint njin naam vit de geschiedenis.

De Hollandsche kooplieden te Bantam waren niet zoo haastig als die te Djakatra. Zij stelden als voorwaarde voor de overgave van het fort dat de Rijksbestuurder aan de Engelschen een vrijpas zou vragen, want ook op zijne belofte van bescherming tegen de Engelschen meenden zij niet te kunnen vertrouwen. De Pangeran begreep wel dat de Engelschen, die hij bedrogen had, hem dien vrijpas niet zouden geven, en dreigde nu, als de Hollanders hem het fort niet overgaven, dat hij er hen met de hulp der Engelschen toe zou dwingen. Gelukkig begreep nu toch ook de bezetting van het fort dat zij het verstandigst zou doen geen der beide partijen te vertrouwen en te blijven waar zij was zoo lang zij zich nog kon verdedigen. $\mathrm{Zij}_{\mathrm{ij}}$ besloot dus den 26 Februari de voorstellen van Bantam af te slaan, 4

De Pangeran schijnt werkelijk gemeend te hebben dat hij de Engelschen nog als zijn speelbal kon gebruiken. Maar hierin werd hij toch teleurgesteld. Dale was na den mislukten aanslag op het fort te Djakatra en de vergeefsche onderhandelingen met de bezetting, met zijne vloot naar Bantam teruggekeerd. Hier vernam hij nu

1 Calendar, No. 568, 569, 571; Journaal bij De Jonge bl. 147; Coen ald. bl. 173.

2 Was hij door den Sultan tot tumenggung van Djakatra aangesteld?

3 Journaal bij De Jonge, bl. 150; Coen ald. bl. 174. Van den Broecke, bl. 95.

4 Journaal bij De Jonge bl. 151; Coen ald. bl. 173, 174. - Voor de verdere onderhandelingen met Bantam zie men Van der Chijs, a, w. bl. 123 vv. 
dat de Hollanders besloten hadden zich aan den Pangeran over te geven, en dat de Bantammers Djakatra reeds bezet en den regent verjaagd hadden. De "duivelsche politiek" van den Javaan, die zich nu weer tot de Hollanders genegen toonde en de Engelschen op alle wijzen tegenwerkte, boezemde hem zooveel wantrouwen in dat hij bevel gaf Bantam te verlaten en de goederen weder in te schepen. De Pangeran liet er zich eerst weinig aan gelegen liggen, maar toen hij het besluit der Hollanders vernam om in hun fort te blijven begon hij aan Dale weder voorstellen te doen. Dale vertrouwde hem echter niet en bleef bij zijn besluit. In de Engelsche faktorij bleven slechts 4 personen achter 1 .

Even ongelukkig als in hun streven om de Hollanders te Djakatra den voet te lichten waren de Engelschen in hunne pogingen om zich van de schepen van den vijand, die van elders verwacht werden, meester te maken. Het schip de Zwarte Leeuw was door onvoorzichtigheid van de Engelschen zelven met lading en al verbrand. Twee jachten uit Djambi kwamen den 3 Maart ongehinderd te Djakatra; het eene werd onmiddellijk naar Ambon gezonden om Coen van 't voorgevallene kennis te geven; het andere voor dat de Engelschen er bij kwamen in brand gestoken. Den 8 Maart ontvingen dezen de tijding van de Portugeezen, die in den laatsten tijd weder met Bantam in betrekking zochten te komen 2, dat vier Hollandsche schepen bij Straat Sunda gezien waren. Martin Pring voer hen met een gelijk getal schepen te gemoet. Den 11 Maart vond hij hen voor anker bij het eiland Tampurang aan den mond der zeestraat en tastte hen aan, maar de Hollanders wisten hem te ontkomen. Dale voer toen met vier schepen uit om hen te vervolgen maar was door storm genoodzaakt terug te keeren. De Hollanders kwamen behouden te Ambon om zich met Coen's vloot te vereenigen 8.

$\mathrm{W}_{\mathrm{ij}}$ zouden meer moeten weten van de Javaansche toestanden in dezen tijd, van de verhouding bij voorbeeld tusschen den rijksbestuurder van Bantam en de partij die liever het bewind in handen zag van den jongen Sultan, om met eenige zekerheid over de gedragslijn van den eerste te kunnen oordeelen. Uit Hollandsche berichten vernemen wij dat hij, tegen den wensch van den Sultan

1 Calendar, II, p. 254, 266, 267; Pring bij Purchas, p. 636.

2 Vgl. Coen bij De Jonge, p. 136.

3 Calendar, II, No. 603, 607, 609, 614, 643; Pring bij Purchas, I b, p. 636, 637 ; Hatch, aldaar p. 620; Journaal bij De Jonge, bl. 152-53; Coen ald. 175; Coen in Dodt's Archief, VII, bl. 205, 206. 
en van alle Bantamsche grooten in, de Hollanders in het fort te Djakatra met vrede liet. Het is moeielijk aan te nemen, dat hij zich door de laatsten met onderhandelingen aan de prat had laten houden als hij werkelijk den wil en de macht had gehad zich van het fort meester te maken; evenmin dat hij, door de verzekeringen van van den Broecke misleid, van Coen onderwerping verwachtte, indien hij het fort slechts spaarde tot diens komst. Ik vermoed dus dat hij uit vrees voor een verbond tusschen de Hollanders en den vorst van Mataram, dat voor Bantam zonder twijfel noodlottig zou geweest zijn, de eersten niet tot het uiterste wilde drijven. Er kan nog een ander motief in 't spel geweest zijn. De Engelschen zagen hem voor hun persoonlijken vijand aan en stookten den Sultan tegen hem op, meenende door zijn val hun doel te kunnen bereiken ${ }^{\mathbf{1}}$; de Hollanders daarentegen eerbiedigden hem als het hoofd der Regeering. Misschien was het dus in zijn persoonlijk belang de laatsten te steunen.

Met dat al blijft het altijd mogelijk dat alle pogingen der Javanen om het fort te veroveren zonder hulp van Europeesch geschut toch vergeefs zouden geweest zijn.

Hoe dit zij, wij kunnen veilig aannemen dat verdeeldheid onder de Bantamsche hoofden de voorname oorzaak was dat zij niet met kracht tegen de Hollanders optraden. In 't begin van April begonnen zij wel de batterijen tegenover het fort, die door de Hollanders, na hare ontruiming door de Engelschen, vernield waren, weder te herstellen - uit vrees voor een aanval van den vorst van Mataram, heette het - maar het kostte de bezetting geen moeite die ten tweeden male te vernielen. Want hoewel de kooplieden, van den Broecke en de anderen die te Bantam in bewaring bleven, er op aandrongen den Pangeran, die hun welgezind was, niet verder te verbitteren, begreep de kapitein, Jan Jansz. van Gorcum, dat hij, door zich ferm te houden en geen vrees te toonen, de Javanen meer ontzag zou inboezemen dan door hen schroomvallig te ontzien 2.

$\mathrm{Na}$ den laatsten uitval bleven dan ook van weerszijden de wapenen rusten, en dit had een maand lang geduurd toen den $10 \mathrm{Mei}$ een prauw waarin Hollanders gezeten waren zich aan den mond der rivier van Djakatra vertoonde. Met groote vreugde zag de bezetting die prauw naar het fort toekomen en de raden van Indië Pieter de Car-

1 Calendar II, p. 267; Purchas I b, p. 637.

2 Zie Van der Chijs, a. w. bl. 166. 
pentier en Andries Soury aan wal stappen. Zij waren met het fregat Ceylon, dat in de nabijheid lag, de vloot van Coen vooruitgezeild en brachten de welkome tijding dat deze in aantocht was.

Wij hebben Coen verlaten toen hij met zijn kleine eskader de Engelschen ontzeilde. Met vier schepen kwam hij den 4. Februari 1619 te Ambon; de overigen had hij onderweg naar Gresik, Solor en Bima gezonden om verversching te halen 1. Coen vond op Ambon "alles in een zeer goeden stand door den moed en den ijver van den Luitenant-gouverneur van Speult", dien hij dan ook niet aarzelde in zijn ambt te bevestigen en tot Raad van Indië te benoemen. Wij zullen later zien dat de invloed van Coen op van Speult niet gelukkig is geweest.

Coen vertoefde enkele dagen op Ambon, daar het gerucht liep dat in den omtrek Engelsche schepen gezien waren. Toen het bleek dat dit Hollandsche schepen waren, begaf hij zich naar de Molukken en kwam den 9 Maart voor Batsjan ten anker.

In Juli 1618 zagen wij Reael van Banda in de Molukken terugkeeren. Sedert was daar weinig veranderd. Kort voor zijn terugkomst had een Engelsch schip 2 Tidore aangedaan en met de Spanjaarden geschut en rijst geruild voor nagelen, zonder dat de Hollanders dit konden beletten. $\mathrm{Na}$ het gebeurde in Banda was het geen wonder dat de Engelschen, waar zij kwamen, de inlanders tegen de Hollanders opzetten ${ }^{3}$. Van Spaansche zijde ontbreken uit dezen tijd bijna alle berichten. Wij weten slechts dat Luca de Vergara hier het bewind voerde en eene compagnie soldaten en alle gehuwde Portugeezen naar Manila had moeten zenden; hij hield echter manschappen genoeg over om nieuwe versterkingen op Tidore en Ternate aan te leggen,

1 Zie voor het volgende den brief van Coen van 5 Augustus 1619, waarvan Van der Chijs en De Jonge alleen het gedeelte overnamen dat op Java betrekking had. Het was hun ontgaan dat de geheele brief reeds was afgedrukt in Dodt's Archief voor kerkelijke en wereldlijke geschiedenis enz. van Utreeht, dl. VII (Utrecht 1848), bl. 195 vv., doch zeer slordig. Op bl. 195, reg. 14 v. b. leze men Bima voor Banda; op bl. 196 tweemaal Boano voor Bouro, op bl. 199, reg. 5 v. o. provisie voor finantie; op bl. 200 , reg. 9 v. o. 23 Maart voor 21 Maart; op bl. 201 , reg. 2 v. 18 Mey voor 18 Maart, enz. Bladz. 219 , reg. 14 v. b. zijn na 't woord Atchyn uitgevallen de woorden nbetaelt was, is daer over groote menichte van peper van Ticco na Atchijn", en moet 5 regels lager gelezen worden: "wat wint die man... in 't hooft heeft."

2 De Thomas onder John Millward in 1614 van Engeland uitgevaren. Zijn journaal (bij Purchas I b, 524 vv.) gaat zoover niet.

3 Ad. Westerwolt aan Bewindh., 8 Aug. 1618. 
ten einde den vijand het nagelplukken te beletten en den toevoer tusschen de forten te bemoeielijken. Reael meende nu het dringend verzoek der Ternatanen niet te mogen afslaan, tot het bouwen van een nieuw fort te Kalamata, dat den vijand in bedwang hield '. Op zee hadden de Spanjaarden en Tidoreezen de overhand door hunne fregatten en korakora's, daar het de Hollanders aan klein vaartuig ontbrak. Geen wonder dat de Ternatanen gebrek leden en de Hollanders verwenschten, die hen niet van leeftocht voorzagen. Reael, van der Haghen, Lam, mannen van beteekenis, die zich thans in de Molukken bevonden, waren dan ook eenstemmig in hun afkeuring van de politiek der Bewindhebbers, die maar hardnekkig bleven aandringen op het weren van de inlandsche handelaars, uit vrees dat deze nagelen in ruil zouden bekomen. Nagelen kregen de Hollanders nu toch niet 2. De kleeden, die zij noodig hadden, moesten zij hun te duur betalen om de moeite van het nagelplukken "dat travailleus en periculeus is " te beloonen. Ook waren zij nu gedwongen zelven rijst te bouwen door de groote duurte der sagu, die zij vroeger van de Javanen kochten en nu vijf of zesmaal duurder aan de Hollanders moesten betalen of zelven van verre halen ${ }^{3}$. Toen Reael dit schreef, was de tijding nog niet tot hem gekomen dat Coen in zijne plaats was benoemd en Bewindhebbers dezen verzocht hadden zijn voorganger niet langer in dienst te houden, maar hem "met de eerste schepen over te zenden." Had hij dit geweten, hij zou zich misschien de moeite niet gegeven hebben bij Bewindhebbers op verandering hunner politiek ten opzichte der inlanders aan te dringen. Hij wist te goed dat van Coen die verandering niet te wachten was.

In 1618 had Reael weder aan den wensch van Bewindhebbers, om de vaart der Chinezen op Manila te bemoeielijken, gevolg gegeven, en den 24. Augustus vijf schepen onder aanvoering van Adam Westerwolt (directeur van den handel in de Molukken) naar Luçon gezonden. Coen zelf had daartoe aangespoord ${ }^{4}$, en Reael en zijn raden achtten het oogenblik daartoe des te geschikter toen zij vernamen dat de Spanjaarden in de Philippijnen door het verongelukken hunner

1 Resol. Ambon, 10 Dec. 1618; Lam aan Bewindh. 14 Aug. 1619; vgl. Calendar, II, p. 385. Kalamata lag op Ternate, niet op Tidore zoo als Coen schrijft.

2 Wij zullen later zien dat dit de Bewindhebbers onverschillig was, als anderen ze maar niet kregen.

s Reael aan Bewindh., 20 Aug.; Van der Haghen aan dez. 20 Aug.; Lam aan deze 14 Aug. 1619. Vgl. ook Aert Gysels, in Kronijk Hist. gen. 1871, bl. 507-9.

4 Zie mijn Achtste gedeelte, bl. 325. 
vloot zeer verzwakt waren 1. In Juli was de opvolger van Silva, Don Alonso Fajardo, met een enkel schip te Manila aangekomen, want de Koning van Spanje had te veel geld en troepen noodig om het Huis van Oostenrijk in Duitschland hulp te kunnen bieden, dan dat hij aan Manila kon denken.

Westerwolt had weinig voorspoed op zijn tocht. Hij leed gebrek aan mondkost en moest twee van zijn schepen, die niet meer zeewaardig waren, sloopen. Slechts drie jonken vielen hem in handen. De Chineezen waren bij tijds gewaarschuwd en bleven meerendeels weg. Twee schepen voeren toen naar Japan om provisie voor de Molukken te halen, en met het derde kwam Westerwolt in December 1619 te Djakatra 2.

Westerwolt was dus met zijn eskader afwezig, toen Coen te Batsjan aankwam, en daar op de komst van Reael bleef wachten omdat de moesson hem tegen was. Hij vernam dat Reael en Vạn der Haghen op Makian ziek lagen, maar weinige dagen later waren zij toch zoover hersteld dat zij zich bij Coen konden vervoegen ${ }^{3}$ die toen onmiddellijk met hen naar Ambon terugkeerde. Coen had tegenover Reael de beleefdheid om eerst den $24 \mathrm{Juli}$, den dag waarop deze als Gouverneur-Generaal moest aftreden, vast te stellen voor de proclamatie van zijn opvolger.

$\mathrm{Na}$ Coens terugkomst te Ambon (20 Maart) liepen daar langzamerhand ook de uitgezonden jachten binnen. Te Gresik, waar de Hollanders tot groote blijdschap van den vorst van Surabaja in 1618 waren teruggekeerd en zoowel peper als levensmiddelen opdeden ${ }^{4}$, was Coens gezant, W outer Heuten, die den vorst een stuk geschut en eenige kleeden aanbood, zeer eervol ontvangen. De vorst had in persoon zijn schip bezocht en de Hollanders bizondere gunst bewezen $\mathbf{5}$. Zonder twijfel hoopte hij op hun bijstand tegen den vorst van Mataram.

Met advies van Reael en Van der Haghen werd thans de raad

1 Zie mijn Achtste gedeelte, blz. 324.

${ }^{2}$ Lam aan Bewindh., 14 Aug. 1619; Coen aan dez. 22 Jan. 1620. Vgl. Van Dijk, Neerlands vroegste betrekk. met Borneo enz. (Amst. 1862) bl. 233-35; Juan de la Concepcion p. 456-58; Brief van Luca de Vergara achter de "Relation des Philippines" bij Thévenot.

3 De voorstelling bij Van der Chijs (a. w. bl. 179) alsof Reael Coen lang liet wachten is in strijd met Coen's eigen berioht. Coen had slechts één schip bij zich, Reael ook een.

4 Coen aan Bewindh., 24 Juni, 26 Juli 1618.

5 Coen bij De Jonge, bl. 205. 
van Indië met vijf personen aangevuld 1 en den 23 Maart nam deze het besluit "met de macht die zij op 't spoedigste konden bijeenverzamelen zich te begeven naar de Engelsche vloot, om zich daarvan, en van alle Engelsche schepen die zij ergens aantroffen, meester te maken, onder behoorlijken inventaris, om daarvan rekening te doen daar't behoort, daar men geen ander middel weet te bedenken om den Indischen handel in stand te houden." De Breede Raad van kooplieden, schippers en officieren bevestigde dit besluit en ieder verbond zich bij eede het na te komen. Coen was zeer verblijd thans geen tegenstand te ontmoeten, waar het gold forsche maatregelen tegen de Engelschen te nemen.

Den 5 April 1619 voer hij met 11 schepen naar 't "rendez-vous" bij Madura. Onderweg deed hij Buton aan om de vloot te ververschen, maar de radja was blijkbaar niet op zijn gemak over al die schepen, zoodat men " om occasie van questie, die sich begonst te verthoonen, te schouwen" maar spoedig vertrok. Reael nam nu met vier schepen een korten omweg over Makassar om te zien of hij daar buit kon maken 2. Slechts een Portugeesche jonk viel hem in handen; toen hij een andere, die aan 't strand lag, wilde bemachtigen, werd hij zoo hevig beschoten dat hij het opgaf en naar de vloot terugkeerde.

Den 14 Mei had Coen bij Madura 16 schepen en een jacht bijeen. De slagorde werd nu vastgesteld als men de Engelschen mocht ontmoeten en hierop voer de vloot de Javaansche kust langs. Te Djapara zag men de Engelsche vlag van de loge waaien, en besloot tot een landing. Daar de stad eenigszins versterkt was en de Javanen tegenstand boden, werd zij voor de tweede maal in de asch gelegd, met eenige jonken die op de reede lagen 3.

Voor Djapara vernam Coen waar de Engelsche vloot zich ophield. Zij lag in Straat Sunda en zou van plan zijn de Hollandsche sche-

1 Pieter de Carpentier, Arent Maertsen, Willem Jansz, Andries Soury en Herman van Speult (reeds vermeld).

2 Coen had daartoe Arent Maertsen last gegeven, doch deze overleed onderweg, den 25 April. Het was dezelfde Arent Maertsen (niet A. Mz. Blocq zoo als De Jonge zegt: IV, bl. CXLIII), die in last had na in November 1618 Djapara beschoten te hebben, hetzelfde te Makassar te doen. Dat hij daar toen geweest is met 3 schepen vind ik alleen vermeld door Courthope (bij Purchas I b, p. 675) uit een brief van Thomas Staverton, Engelsch factor te Makassar. Deze verhaalt dat de Hollanders den Koning voldoening vroegen over den moord aan hun landgenooten gepleegd, dat er over en weer brieven werden gewisseld, en dat zij eindigden met het verbranden van een Javaansche jonk. Zie ook Staverton in Cal. II, No. 736 .

3 Corn. Gerritsz Verloren Arbeyt aan Bewindh., voor Djakatra 4 Aug. 1619; Coen bij De Jonge, p. 163, 164. 
pen niet af te wachten, maar dadelijk verder te gaan. Te Djakatra zou men dus niet met hen te rekenen hebben. Op voorstel van Coen werd nu door den Raad besloten die plats tot een algemeen rendez-vous in te richten en, om te beginnen, de Javanen uit de stad en den omtrek te verdrijven. Den 28 Mei zag Coen zijn stichting weder. Het volk werd nu van de schepen naar het fort overgebracht en den 30 met duizend man, meest matrozen, de stad aangetast. Hoewel de Bantammers omtrent 3000 man sterk waren, boden zij weinig tegenstand en waren spoedig verdreven. De inwoners hadden reeds de vlucht genomen '. De geheele plaats werd in de asch gelegd en de muren geslecht. Djakatra had opgehouden te bestaan. Op haar puinhoopen verrees weldra een nieuwe stad die den naam zou ontvangen van Batavia ${ }^{2}$. Wij zullen haar voortaan met dien naam aanduiden.

Twee dagen later werden de Javanen, die zich in den omtrek versterkt hadden, ook van daar verdreven en al de woningen aan de rivier tot op een half uur afstands verbrand. "In dezer voegen" schreef Coen aan Bewindhebbers, "hebben wij voet en dominie in 't land van Java bekomen." Dat de omstreken nog geruimen tijd voor de Hollanders onveilig bleven, spreekt van zelf.

Wij hebben de Engelschen verlaten, nadat zij in onmin met den Pangeran, hun volk en goederen uit de loge te Bantam weder hadden ingescheept. Het kon hun niet lang verborgen blijven dat Coen met een grooter vloot dan de hunne in aantocht was; met hunne slecht uitgeruste en zwak bemande schepen achtten zij het niet geraden hem af te wachten. In 't begin van April besloten zij dus met de vloot naar de kust van Koromandel te zeilen om zich daar van het noodige te voorzien en op het eind van Augustus naar den Archipel terug te keeren, waar zij dan een beter uitgeruste vloot uit Engeland hoopten te vinden om gezamenlijk de Hollandsche slag te leveren, tenzij intusschen tot de vereeniging van beide compagniën besloten was, waarover men wist dat in Europa onderhandeld werd, en wat vele Engelschen van harte wenschten 3. Of 'nu John Jourdain, de

1 De bewering van Crawfurd dat een deel der inwoners "were put to the sword" is reeds door Van der Chijs tegengesproken. Er werden slechts 9 dooden gevonden.

2 Zie over de naamgeving: De Jonge, IV. Inl. bl. CXXXVII. Het besluit van 1617 komt niet in de Resolutien van Bewindh. voor maar in hun brief aan Gouv.Gen. en Raden van 31 October.

${ }^{3}$ Pring in Calendar II, p. 266, 267, 299, en bij Purchas I b, p. 637. 
"president" of directeur van den handel, die met den bevelhebber der vloot Thomas Dale overhoop lag over het gezag dat hun beiden toekwam, dit voornemen om den Archipel te verlaten afkeurde 1 is ons niet bekend; wij weten alleen dat hij zich ter kwader ure met twee schepen van de vloot afscheidde om de factorijen te Djambi, Patani en elders te gaan bezoeken. Met de overige elf schepen gingen Dale en "Pring in 't begin van Mei van Bantam onder zeil en namen drie Chineesche jonken mede, die zij in Straat Sunda, zoo het heette op afrekening der Bantamsche schulden, van alles beroofden 2. Den 31 Mei voer Pring met vijf zeilen vooruit naar de kust van Dekhân, terwijl Dale met de overigen een poging deed om nog iets machtig te worden van een zijner schepen, dat bij zijn komst aan de kust van Engano gestrand was. Een enkelen bodem liet men te Tiku achter om de schepen die verwacht werden te waarschuwen dat zij niet verder zouden gaan 3 .

Pring kwam in ' $t$ begin van Juli te Masulipatam, en Dale, wiens pogingen te Engano vergeefsch geweest waren, in 't laatst van dezelfde maand. Dale, die reeds ernstig ziek was toen hij Bantam verliet, overleed hier den 19 Augustus. Het duurde tot 20 December eer de Engelsche vloot zich weder op weg begaf naar den Archipel. Dit langdurige oponthoud werd weder aan tuchteloosheid van het scheepsvolk toegeschreven. Zij wilden niet eer vertrekken voor de buit uit de Chineesche jonken te gelde was gemaakt. Ook ontging Pring na zijn terugkeer in Engeland te nauwernood een gerechtelijke vervolging 4 .

Des avonds na de verwoesting van Djakatra had Coen reeds een prauw naar Bantam gezonden om de Hollandsche gevangenen van het gebeurde kennis te geven en hen te gelasten dit ook aan den Pangeran mede te deelen, met bijvoeging dat hij van plan was met de vloot naar Bantam te zeilen en er op rekende dat hem de gevangenen aan boord zouden gezonden worden. Er heerschte te Bantam zoo groote ontsteltenis over de verovering van Djakatra dat het Coen misschien weinig moeite zou gekost hebben zich ook van die stad meester te maken s, maar hij meende dat "die peer nog niet rijp

1 Vgl. Calendar II, No. 644, 761, 846, 908.

2 Pring bij Purchas, Ib, p. 637; Calendar II, No. 775.

3 Calendar II, ${ }^{,}$No. 670.

4 Calendar: II, No.\$1133, 1134, 1136, 1138, 1161.

Zie Calendar II, p. 405. 
was." De Pangeran deed wat hij kon om de stad in staat van tegenweer te stellen en ontbood alle beschikbare hulptroepen uit het binnenland en de Lampongs. Den 8 Juni kwam de Hollandsche vloot voor Bantam. De Pangeran wilde nog voorwaarden stellen voor hij de gevangenen uitleverde, maar toen Coen met bedreigingen antwoordde liet hij hen gaan.

$\mathrm{Nu}$ scheen Aria Manggala weder gezind met de Hollanders handelsbetrekkingen aan te knoopen. Coen wilde niets liever, en liet geld en goederen aan land te brengen, maar het bleek spoedig dat het vertrouwen der inlanders geweken was. Van den handel kwam niets, omdat de Pangeran niet dezelfde vrijheden wilde toestaan als voorheen, en de Hollanders werden streng bewaakt. Toen dit eenigen tijd geduurd had - Coen was inmiddels met de vloot naar Djakatra teruggekeerd en had drie schepen voor Bantam achtergelaten - begonnen deze zonder den Pangeran vooraf te waarschuwen eenige jonken aan te halen. Dit was niet geschikt om den toestand te verbeteren, en den Pangeran welwillender te stemmen, en op de vraag van Coen wat hij wilde: vrede of oorlog, gaf hij een onverschillig antwoord. "Wat de Hollanders wilden dat wilde hij ook." Nu werd de blokkade van Bantam met kracht doorgezet. Niet alleen van de handelsvaartuigen die zich naar de stad begaven maar ook van de Bantamsche visschersprauwen maakten de Hollanders zich meester. De Pangeran nam echter geen weerwrak op de Hollanders in de loge, maar liet hen met hunne goederen aan boord hunner schepen brengen, en aan Coen zeggen: als hij vriendschap begeerde, dan moest hij iemand zenden, en hem anders met vrede laten. Coen wachtte eerst of hij zelf aanbiedingen zou doen, maar zoover wilde de Javaan zich niet vernederen; er bleef nog altijd kans op medewerking van de Engelschen en ook met de Portugeezen te Malaka werden door hem onderhandelingen gevoerd. Eindelijk deed Coen in 't belang van den handel - want er lag een groote voorraad peper te Bantam weder vredesvoorstellen. Maar de zekerheid om vrij te mogen handelen, zonder dat aan de Chineezen of anderen eerst werd toegestaan de peper op te koopen en den prijs te dwingen, kon hij niet verkrijgen. Ten laatste maakte de Pangeran zelf een einde aan de onderhandelingen door Coen te laten weten dat hij, zoowel als alle Bantammers, vrede wenschte, maar er stond één zaak in den weg, en Coen wist wel wat dit was. "Djakatra is het", schreef Coen aan Bewindhebbers, "dat de Pangeran begeert en hem in den weg staat. Hij zou er wel $\$ 00,000$ zakken peper voor geven, maar 
het behoud van een algemeen rendez-vous is meer waard dan dat." I

Inderdaad liet het zich aanzien dat Batavia weldra een aanzienlijke handelsplaats zou worden. De Pangeran had wel aan Javanen en Chineezen op doodstraf verboden daarheen te gaan, en ook elders op Java werd dit zoo veel mogelijk belet, maar het baatte weinig toen zij bespeurden dat er voordeel te behalen was. Het duurde niet lang of eenige honderden Chineezen hadden er zich gevestigd en de Javanen kwamen er in menigte met hunne prauwen levensbehoeften brengen. Coen liet nu ook met het bouwen van een nieuw fort een aanvang maken, maar het ontbrak hem nog aan genoegzame werkkrachten. Hij drong er bij Bewindhebbers op aan dat zij gehuwde handwerkslieden en soldaten zouden overzenden, en vooral met het oog op de toekomst jongens en meisjes, maar van de laatsten alleen "onderjarige", daar de proef die men met de "bedaagde" had genomen zoo slecht was uitgevallen. ${ }^{2}$ Tot versterking van de garnizoenen liet hij uit Japan soldaten komen. ${ }^{3}$

De redenen die Dale bewogen om de Hollandsche vloot niet af te wachten, zullen wel overwegend zijn geweest, maar indien hij in den archipel gebleven was, had hij althans de schepen die zich daar nog bevonden kunnen beschermen. Thans vielen dezen bijna allen aan de Hollanders in handen. De beide schepen van Jourdain hadden Djambi bezocht en lagen thans voor Patani. Coen zond er drie

1 Coen bij De Jonge IV, bl. 117-184, 188, 193, 196; Coen bij Dodt bl. 231; MS. Journaal van Van den Broecke f. 75 vv.; Coen aan Bewindh. 11 Mei 1620.In hoever de Pangeran van Bantam of de ex-regent van Djakatra oorzaak waren van een aanslag op het leven van Coen in October 1619 (zie Coen bij De Jonge, bl. 191 , 192 en vgl. de Inleiding bl. CXVI) is moeielijk uit te maken. De schuldigen werden veroordeeld om geradbraakt te worden, maar "den Ed. Heer Generaal . . . heeft door sonderlinge clementie en genade de sententie . . belieft te versachten en dat sy levendich aen een pael geworcht, daer naer 't hooft affgeslagen, haer lichamen gequartiert en op staken gestelt sullen worden." (Resol. van 22 Oct. 1619).

2 Coen bij De Jonge IV, bl. 190, 197, 201, 206, 207. - "Wy bevelen u", schreef Coen aan den Raad van Ambon (20 Februari 1619) "de gedebaucheerde ofte onstichtich ende ontuchtich-levende Nederlantsche vrouwen met eerste gelegentheyt naer Java te senden omme van daer voorts naert Patrya versonden te werden." Toch ontving hij later weer een dergelijke bezending. "Voorwaer", schreef hij an Bewindhebbers (6 Sept. 1622), "'t is een groote schande en verachtering van de gemeene welstant dat weder op nieuws oneerlijke vrouwen gesonden hebben. Hier te lande zijn hoeren genoech".

1 Den 22 Jan. schreef hij aan Bewindh. dat er reeds 90 gekomen waren, maar den 8 Mei 1621 berichtte hij hun dat "de Keizer verboden had Japanners ten oorlog uit te voeren." 
schepen op af onder Hendrik Jansz, den gewezen gezagvoerder op de Zwarte Leeuw, die het verlies van zijn schip op de Engelschen te wreken had. Den 27 Juli kwam hij voor de stad, viel de Engelsche schepen aan en teisterde ze zoodanig dat Jourdain den strijd moest opgeven en zijn schipper naar Hendrik Jansz zond om voorwaarden te bedingen. Terwijl dit plaats had, werd Jourdain, zoo 't schijnt door een schot uit een der andere schepen, doodelijk gewond. Beter door zijne landgenooten gesteund, zou hij voor Coen een kwade tegenpartij zijn geweest. Dat erkende deze zelf, toen hij, de tijding van Jourdain's dood aan Bewindhebbers mededeelende, er bijvoegde "dewelke voor auteur van alle deze onheilen gehouden wordt". " De Engelschen bleven te Patani in erbarmelijken toestand achter; hunne schepen werden door Hendrik Jansz naar Batavia medegenomen. 2

In Augustus viel in Straat Sunda het Engelsche schip "the Star" in handen der Hollanders 3, maar zwaarder was het verlies dat de Engelschen leden voor Tiku aan de westkust van Sumatra. Hier had, zoo als wij boven zagen, Dale een schip (the Rose) achtergelaten om het eskader van Robert Bonner te waarschuwen, dat daar uit Surate verwacht werd. Maar Bonner, hoewel gewaarschuwd, was slecht op zijn hoede, of misschien misleid door tijding uit Engeland, door het schip "the Bear" aangebracht, dat de vrede tusschen beide compagnieën zoo goed als gesloten was. Terwijl hij met vier schepen voor Tiku lag, bezig met peper te laden, zag hij den 11 October in de verte zes schepen aankomen, en meenende dat het de vloot van Dale was, maakte hij geen aanstalten tot verdediging. Te laat bespeurde hij zijn misslag, toen hem door den commandeur van het Hollandsche eskader, Willem Jansz, op eens de volle laag werd gegeven. Hoe weinig dus voorbereid, deed Bonner wat hij kon om zich te verdedigen, maar toen hij zelf doodelijk gewond en het schip doornageld was, moest de bemanning 't wel opgeven. De drie andere schepen waagden zich niet aan den ongelijken strijd en gaven zich over. De bemanning werd aan 't strand gezet, maar Willem Jansz liet hun een der schepen over om te kunnen vertrekken. Hij had van Coen in last

1 Ook Van Speult noemt hem in een brief aan Coen (4 Mei 1620) "de causa movens van alle dese proceduyren." Coen zou zoo dankbaar geweest zijn over Jourdain's dood dat hij Hendrik Jansz 1400 gulden en een gouden keten vereerde (Purchas I b, p. 696 onderaan).

2 Calendar II, No. 846, 877, 878; Geo. Muschamp bij Purchas Ib, p. 678; Th. Hackwell, ald. p. 693; Coen bij De Jonge, bl. 193; Resolutien GG. en Raden 14 Nov. 1619.

s Calendar II, No. 742; Coen bij De Jonge, bl. 187. 5e Volgr. II. 
om ook de Engelsche vloot aan de Kust van Koromandel te gaan opzoeken, maar thans moest hij zijn volk ook over de veroverde Engelsche schepen verdeelen en vond het dus raadzaam zijn buit eerst te Batavia op te brengen. Coen betreurde dit, maar zonder reden, want tegen de vloot, die Martin Pring thans onder zijn bevelen had, zou het eskader van Willem Jansz toch niet zijn opgewassen. 1

Het was eerst op den 4 Februari 1620 dat die vloot voor Tiku verscheen, waar zij nog drie schepen aantrof die in November 1619 onder Charles Clevenger uit Engeland waren aangekomen. Hier vernam Pring de rampen die de overige schepen getroffen hadden, zoodat het getal der verlorenen, schrijft hij, dat van het overschot hunner drie vloten bijkans evenaarde. De Hollanders daarentegen hadden nog negen schepen ter versterking gekregen ${ }^{2}$ en konden nu meer dan 30 bodems tegen de Engelsche overstellen. Pring aarzelde dus of hij hen niet zou ontwijken, te meer daar drie zijner schepen herstelling behoefden. Ten laatste schijnt toch het besluit genomen te zijn om naar Bantam te gaan en met den Pangeran te onderhandelen, in de hoop dat de Hollanders, die zonder twijfel van de vredehandeling in Europa kennis droegen, geen gevecht zouden uitlokken. 3 Maar die hoop zou wel onvervuld zijn gebleven, indien niet reeds nader tijding te Batavia was aangekomen. Straat Sunda doorzeilende ontmoette Pring den 18 April het Engelsche schip the Bull, vergezeld van het Hollandsche jacht het Vliegend Hert, die hem het blijde nieuws brachten dat den 17 Juli 1619 tusschen de Engelsche en Nederlandsche O. I. Compagnieën een tractaat van vrede en vereeniging was gesloten.

1 W. Hoare bij Purchas, I b, p. 661-62; Calendar II, No. 755, 760, 761, 763, 767, 878; Coen bij De Jonge, IV, p. 194-95; Resolutien GG. en R. 18, 19 Sept. 1619.

2 Onder Frederik Houtman, den 3 Sept. 1619 te Batavia aangekomen.

3 Pring bij Purchas I b, p. 639-40; Vgl. Hatch aldaar p. 620, 621, 687, en Calendar II, No. 802. 


\section{DERDE HOOFDSTUK.}

Inhoud van het accoord tusschen de Engelsehe en Hollandsche Compagnie. De Banda-eilanden in 1619-20. Standvastigheid van Nathaniel Courthope. Betrekkingen der Engelschen en Hollanders met Makassar, Solor (1616-20), Bali (1618-10), Sukadana, Sambas, Landak, Bandjarmasin, Burnei (1611-20), Patani, Sangora, Siam (1616-20), Atjeh (1615-20; Veroveringen van Iskander Muda), Djambi, Indragiri, Palembang (1618-20).

Drie weken te voren had "the Bull" de tijding der vereeniging te Batavia aangebracht. Dat zij Coen als een donderslag trof, kan ieder beseffen. "Grooten dank zijn de Engelschen u schuldig", schreef hij met bitterheid aan Bewindhebbers. "Zij hadden zich zelven recht uit Indie geholpen en de Heeren hebben er hen weer midden in gezet." Maar toen de Heeren dit deden, wisten zij wel dat Dale met een aanzienlijke vloot naar Indië was gegaan om de vermeende rechten zijner landgenooten te handhaven, maar niet hoe slecht hij daarin geslaagd was.

In 1618 waren de onderhandelingen tusschen beide Compagniën । hervat. Het denkbeeld van vereeniging hunner kapitalen bleek een hersenschim, daar men al aanstonds elkanders opgaven mistrouwde. Toen werd langen tijd gestreden over het deel dat aan iedere natie zou toekomen in de voordeelen van den handel en de kosten der verdediging. Dat de Engelschen thans geneigd waren een evenredig aandeel in die zoogenaamde verdediging te nemen, m. a. w. in den oorlog tegen de Spanjaarden, was reeds veel gewonnen. Maar op één punt stuitten de onderhandelingen weder af. De Engelschen eischten het recht om even als de Hollanders in de Molukken forten te bouwen. Zij zagen te recht in dat zij daar zonder forten aan de genade hunner bondgenooten waren overgeleverd. Van de laatsten was het echter te veel gevergd de voordeelen eens door hen behaald prijs te geven en forten te laten bouwen die eenmaal tegen hen gebruikt konden worden. Ten laatste hakte Koning Jacobus, die er op gesteld scheen dat men tot een vergelijk kwam, de knoop door. Men moest de kwestie van de forten voorloopig laten rusten; over twee of drie jaar kon men daar beter over oordeelen. De Bewindhebbers der

1 Vgl. hiervóór bl. 208. 
Engelsche Compagnie protesteerden ten sterkste tegen 't geen zij (uit eerbied voor den Koning) een "uitvindsel van de Hollanders" noemden 1, maar te vergeefs. De Engelsche Regeering stelde de goede verstandhouding tusschen beide natiën boven de belangen der Compagnie en troostte hen met het voorloopige van het accoord. Het zou echter spoedig blijken dat Bewindhebbers recht hadden en het tractaat veelmeer een bron van verbittering zou worden dan de weg tot beter verstandhouding. 2

Er werd dan in de hoofdzaak het volgende vastgesteld. De kapitalen der beide Compagnieën bleven gescheiden. De prijzen van verkoop der waren in Europa zouden onderling worden vastgesteld; wat den aankoop in Indië betreft, zou men "trachten met gemeen advies alle waren op een redelijken prijs te brengen." De peper die men op Java opkocht zou gelijk verdeeld worden. In de Molukken, Ambon en Banda zouden de Engelschen een derde aandeel in den handel verkrijgen. Voor het overige zou de handel vrij zijn. De forten bleven in handen van hen die ze tijdens het sluiten van het tractaat bezet hielden. Geen van beide Compagnieën zou de andere van den handel op eenige plaats in Indië kunnen uitsluiten. Zonder beider goedvinden zouden geen anderen deel mogen hebben aan de voordeelen van dit tractaat, ook geen onderdanen van den Koning van Engeland of van de Staten. Voor de verdediging ("defensie") zou een een vloot van 20 schepen onderhouden worden, elk van 6 à 800 ton en met 150 koppen bemand, waarin elke Compagnie voor de helft zou bijdragen. Een "Raad van defensie", uit 8 personen, vier van elke natie, bestaande, zou daarover het toezicht houden, voorts de rechten bepalen, te heffen op den uitvoer der waren, ten bate van het onderhoud der forten en garnizoenen, en maatregelen nemen om gezamenlijk den handel op China en andere gewesten in Indië te openen 3.

Men ziet, nu de Engelschen deel aan het monopolie konden krijgen, lieten zij hun strijd voor de vrije vaart in Indië en hunne bezwaren tegen vijandelijke bejegening der Spanjaarden wel varen. Want hoewel men blijkbaar vermeden had andere natieën in het tractaat te noemen en er alleen van "defensie" sprake was, aarzelden zij geen oogenblik hierin dezelfde lijn te volgen als de Hollanders.

\footnotetext{
1 Calendar, II, No. 683 II.

2 Zie over de onderhandelingen: De Jonge, IV, Inl. bl. CXIX-CXXVI en Calendar II, passim.

s Th. Rymer, Foedera. Ed. III. Tomi VII pars III, p. 115-17.
} 
Hoe het te Bantam en te Djakatra geschapen stond, toen het tractaat in Indië ontvangen werd, hebben wij gezien. Wij willen thans onderzoeken in hoever de Engelschen in andere deelen van den Archipel aandeel aan den handel verkregen hadden.

Dat zij in de Molukken en Ambonsche eilanden door het nauwe toezicht der Hollanders geen post hadden kunnen vatten, is ons bekend, en eveneens dat zij zich in de Banda-groep op Pulu-Run hadden gevestigd. Dank zij de geestkracht en volharding van Nathaniel Courthope hadden zij hier stand gehouden. Dale zond hem een jacht met provisie en schoone beloften, en het bericht van de vlucht der Hollanders had ook op de Bandaneezen zooveel invloed dat zij geen noten meer naar Nera brachten. Maar toen de Engelsche vloot wegbleef, en nu en dan schepen van de Hollandsche, die voor Ambon lag, zich te Nera vertoonden, kwamen de Selammers weder aan het fort handel drijven. Bij gebrek aan klein vaartuig konden echter de Hollanders niet beletten dat telkens Portugeesche en Javaansche jonken Pulu Run en de zuidzijde van Groot-Banda aandeden, om specerijen te koopen en provisie te brengen. Want met hun prauwen konden ze niets uitrichten, daar deze door de Bandaneezen, die 16 of 17 korakora's in zee hadden, genomen werden. Dikwijls leden zij dus evenzeer zoo niet meer gebrek dan de Engelschen, die nu en dan uit Makassar werden voorzien, en het was dus niet te verwonderen dat de Engelsche gevangenen op Nera er slecht aan toe waren en bitter klaagden. Willem van Antzen, in Februari 1619 hier gekomen om Hendrik Waterfort, die overleden was, als gouverneur op te volgen, had dus geen gemakkelijke tak, want zoo lang de Bandaneezen niet door nood of vrees gedwongen werden de Hollanders te vriend te houden, lieten zij hen in den steek. Dat zij de Engelschen evenmin vertrouwden, bleek wel hieruit dat zij op Pulu Run drie batterijen opwierpen, die de Engelsche sterkte op het eilandje Nailaka bestreken.

De komst van verscheidene vreemde jonken in 't begin van 1620 was waarschijnlijk de reden dat de Selammers weder geheel met de Hollanders braken. Aanleiding daartoe schijnt de moord van een Hollander geweest te zijn, waarover Van Antzen op de Selammers weerwraak nam ', hoewel zij beweerden dat de Lontoreezen de schuldigen waren. Toen Frederik Houtman, die door Coen tot commandeur

1 Dit blijkt niet uit de brieven van Van Antzen maar uit latere verklaringen der Bandaneezen. Zie "Conqueste van het eiland Banda" in deze Bijdragen II (1854) bl. 416. 
der scheepsmacht in de Molukken was angesteld, in April van dit jaar Banda bezocht, trachtte hij het geschil weder bij te leggen, maar de Bandaneezen verlangden dat hij met zijn Raad bij hen zou komen bitsjaren en daarin schijnt hij, met het voorbeeld van Verhoeff voor oogen, weinig zin gehad te hebben.

Courthope, die te Lontor een factorij had gevestigd, trachtte intusschen te bewerken dat de Lontoreezen den Koning van Engeland als hun opperheer erkenden, en was daarover met hen in onderhandeling toen hij, den 5 November van Lontor naar Pulu Run overstekende, door de Hollanders verrast werd. Courthope en de Bandaneezen die bij hem waren wilden zich niet overgeven Maar de vijand was hem te machtig. Toen reeds eenigen om hem gevallen waren en hij zelf in de borst gewond, sprong hij over boord om zich al zwemmende te redden, maar door bloedverlies verzwakt gelukte hem dit niet en schijnt hij door de Hollanders opgevischt en aan zijn wonden gestorven te zijn. De Engelschen verloren in hem een van hun beste mannen. Ook hun vijanden erkenden dit. "Kapitein Nathaniel", schreef Van Antzen aan Robert Hayes, den factor op Pulu Run, "is gedood in de prauw, en God weet dat ik er hartelijk bedroefd over ben. Wij hebben hem zoo eerlijk en statig begraven als zulk een man verdiende "

Hayes, die door de 23 Engelschen die zich nog op Nailaka bevonden tot Courthope's opvolger gekozen werd, zette de onderhandelingen met Lontor voort en bracht het zoover dat zij den 4 . December 1620 tegen afstand van eenig geschut hun land aan den Koning van Engeland overgaven, en zich verbonden aan niemand anders noten en foelie te verkoopen ${ }^{1}$. Twee dagen later kwam een Hollandsch jacht van Ambon de tijding brengen dat de vrede tusschen de Compagniën gesloten was. De Bandaneezen maakten zich met hun korakora's van dat jacht meester en brachten het te Run op, waar Hayes de brieven opende en het nieuws vernam. "Wij verblijdden ons in het accoord", schrijft Hayes "maar wisten niet hoe ons tegenover de inlanders te rechtvaardigen." Hoe hij zich in die moeielijkheid gedroeg zullen wịi later zien. Van Antzen, wien hij de brieven overzond, gaf hem te kennen dat hij nu "kon gaan

1 Het contract vindt men bij Purchas I b, p. 703. Het is geteekend door de Sjahbrndara's van Lontor en Ratu, in tegenwoordigheid der Orangkaja's van Lontor, Labetaka, Pulu Ai en Pulu Run. De inwoners van Labetaka, Nera en Ratu, vroegere kampongs op het eiland Nera, hadden toen de Hollanders hun eiland in bezit namen, op de andere eilanden de wijk genomen. 
waarheen hij wilde." Maar dit zullen de Bandaneezen wel niet met Van Antzen eens zijn geweest 1 .

Te Makassar waren thans de Engelschen de eenige Europeërs die eene factorij bezaten. De Portugeezen uit Malaka kwamen er echter de specerijen koopen die de Spanjaarden er uit de Molukken brachten en die de Makassaren zelven hadden weten machtig te worden, en als zij er die niet vonden, voorzagen ze zich van rijst. De Hollanders waren er wel op uit om de Makassaren het opkoopen van specerijen te beletten, en het was alleen omdat hij het hun anders zou moeten toestaan dat Coen geen vrede met hen sloot ${ }^{2}$. Maar zij legden zich meer en meer op de zeevaart toe en om hen overal te betrappen hadden de Hollanders zelven veel meer klein vaartuig moeten bezitten 3 .

Ook op de eilanden beoosten Java kwamen de Hollanders met de Makassaren in botsing. De Soloreezen waren, nadat Reynst de bezetting van het fort had teruggeroepen, weder aan de Makassaren en Portugeezen overgeleverd. De laatsten hadden zich, zooals wij weten, te Larantuka op Flores gevestigd 4 en zoowel van Malaka als van Macao werden fregatten uitgezonden om door hun bemiddeling het sandelhout op te koopen. De paters Dominikanen drongen er bij den Vicekoning te Goa, Geronimo de Azevedo, op aan om het fort op Solor weder van bezetting en geschut te voorzien, en gaven hoog op van de bekeerlingen die zij daar en op de omliggende eilanden gemaakt hadden, maar Azevedo begreep wel dat zij dit overdreven - zij spraken van 100,000 zielen! - en had geen bekeeringsijver genoeg om zoo ver af oorlog te zoeken met de Hollanders en hen als het ware uit te lokken om het fort weder te veroveren 5.

Kaitjil Partani en de sengadji's der bevriende dorpen op Solor zonden hun zonen naar Djakatra om bij Coen op bijstand aan te dringen, en daar hij inzag dat hij het sandelhout niet kon missen

1 Zie over 't voorgaande Courthope's Journaal, vervolg d door Hayes, bij Purchas I b, p. 671-681; Pring bij Purchas, p. 636; Calendar II, p. 253 en Preface p. XLIV-XLVIII; Coen aan Bewindh., 29 Sept. 1618, 5 Augustus 1619 (bij Dodt p. 204), 15 Oct. 1619 , 31 Juli 1620 ; H. van Speult aan Coen, uit Ambon 31 Aug. 1619; W. van Antzen aan Coen 16 Mei, 13 Juni 1620; Fred. Houtman aan Coen, 19 Mei 1619.

$2 \mathrm{Vgl}$. hiervóór bl. 202.

3 Th. Staverton in Calendar, II, No. 746; Memorie van Jan Joosten (1621) later te vermelden.

4 Achtste gedeelte, bl. 340.

5 Bocarro, Decada XIII da historia da India (iisboa 1876) II, 723-24. 
dat door de Chineezen zeer gezocht werd, zond hij in December 1617 weder twee jachten naar Solor, die de vaartuigen der Portugeezen in brand staken en eenige Hollanders op Solor achterlieten met de belofte dat men er weer "een bolwerk met wat volk" zou leggen. In September 1618 werd daartoe Gillis Seys met twee jachten uitgezonden. Hij deed onderweg Bima op Sumbawa aan en liet ook daar een koopman met gevolg achter. De radja, die onder den druk der Makassaren gebukt ging, even als de Soloreezen, had door bemiddeling der laatsten laten vragen waarom de Hollanders, die hem eens bezocht hadden, niet teruggekomen waren, en daar Coen vernam dat te Bima veel rijst te bekomen was, gaf hij an die uitnoodiging gehoor. De uitkomst was echter noodlottig, want kort daarna werden de Hollanders door Agostinho Lobato, die met een Portugeesch fregat de plaats aandeed, overvallen en gedood of weggevoerd.

De Portugeezen zagen zeer noode dat de Hollanders onder Cryn van Raemburch het fort Henricus op Solor herstelden en de vaart op Timor hervatten. Te vergeefs trachtten zij het fort te verrassen. Te Ende echter verwoestten zij met hunne bondgenooten van Numba de kampongs die zich bij de Hollanders hadden aangesloten, en in Amanoebang op Timor vermoordden zij eenige Hollandsche kooplieden. Toen in Mei 1620 drie Hollandsche schepen Solor aandeden, haalde Raemburch de kapiteins over om de Portugeezen te Larantuka aan te tasten. Drie compagniën, van $62 \mathrm{man}$, door eenige Soloreezen gevolgd, landden in de nabijheid der plaats, maar te weinig met het terrein bekend, lieten zij zich in eene engte lokken en werden daar door de Portugeezen overvallen. Hierdoor ontstond een paniek en namen de Hollanders overhaast de vlucht, door den vijand gevolgd. Voordat zij de schepen bereikten, waren velen gedood en gekwetst.

De handel op Timor bleef nog grootendeels in handen der Portugeezen, die daarmede van ouds bekend waren en met hun kleine vaartuigen de kust aandeden op plaatsen waar de Hollandsche schepen niet konden ankeren. Deze vischten dus dikwijls achter 't net. 1

In 1618 werd door de jachten die zich naar Solor begaven ook Bali aangedaan. De vorst van dat eiland heette de Hollanders welkom

1 Zie over 't voorgaande: Coen aan Bewindh., 22 Aug. 1617, 24 Juni, 26 Juli 1618, 5 Aug. 1619, 31 Juli 1620; Resol. GG. en Raden 1617-19; C. Buysero aan Bewindh., uit Bantam 31 Aug. 1617; A. Gijsels in Kronijk Hist. Gen. 1871, bl. 527, 528; Journaal van W. IJz. Bontekoe (Hoorn 1648) bl. 25; Faria y Sousa, Asia Portuguesa, III, p. 338-39. 
en stond hun toe mondkost te koopen. Hij wilde hen gaarne te vriend houden, omdat de Makassaren het eiland Lombok bedreigden, dat tot zijn gebied behoorde. Op zijn dringend verzoek zond Coen in Januari 1620 den koopman Jan van Meldert naar Bali om er een kantoor te vestigen. Het schijnt echter dat de vorst toen tegen de Hollanders was gewaarschuwd; althans hij schonk hun niet het vertrouwen waarop zij gerekend hadden. Misschien ook waren de baten te gering, hoewel de vorst verlof gegeven had tot het opkoopen van slavinnen; althans in Januari 1621 zond Coen weder een fregat naar Bali om het volk te lichten. 1

Te Sukadana, zetel van den diamanthandel aan Borneo's westkust, waren in 1611 de Engelschen 2 op het voetspoor der Hollanders handel komen drijven. In 1613 vestigden zij er een factorij. Te Sambas aan dezelfde kust hadden de Hollanders, zoo als wij vroeger gezien hebben, met den radja een contract gesloten om daar alleen de diamanten te mogen opkoopen. In December 1610 , terwijl zij met een jacht voor de stad lagen, liet hij hen verraderlijk vermoorden, waarschijnlijk om het jacht met geschut meester te worden. De Indische regeering begreep dat zij dien gruwel niet ongestraft kon laten en zond in Maart 1612 vier jachten uit, om zoowel Bandjarmasin, waar vroeger een dergelijke moord h́ad plaats gehad, als Sambas te straffen. Een verhaal van dien tocht is ons niet bewaard gebleven. Alleen weten wij dat Bandjarmasin in brand geschoten en verwoest werd. Of Sambas hetzelfde lot onderging, wordt ons niet gemeld. De moord der Hollanders schrikte de Engelschen niet af om te Sambas eveneens hun geluk te beproeven. In 1614 zonden zij er den koopman Cassarian David heen, maar deze bemerkte spoedig dat hij er evenmin veilig was en voor het jaar ten einde was, kwam hij met zijn goederen en slaven te Sukadana terug. Beter gevolg had een tocht die dezelfde David in 1615 naar Bandjarmasin ondernam. Hij werd er zeer welwillend ontvangen en vond er (schrijft hij) even goede diamanten als de Landaksche en bizonder goede en groote bezoar-steenen en goud-

1 Coen bij De Jonge, IV, p. 191, 207; H. van Speult aan Coen, uit Ambon 24 Juli 1619, 4 Mei, 14 Aug. 1620; Resol. GG. en R. 22 ¿Dec. 1619, 14 Jan. 1620; Coen aan J. van Meldert, 25 Jan. 1621; A. Gijsels in Kronijk Hist. Gen., 1871 , bl. 529.

2 Namelijk Augustine Spalding op last van David Miłdleton. Zie Calendar I, p. 347 en vgl. ons Zevende Gedeelte, bl. 76, aant. 3. - In November 1612 heet het nog dat zij er eene factorij zullen vestigen (Calendar I, No. 710). Zij hadden daar toen een "legger", d. i. een jacht dat in de rivier bleef liggen. 
zand. ' Sedert bleven de Engelschen hier ongestoord handel drijven. 2

Ook met Landak zelf, waar de diamanten gevonden werden, trachtten zij in betrekking te komen (want te Sukadana was de Koningin, tot wier gebied Landak behoorde, tusschenpersoon bij den diamanthandel). De radja van Sambas beloofde hun, evenals indertijd aan de Hollanders, uit naijver op Sukadana, zijn steun, maar was ook nu niet in staat die belofte na te komen, want de Engelschen werden tweemaal door de Dajaks zoo vijandig ontvangen dat zij hun pogingen moesten opgeven.

Te Sukadana joegen nu de Engelschen en Hollanders den prijs der diamanten tegen elkander op, zoodat de voordeelen gering werden en de laatsten er aan dachten hun factorij op te heffen. Een groot bezwaar bij dien handel was ook de verleiding voor de kooplieden om voor eigen rekening aankoopen te doen, en weinigen, zoowel Hollanders als Engelschen, waren daartegen bestand. Coen oordeelde echter dat men zich niet moest laten ontmoedigen, en werkelijk werden sinds 1616 de baten weer veel aanzienlijker, daar de Engelschen bij gemis aan kapitaal zich van aankoopen moesten onthouden en hunne kooplieden zelfs gebrek leden. ${ }^{3}$

Hoe het kwam dat Burnei, de zetel van den eenmaal machtigen Sultan van Borneo's oostkust, waarnaar het eiland door de Europeërs genoemd werd, noch door Hollanders noch door Engelschen meer bezocht werd, wordt ons opgehelderd in een brief van den factor Hendrik Jansz te Patani van 20 October 1614. De Koning van Borneo, schrijft hij aan Bewindhebbers, heeft een gezant aan de Koningin alhier gezonden om de vriendschap te onderhouden en hem een brief aan ons medegegeven, waarin hij ons uitnoodigt volk bij hem te zenden en een kantoor te stichten. Wij hebben hem daarop geantwoord dat wij geen volk hadden en geen order om aan zijn verlangen te vol-

1 "The people of Banjermassin are very sociable and kind, their language is Malay and their habit Java." Cass. David in Calendar I, No. 1076.

${ }^{2}$ Zie Calendar II, No. 73, 234, 359, 909.

3 "Sy en hebben.... haer hoeren moeten vercuopen om de cost te crygen ende haer huys op te houden." Coen aan Bewindh. 5 Aug. 1619 (bij Dodt bl. 202). Deze "hoeren" waren een handelsartikel. Zie A. Gijsels in Kronijk Hist. Gen. 1871, bl. 530. - Over het voorgevallene te Sukadana, Landak en Sambas zie men Calendar I, No. 710, 732, 736, 748, 760; 1076 ; vgl. p. 302 ; Calendar, II, No. 234, 353, 373, 597, 643, 648; Van Dijk, Neerl. vroegste betrekk. met Borneo etc., bl. 3-7, 142-164; Coen in Bouwstoffen door mij uitgeg. bl. 61, 62; voorts brieven van Coen aan Jos. de Natelaer van 19 Mrt. en 9 Juli 1620, die Van Dijk niet heeft geraadpleegd. 
doen, maar dat wij zijn brief aan den Gouverneur-Generaal zouden opzenden. Belangende den handel, gaat Jansz voort, deze bestaat meest in kamfer, was, bezoarsteen en schildpadhoorn, maar is niet van genoeg beteekenis om de kosten van een kantoor te bestrijjden. De Portugeezen hebben er voor dezen goede profijten gedaan, maar thans komen zij er ook niet meer. De Engelschen, voegt hij er bij, "hebben plan er met een partij doeken heen te gaan." Wij vernemen dit ook uit hun brieven ' , maar het schijnt bij het plan te zijn gebleven.

Even als te Sukadana ging het te Patani, de kleine Maleische kuststaat, waar men de zijde van de Chineezen opkocht. In 1614 is Coen zeer tevreden over het ontvangen cargasoen, terwijl de Engelschen klagen dat bij gebrek aan Chineesche waren hun geld en goederen ongebruikt blijven liggen. Een jaar later klaagt de Hollandsche factor weder over de groote concurrentie van de Engelschen. De Chineezen, die hier hooge rechten moesten betalen, bewogen de Hollanders zich te Sangora te vestigen, een plaats die iets hooger aan de kust ligt en toen aan den radja van Bondelong behoorde, een zoon van den vorst van Ligor, welke laatste als vazal van Siam te Ajudhja verblijf hield en daar in 1612 met de Hollanders een contract sloot, waarop Cornelis van Nijenrode zich te Sangora vestigde en er eene faktorij liet bouwen. De Engelschen verzochten den radja in hetzelfde voorrecht te mogen deelen, maar dit werd hun geweigerd. Een tijdlang werd nu Sangora door de Chineezen bezocht en bracht de Hollanders zooveel voordeel dat de Engelschen er van gewaagden als van "een tweede Djakatra." Maar het duurde niet lang of de Chineezen werden ook hier en te Ligor door de Maleische vorstjes zoodanig afgezet dat de handel hun te weinig baten gaf in verhouding tot de verre en moeielijke reis. In 1616 schreef Coen aan den factor Hendrik Jansz of 't niet beter zou zijn de kantoren te Patani en te Sangora te lichten, daar de Chineezen toch liever hun waren naar Bantam brachten. Hendrik Jansz ontried dit, omdat de Hollanders hier zeer gewild waren en de handel wel kon verbeteren. Patani was nog niet afhankelijk van Siam en de Koningin 2 had meer macht en beter inkomsten dan de vorstjes van Ligor en Bondelong, die zelven nauwelijks Hof konden houden.

Ook in Siam, waar de Hollanders en Engelschen, zoo als wij weten, in de hoofdstad Ajudhja hun kantoren hadden, was de handel zeer

\footnotetext{
1 Calendar, I, No. 760, 862.

${ }^{2}$ De oude Koningin, die 32 jaar (in naam) 't bewind gevoerd had, was in 1616 overleden en door haar zuster opgevolgd.
} 
achteruitgegaan ten gevolge der inlandsche oorlogen, maar voor de vaart op Japan was de plaats niet zonder gewicht. De vorst van Siam hield de vreemdelingen gaarne te vriend, opdat zij de scheepvaart zijner onderdanen niet zouden belemmeren.

In 1617 traden aan deze kusten de Portugeezen weder als mededingers op. De vice-koning te Goa zond in Maart 1616 den Dominikaan frei Francisco da Annunciaçāo, die in Achter-Indië gereisd had, als gezant naar Ajudhja om met den Koning van Siam een verbond te sluiten en hem te verzoeken de "hollandsche roovers en rebellen" niet in zijn land te gedoogen, omdat zij den handel tusschen Siam en Malaka beletten. De gezant kreeg hierop ten antwoord dat de Portugeezen ' $t$ aan zich zelven te wijten hadden, als er geen jonken uit Siam meer te Malaka kwamen, omdat ze hen aan den mond der zeestraat meermalen beroofd hadden. De Hollanders, Engelschen en Maleiers daarentegen bejegenden zijn jonken altijd met eerbied, en hij wilde hen niet tot vijanden maken. Hij was echter zeer genegen ook aan de Portugeezen den handel in zijne havens en die zijner vazallen toe te staan en zou de Koningin van Patani kennis geven, dat zij zijn voorbeeld had te volgen, indien van Portugeeschen kant geen bezwaar werd gemaakt de invoerrechten te betalen. Twee Siameesche gezanten vergezelden in November 1616 den Dominikaan naar Goa en van daar naar Portugal om het verbond te bevestigen 1 .

Sedert stonden zoowel Patani als de havens der Siameesche vazalstaten voor de Portugeezen open, en zij maakten weldra een druk gebruik van die vergunning en werden zeer ontzien en in eere gehouden. En was reden voor, daar zij, zoo als een Hollandsch koopman vermeldt, de Maleiers zoo goedkoop van kleeden voorzagen, "dat wij er niet tegen op kunnen." In 1619 waren zij te Patani met hun slaven al over de honderd man sterk, en toen de Engelschen eens twist met hen zochten kwamen deze er slecht af. De handel was voor hen en de Hollanders nu van geringe beteekenis geworden en op last van Coen deden sinds 1620 de laatsten hun best de jonken die er kwamen, zoowel van Chineezen als van Siammers, over te halen naar Batavia te varen, waar het heette dat zij vrij van alle lasten zouden zijn 2.

${ }^{1}$ Bocarro, a. w. II, 516-530; Faria y Sousa, III, 281, 282. De Hollanders, zegt B., hadden te Ajudhja [er staat Ova voor Odia] een factorij met groot kapitaal, de Engelschen met kleiner.

${ }^{2}$ Zie over 't voorgaande: brieven van Abr. van den Broeck aan Pt. Both., uit 
Te Atjeh hadden in $1615^{1}$ de Engelschen het monopolie voor twee jaren weten te verkrijgen en de Hollanders hun loge gelicht. De bevoorrechten hadden van den trotschen Sultan Iskander Muda en zijne inhalige beambten te Tiku heel wat te verduren. De Maleiers, die de peper uit het binnenland aanbrachten, moesten reeds een vierde van de waarde aan den Sultan afstaan en mochten die dan nog niet aan de vreemdelingen verkoopen, voordat de goederen door de Atjehers aangebracht voor een vasten prijs waren opgeruimd 2 . Bovendien moesten de Engelschen voor zij iets mochten koopen aan een aantal lieden den mond stoppen. En daarbij kwam dan nog dat de handelaars uit Guzerate, die hier veel ouder brieven hadden dan de Engelschen, hen tegenwerkten en met goed gevolg, daar zij beter wisten welke kleeden hier getrokken waren dan hun mededingers $\mathbf{3}$.

Waren de voordeelen hier al gering, ze werden hun door den Sultan nauwelijks gegund. Hij deed telkens nieuwe eischen, en toen er kwestie van was het contract te verlengen, weigerde hij dit ten stelligste. Zijne Orangkaja's en kooplieden leden nadeel bij het contract en werkten het tegen, en hij zelf wilde den handel zooveel mogelijk van de Maleische kust naar Atjeh verplaatsen 4. Tot de weigering kan ook hebben bijgedragen dat het de Engelschen aan middelen ontbrak om groote aankoopen te doen en dat zij te weinig aanvoer van kleeden uit Surate kregen $\mathbf{5}$.

Dat de Hollanders in den Archipel machtiger waren dan hunne

Patani 17 Juni 1612; Corn. van Nijenrode en Mt. Houtman uit Judea (Ajudhja) aan Hend. Patani, 1612-13; Coen aan Bewindh. 1 Jan. 1614 in Bouwstoffen, p. 62, 63 ; Hend. Jansz aan Bewindh., uit Patani 20 Oct. 1614, 25 Oct. 1616; Coen aan dez. 27 Dee. 1614; Brieven tusschen Hend. Jansz en Coen 1615-17; Corn. van Nijenrode uit Judea aan Bewindh. 20 Sept. 1617; G. Fz. Druyff aan dez. 4 Oct. 1618, 26 Mrt. 1619, en aan Coen 8 Mrt. 1620; Coen aan Druyff 3 Mei 1620; Calendar I, No. 748, 749, 1091, 1118, 1148, 1170; II, No. 89, 140, 221. Zie ook Van Dijk, Zes jaren uit het leven van W. van Berchem, p. 32 aant. 3. (Van de stad Bankok ["Bancope"] wordt reeds gesproken door Adam Denton in 1614. Zie Calendar I, p. 324). - Sinds 1614 handelden Hollanders en Engelschen ook in Cochinchina en de laatsten in Cambodja. Wat ik daarvan gevonden heb deel ik elders mede.

1 Achtste gedeelte bl. 305 .

${ }^{2}$ Er was dan ook weinig noodig om in die kustplaatsen de Maleiers tegen de Atjehers in opstand te brengen. Zie J. Millward hieronder.

s John Millward bij Purchas I b, p. 527 en in Calendar I, No. 1111; W. Peyton bij Purchas p. 432. Voorts Calendar II, No. 388, 590, 879.

4 Calendar II, No. 134, 245, 360, 365, 384, 515.

5 Calendar II, No. 119, 134, 246, 365. 
mededingers, bleef natuurlijk den Sultan niet onbekend, en toen Coen vernam dat hij hun vriendschap op prijs bleef stellen, zond hij in 't laatst van 1616 Cornelis Comans naar Atjeh om hem die aan te bieden, indien hij hun "de profijten die de Engelschen nu hebben" wilde laten genieten. Iskander was in dien tijd zeer ziek 1 en kon dus Comans niet te woord staan, maar liet toch gelasten dat de Engelschen, die de Hollandsche factorij betrokken hadden, deze voor hen moesten ruimen 2. Een jaar later kwam Comans terug met hetzelfde verzoek. De Sultan hield zich eerst vertoornd, maar door een "groote schenkagie" kregen de Hollanders hun zin en werd hun de handel te Tiku voor twee jaar gegund, daar het contract met de Engelschen spoedig ten einde liep. De koopman Nicolaas de Casembroot bleef nu met gevolg te Atjeh achter. In 't eerst hield de Sultan de Engelschen van 't contract onkundig, maar toen Coen in Juli 1618 een Atjehschen gezant, die den vorst van Mataram bezocht had, naar zijn land liet terugbrengen, gaf hij tevens in last bij den Sultan op uitsluiting der Engelschen van den handel te Tiku en Priaman aan te dringen, wat deze ook eindelijk toestond op voorwaarde dat de Compagnie hem zijn oude schulden zou kwijtschelden ${ }^{3}$.

Comans, die zeer wel merkte dat de Maleiers in de peperhavens volstrekt niet op de Hollanders gesteld waren, had de onvoorzichtigheid zich met hun geschillen in te laten. Te Priaman liet een aanzienlijk Maleier ${ }^{4}$ hem bij zich komen en deelde hem mede dat hij en Maharadja Lela - welke Maleische vorst onder dien titel wordt angeduid is mij niet bekend - wel 4 à 500,000 weerbare mannen bijeen konden brengen om de Hollanders te steunen als zij de Atjehers uit Priaman verdreven. Comans stond hem toe met een Hollandsch schip gezanten naar Djakatra te zenden om daarover met Coen te spreken. Deze keurde die ongeroepen inmenging natuur-

${ }^{1}$ In Aug. 1617 schrijven de Eng. kooplieden: De Koning is 10 maanden ziek geweest en dikwijls zinneloos; de Koning is bijkans een krankzinnige, "wilful and wild." Calendar II, No. 134, 136.

2 Coen aan Bewindh., 22 Ang. 1617; Vgl. Resol. Djakatra 26 Sept. 1616, 23 Juni 1617, Calendar II, No. 51 .

${ }^{3}$ Corn. Comans aan Bewindh. 12 Mrt. 1618; Coen aan dez. 11 Mrt., 12 Nov. 1618, 14 Jan. 1619; Coen aan Comans en Casembroot 7 Juli 1518, Mt. Pring bij Purchas, p. 634; Calendar II, No. 257, 281, 285, 365, 384.

${ }^{4}$ Hij wordt door Comans "Radja Settia Phalawan" genoemd. - Maharadja Lela zou vroeger aan 't Hof te Atjeh gewoond hebben en gevlucht zijn omdat de Sultan gijn vrouw wilde misbruiken. Was het dezelfde als Radja Lela Wangsa over wien men vgl. Bouwstoffen, door mij uitgeg. bl. 77? 
lijk af en Iskander, wien de plannen van den Maharadja niet verborgen bleven, liet in 1621 te Tiku een fort bouwen. Comans gaf ook als koopman blijk van ongeschiktheid, daar zijne zuinige aanbiedingen oorzaak waren, dat de peper van Tiku naar Atjeh vervoerd en aan de Engelschen verkocht werd, die er gaarne meer voor gaven, al was het alleen om te toonen, dat het voordeeliger was met hen te handelen 1. Zij kwamen in dezen tijd ook weder meer in de gunst bij den Sultan. Kapitein Bonner bracht hem in April 1619 een welkom geschenk uit Engeland, namelijk "twintig doggen (reuën en teven)", maar het groote kanon dat hij had gevraagd, "waarin een man rechtop kon zitten.", schenen de Engelschen hem niet te kunnen verschaffen; het stuk geschut dat zij hem vereerden achtte hij het ankijken niet waard 2. Bonner wist nu te verkrijgen dat hem de handel te Tiku voor twee maanden werd gegund.

De tijding van den vrede tusschen de Engelschen en Hollanders was Iskander natuurlijk niet aangenaam, want zij zouden nu niet meer door groote geschenken elkander zoeken te verdringen. Hij toonde echter dat hij niet voor hen bevreesd was, want toen zij er nu gezamenlijk op aandrongen hun den handel in de peperhavens toe te staan, maakte hij hen uit voor onbeschaamde bedelaars en zwoer hij dat, als zij oorlog zochten, hij gereed was om met hen den strijd aan te gaan en Allah om hem de overwinning te geven. Wilden zij peper hebben, dan zouden zij die voortaan uit zijne hand moeten komen eten, want alle andere peperplaatsen die nog niet tot zijn gebied behoorden: Djambi, Indragiri, Patani en anderen zou hij wel weten te noodzaken om hem hun peper te brengen en aan niemand anders 3. Coen was echter niet de man om zich door zulke groote woorden vrees te laten aanjagen. "Den Atchijnder", schreef hij aan Bewindhebbers, "mach wat wupsteerten, stoffen en blaesen; te sijnder tyt moet hij der al mede aen." ${ }^{4}$

De macht van den "Atchijnder" was evenwel niet zoo geheel te versmaden. Op de westkust van Sumatra strekte zij zich in 1620 uit tot voorbij Kota Tengah. Indrapura was nog onafhankelijk en zond zijn peper deels naar de noordelijke havens, deels naar Bantam.

1 Comans aan Coen, uit Priaman 25 Jan., 28 Jan. 1619; Coen aan Bewindh., 5 Aug. 1619, 8 Jan. 1621; Calendar II, 590, 663.

${ }^{2}$ Calendar, II, No. 760. Vgl. I, No. 1131.

3 J. Coetely aan Coen, uit Atjeh 1 Juli 1620; Pt. de Carpentier aan Bewindh. 8 Mrt. 1621; Calendar II, No. 933.

4 Coen aan Bewindh. 26 Oct. 1620. 
Van Selebar af behoorde de kust tot het gebied van Bantam '. Aan de oostkust was men overal in vrees voor Iskander's aanslagen, en zochten de Maleische vorstjes hun heil in een nauw verbond, ondersqua besling en met Djohor ${ }^{2}$. De Sultan van Djohor/2 Hammat Sjah, had if weden zich thans op Iingga zooveel mogelijk versterkt. Van Malaka had now the hij geen hulp te verwachten, want de Portugeezen moesten zelven vevoer. al hun krachten inspannen om hun stad voldoende te versterken, en over leow boden aan Hammat groote sommen, als hij hun zijn geschut wilde Alaooddinverkoopen 3. Hij werd zelf echter voortdurend door Atjeh bedreigd. Netuchen In 't begin van 1618 zond Iskander een vloot waarop zich 17000 K. B.S. 35 man zouden bevonden hebben naar Pahang, waar, zoo als wij weten, 15.3r. een zoon van Hammats broeder (den vorigen Sultan van Djohor) het bewind voerde. De stad werd verwoest en de vorst met duizenden zijner onderdanen naar Atjeh medegevoerd. "Ik zag", verhaalt Pieter van den Broecke, "den Coninck van Pahan als een slecht persoon achter den Coninck van Achien loopen." ${ }^{4}$ Hammat Sjah had hierop aan Coen dringend om hulp verzocht, maar het bleef bij kleine geschenken en betuigingen van vriendschap $\mathbf{5}$, een schrale troost voor den Djohoriet! Voor het hem gold, moesten echter nog anderen den sterken arm van Atjeh gevoelen. Nog in 't zelfde jaar 1618 kwam de Atjehsche vloot voor Malaka, veroverde een galjoen met 40 stukken geschut en nam de bemanning, waarbij zich de zoon van den gouverneur van Malaka bevond, gevangen. 6 Vervolgens begaf zij zich naar Kedah, ten noorden van Malaka, en in weerwil dat Patani de verdedigers hulp zond, werd ook deze stad in 1619 bemachtigd, de peperranken in den omtrek uitgeroeid en de oude Sultan met 4000 man naar Atjeh weggesleept. 7 Het volgende jaar

\footnotetext{
1 W. Peyton bij Purchas, p. 532; Corn. Comans aan Bewindh. 25 Jan 1619, 24 Jan. 1620.

2 Zie Achtste gedeelte, bl. 353.

3 A. Soury uit Djambi aan Bewindh. 25 Sept. 1618; A. Jz. van der Dussen uit Djambi an Coen, 27 Dec. 1620; Faria y Sousa, Asia Portuguesa III, 328, waar men voor Joroon natuurlijk Jor moet lezen.

${ }^{4}$ Corn. Comans aan Bewindh. 12 Mrt. 1618; Journaal van Pieter van den Broecke in "Begin en Voortg. der O. I. Comp." bl. 86. - Den 27 Febr. 1619 schrijft Comans aan Coen: "In Atchyn is Orangkaya Laxamana ven de Pahanders gequetst... Den Coninck heeft meer als 100 van de principale Pahanders doot doen smyten en in de riviere werpen."

${ }_{5}^{5}$ Coen aan Bewindh. 24 April 1618; Resol. D)akatra 13 Aug. 1618.

${ }^{6} \mathrm{Zij}$ werden later vrijgelaten. Calendar, II, No. 515.

7 Corn. Comans aan Bewindh., 24 Jan. 1620; Coen aan dez. 26 Mrt. 1622; Voyage d' A. de Beaulieu, by Thévenot, Relations, 2e partie, p. 83, 114.
} 
gold het Perak aan dezelfde kust. Ook deze plaats werd veroverd en 5000 man gevankelijk medegenomen. 1 De bedreigingen van Iskander Muda aan de Europeesche "bedelaars" waren dus wel iets meer dan ijdele grootspraak. ${ }^{2}$

De bloeiendste staat van Sumatra's oostkust was in dezen tijd Djambi. De handel was daar weder levendig geworden, toen in 1618 de geschillen in 't binnenland geslecht waren en de inlanders weder veel peper de rivier afvoerden. Hollanders, Engelschen, Portugeezen, Maleiers, Siammers betwistten elkander hier die gezochte koopwaar. De Hollanders hadden zich te groote vrijheden veroorloofd en waren vooral na de komst van Dale voor Bantam weinig gezien. Maar toen in 1619 de tijding aankwam van de verovering van Djakatra en het vertrek der Engelsche vloot, kwamen zij weder zeer in de gratie. De Engelschen waren nu geheel ontmoedigd en maakten zich gereed de plaats te verlaten, toen het bericht van de vereeniging der beide compagnieën hen van dit plan deed afzien. ${ }^{3}$

Te Indragiri en Palembang was de handel van veel minder beteekenis dan te Djambi, zoodat de Engelschen dien aan de Hollanders overlieten. De radja van Indragiri was in 1618 overleden en door zijn zoon opgevolgd. Hoe weinig deze vorstjes te vertrouwen waren, was vroeger aan de Engelschen gebleken en zouden ook nu de Hollanders

1 Pt. de Carpentier aan Bewindh., 8 Mrt. 1621.

2 Nieuwere schrijvers vermelden ook dat Iskander in 1619 Deli aan Sumatra's Oostkust en in 1621 Padang veroverde. Beide beweringen zijn blijkbaar ontleend aan 't verhaal van Augustin de Beaulieu (waarover later), die zich in 1621 te Atjeh bevond. Beaulieu geeft echter geen jaartallen. Wat Padang betreft, de inlijving bij Atjeh kumnen wij wel met Valentijn op 1620 of 1621 stellen. In December 1620 , toen Beaulieu voor Tiku lag, zag hij Atjehsche galeien, elk met 300 gewapenden en een olifant, voorbij varen om een Maleischen vorst, die tusschen Priaman en Indrapura woonde en tegen Atjeh was opgestaan, te beoorlogen (Voyage p. 41) en later spreekt hij van Padang als van een veroverd gewest. - Van de verovering van Deli makt zoo ver ik weet geen andere tijdgenoot melding dan Beaulieu. Deli was volgens zijn zegsman een sterke plaats, verdedigd door een man, beroemd om zijne dapperheid en door de Portugeezen hooggeacht; de gouverneur van Malaka had hem bezocht en getuigd dat Malaka gemakikelijker te bemachtigen zou zijn dan Deli, maar toch gelukte dit aan Iskander in korten tijd, door middel van loopgraven, en in weerwil dat de Portugeezen hulp boden. Bij dit beleg werden 100 olifanten gebruïkt. (Voyage, p. 100, 105), Veel waarschijnlijks heeft dit verhaal niet. Zou met Deli hetzelfde rijk bedoeld zijn dat de Portugeezen Aru noemen? Dan zal de verovering omstreeks 1612 hebben plaats gehad.

3 Briefwisseling tusschen Coen en A. Soury in 1618; Coen aan Bewindh., 5 Aug. 1619 bij Dodt, p. 218; A. Jz. van der Dussen uit Djambi aan Coen, 25 Juli 1619; Coen an Bewindh. 11 Mei 1620; Calendar II, No. 512, 662, 664, 835. 5e Volgr. II. 
ondervonden hebben, toen een hunner jachten in de rivier van Indragiri op een bank stootte en verlaten moest worden, want, indien niet bij tijds een ander jacht uit Djambi was komen opdagen, zouden zij ter wille van 't geschut en de goederen door de Maleiers zijn vermoord geworden. Als Coen goed was ingelicht, hadden zij daartoe te Malaka hulp verzocht en kwam deze te laat. I

Te Palembang, vroeger in oorlog met Bantam, ondervonden de Hollanders na Coens overwinning veel vriendschap van den Sultan. In 1619 werd hier voor 't eerst een assistent achtergelaten. Toen Coen er in 1620 een jacht heenzond om hout, rijst, arak enz. te laden, liet hij den Sultan (waarschịnlijk op zijn verzoek) vereeren: twee zilveren brillen, een Hollandsche kat en een "afconterfeytsel van Amsterdam met ontwerp van verscheydene schepen en galleyen." 2

1 Coen aan Bewindh. 22 .Jan. 1620.

2 Coen als v.; Dez. aan den Con. van Palembang, 11 Aug. 1620 


\section{VIERDE HOOFDSTUK.}

Verhouding tusschen de Engelschen en Hollanders na het accoord (1620). De eersten zenden schepen naar de Specerij-eilanden om factorijen te vestigen. Tocht van Coen naar de Banda-eilanden. Verovering van Lontor (8 Mart 1621). De Bandaneezen geven rich over. Wreedheden van Coen. Marten Sonck, tot gouverneur van Banda benoemd, helpt de Bandaneezen uitroeien (1621-22).

Wij hebben Martin Pring verlaten in Straat Sunda, op weg naar Bantam, toen hij de tijding ontving van de gesloten overeenkomst. Coen voer hem met de Hollandsche vloot te gemoet, en saluutschoten van weerszijden verkondigden aan de Javanen, dat de strijd tusschen beide natieën beslecht was. Den 22 April 1620 kwamen beide vloten voor Bantam ten anker. De bevelhebbers zonden eenige kooplieden met gevolg aan land om den Pangeran kennis te geven, dat zij nu vereenigd waren en met hem een handelscontract wenschten te sluiten. Aria Manggala weigerde hun gehoor te verleenen, en toen zij nog eens terugkwamen, werd hun het landen belet. Er schijnt toen over gedacht te zijn, misschien alleen van Engelsche zijde - althans wij vernemen het van dien kant - , om Bantam het lot van Djakatra te doen ondergaan, maar de Engelsche kooplieden steunden dat plan niet; hun doel was vreedzame handel, geen oorlog met Bantam. Zij waren nu echter genoodzaakt zich voorloopig te Batavia te vestigen en met hunne schepen aan de blokkade van Bantam deel te nemen. Op hun voorstel in den Raad van defensie werden nog meer dan eens pogingen aangewend om den Pangeran tot andere gedachten te brengen, maar te vergeefs. Zijn eerste eisch bleef: ontruiming van Djakatra. In October werden dus de Engelschen, die nog te Bantam waren achtergebleven, naar Batavia teruggeroepen ${ }^{1 .}$

Toen Coen aan Pring bij de mededeeling van het gesloten verdrag te kennen gaf 2: "God geve dat wij dit lang gewenschte accoord, na zoo menig jaar van twist eindelijk getroffen, in alle vreedzaam-

1 Pring bij Purchas, p. 241; Journaal van Pt. van den Broecke, p. 97 ; De Jonge, Inl. p. CXXVIII; Calendar II, No. 841, 843, 844, 879 b, 981 ; Coen aan Bewindh. 26 Oct. 1620.

2 Coen aan Pring, 10 April 1620. 
heid, vereeniging en liefde met elkander mogen ingaan en te werk stellen," mag hem dit ernst geweest zijn, maar toch alleen onder voorbehoud dat de Engelschen zijn gezag erkenden. "'T zal ons recht vrij goed maken dat wij 't hecht in handen hebben", schreef Pieter de Carpentier aan Bewindhebbers ' en daarmede vertolkte hij Coens gedachten. Het eerste bevelschrift, dat deze na de vereeniging aan de Gouverneurs der Specerij-eilanden toezond, hield dan ook wel den last in om bloedstorting tusschen Hollanders en Engelschen te voorkomen, maar met de bijvoeging "zonder nochtans van ons recht, prerogatief of autoriteit af te wijken of iets aan hen te cedeeren, volgens order u voor dezen gegeven." 2

Het duurde dan ook niet lang of de Engelschen ondervonden, dat Coen ook ten hunnen opzichte "even absoluut meester was als Koning Jacobus in Engeland" en niet gezind tittel of jota van wat hij eens verkregen rechten noemde prijs te geven. Zeer juist schreef de Engelsche president Richard Fursland van de Hollanders ${ }^{3}$ : "Zij zullen ons gebruiken om in 't bezit te komen van de plaatsen die zij wenschen, en ons laten betalen wat zij verkiezen." Coen had onmiddellijk gezien hoe hij de bepalingen van "t accoord in zijn voordeel zou kunnen gebruiken. Den 28 April, toen de vloten nog voor Bantam lagen, werd op zijn voorstel besloten tot een gezamenlijken tocht naar de Philippijnen om den Chineeschen handel op Manila te beletten. Vijf Engelsche en acht Hollandsche schepen werden daartoe bestemd. Bij de overmacht van schepen, die de Hollanders bezaten ${ }^{4}$, was het voor hen van veel minder beteekenis acht schepen te missen dan voor de Engelschen vijf, en de macht der laatsten werd daardoor aanmerkelijk verzwakt. Bij het accoord was er op gerekend, dat de Engelschen en Hollanders de voordeelen van den peperhandel te Bantam gelijkelijk zouden genieten, maar niet dat die handel hun verboden en Bantam geblokkeerd zou moeten worden, en natuurlijk eischte Coen dat beiden die blokkade (die alleen diende om Batavia groot te maken) zouden bekostigen. Op de Specerij-eilanden, dit wist de Engelsche Compagnie en daarom had zij heftig geprotesteerd

1 Brief van 8 Januari 1621.

2 Coen aan Fred. Houtman e. a., 31 Mrt. 1620.

$s$ Den 15 Oct. 1620. Calendar, II, No. 879 b.

4 Bewindhebbers hadden in 1619 eene vloot van 14, in 1620 van 20 schepen uitgerust, te veel naar den zin van Coen, die wat minder schepen doch meer volk en meer geld gewenscht had. Uit Engeland werden in 1620 zes schepen uitgezonden, 4 naar Sumatra en 2 naar Bantam. 
tegen die bepaling, zou zij feitelijk afhankelijk zijn van de Hollandsche, omdat het haar verboden was daar eigen forten te bouwen. Maar nu Bantam voor haar gesloten was en Batavia het gedwongen hoofdstation van hare agenten werd, moesten zij zich ook hier geheel onderwerpen aan de wetten die Coen geliefde te maken en de rechten die hịj geliefde te eischen. Waarschijnlijk zou, als een milder man dan Coen aan 't hoofd had gestaan, die hun met behoud van 't gezag matige voordeelen had gegund en hen niet telkens op kleingeestige wijze hunne minderheid had doen gevoelen, de toestand niet aanstonds zoo gespannen zijn geworden als nu, maar-wij moeten in 't oog houden dat de toestand van den beginne vicieus was en dat, al mocht men de Engelschen in kleinigheden zijn tegemoet gekomen, hunne grieven, waarvan het accoord zelf de schuld was, niet weggenomen konden worden.

Er was nog iets wat de goede verstandhouding tusschen Coen en de Engelschen in den weg zat. Bij de laatsten, handelaars en zeelieden, was volslagen gebrek aan tucht. Wij behoeven de brieven van hun President slechts door te zien om ons daarvan te overtuigen. Voortdurend klaagt hij dat hem door de Compagnie geen gezag genoeg is toegekend; de scheepsbevelhebbers doen wat zij willen; het scheepsvolk gedraagt zich onbeschoft, slaat telkens aan 't muiten; zijne onderhoorigen gehoorzamen hem niet. Ook heeft hij gebrek aan bekwame personen die tegen de Hollanders op kunnen. Zij hebben veel meer kennis en ondervinding dan wij, schrijft hij, "they are too hard for us." Dat Coen die lieden beneden zich achtte en vreesde dat zij misbruik zouden maken van 't geen hij oogluikend toestond, was geen wonder.

Maar de schuld lag niet alleen bij het volk, zij lag voor een groot deel bij de Compagnie. De Engelsche Compagnie had te veel omvat en kon hare verplichtingen niet nakomen. De Engelschen werden zoo slecht voorzien van het noodigste, zoowel in de factorijen als op de schepen, dat zij soms genoodzaakt waren dit van de Hollanders te koopen. Het duurde dan ook niet lang, of zij beseften het onhoudbare van den toestand en schroomden niet dit hunne principalen onder het oog te brengen. I

In December 1620 kregen de Engelschen eindelijk eenige versterking hunner scheepsmacht en konden zịj vier bodems naar de Specerij-

1 Vergelijk de brieven van Coen bij de Jonge, IV, 208-10, 216-17, 250, met die van de Engelsche presidenten Brockedon en Fursland: Calendar II, No. 878,879 b, 883, 899, 914, 942, 982, 1172 . 
eilanden uitzenden. Coen had een tijd lang geaarzeld of hij zijne plannen ten opzichte van die eilanden, zoo als ze vóór de vereeniging met de Engelschen beraamd waren, zou doorzetten. Maar nu was er geen tijd te verliezen. In den Raad van defensie sprak hij van zijn voornemen om "den algemeenen staat van de Molukken, Ambon en Banda te verzekeren", zonder in bizonderheden te treden, en vroeg aan de Engelschen of zij aan een tocht daarheen wilden deelnemen. Fursland en de zijnen verontschuldigden zich omdat hun macht te gering was. 1 Waarschijnlijk wilden zij hun weinige schepen niet afstaan voor een tocht, waarvan zij het doel wel konden gissen, en daarin kan men hun geen ongelijk geven. Die weigering was Coen naar den zin. De Raad besloot nu, dat hij zelf met 12 schepen, bemand met 1500 koppen, "innewaarts" zou varen, vergezeld door Frederik Houtman en - omineus teeken - door den fiskaal Martin Sonck. 2

Den 13 Januari 1621 van Batavia vertrokken, kwam Coen met de vloot een maand later voor Ambon. Aan den gouverneur Van Speult en aan Jam, den gouverneur der Molukken, werd last gegeven om de Engelschen (die zich eerst naar Makassar begeven hadden), als zij hier kwamen streng op de vingers te zien, hun niet toe te staan versterkingen te maken of huizen te bouwen en "met de administratie der justitie voort te gaan zonder in aanmerking te nemen of de misdadiger in dienst der Engelsche of van onze Compagnie uitgevaren zij." Zelfs moest aan hunne predikanten verboden worden "iemand van onze onderdanen" te doopen of te trouwen. 3 Voorts gaf Coen last de nagelen zooveel mogelijk op te koopen, voordat het het tractaat werd afgekondigd!

Toen hij gereed stond naar de Banda-eilanden te vertrekken, kwam kapitein Hitu met zijne zonen hem verzoeken mede te mogen gaan, daar de Bandaneezen zijne tusschenkomst hadden ingeroepen om een accoord te maken. Coen ried het hem af, want een accoord strookte geheel niet met zijne plannen, maar op zijn aandringen werd het hem toegestaan. Nadat het grootste deel der vloot hem was voorgegaan, kwam Coen den 27 Februari voor Nera. Kapitein Hitu beijverde zich nu de Bandaneezen en Hollanders tot elkander te brengen, maar zijne pogingen stuitten af op den eisch van Coen om op de voornaamste plaatsen een fort te maken. Ook de Engelschen op Pulu Run, die van Ambon uit verwittigd

\footnotetext{
1 Coen aan Bewindh., 8 Jan. 1621. Vgl. Calendar II, No. 990, III, p. 198.

2 Resol. 24 December 1620.

3 Particulier Advys en Ordre aan de Gouverneurs etc., 23 Febr. 1621.
} 
waren van Coens plan om Lontor te veroveren, sprongen voor hen in de bres. Robert Hayes schreef aan Coen, dat de Lontoreezen hun land aan den Koning van Engeland hadden afgestaan en dat hij er eene factorij had gevestigd. Hij verzocht dus den Generaal geen verdere maatregelen te nemen voor de komst der Engelsche schepen. De vruchten van Lontor kon hij immers door hunne bemiddeling bekomen. Dit laatste was grootspraak, want de Engelschen hadden niet kunnen beletten dat de meeste noten naar elders vervoerd werden, maar al was dit niet het geval geweest, de Engelschen in 't bezit der factorij te Lontor laten wilde hij niet. Vooreerst strookte dit niet met zijne plannen, maar dan ook achtte hij zich daartoe naar de letter van 't contract' niet verplicht. Hij liet dus aan Hayes zeggen dat de Raad van defensie te Batavia al op de zaak had gelet, dat door haar was goedgevonden dat hij dezen tocht zou doen en dat Hayes' landgenooten, als zij konden, hem geholpen zouden hebben. Hij verzweeg natuurlijk, dat de Raad van defensie evenmin wist wat hị in zijn schild voerde als dat Hayes een contract had gemaakt met de Lontoreezen. Hayes werd bovendien gewaarschuwd dat de Engelschen, die Coen te Lontor vond, evenmin genade zouden vinden als de inwoners. Hetzij Hayes deze boodschap ontving of niet 1, hij wilde niet dat de factorij te Lontor door de zijnen werd verlaten, al waren zij niet in staat de Lontoreezen hulp te verleenen. ${ }^{2}$ Misschien vertrouwde hij dat Coens poging om Jontor te veroveren even als die zijner voorgangers op de ongenaakbaarheid der forten zou afstuiten.

Toen de Hollanders al hun macht bijeen hadden, 10 à 1100 strijdbare mannen, waarbij twee compagnieën Japanners, eene compagnie Siauwers van Pulu Ai en eenige vrijlieden van Ambon onder 't bevel van den wakkeren Marten Jansz Visscher, in de wandeling kapitein Vogel genoemd, werd tot eene landing besloten.

De geheele strijdmacht werd den 8 Maart aan de noordzijde van 't eiland, tusschen Kombir en Ortattan aan land gezet en marcheerde nu het strand langs naar Lontor. Maar al spoedig bespeurde men dat dit ondoenlijk was, want de Bandameezen hadden op de hoogten, die den weg bestreken, geschut geplant, en het eenige pad naar boven was door borstweringen gedekt. Goede raad was duur en men

1 Hij zegt in rijn journaal (bij Purchas p. 682) geen antwoord van Coen ontvangen te hebben maar bedoelt waarschijnlijk geen brief. Vgl. de depositie van R. Randall in Calendar III, p. 53.

2 Het Engelsche geschut was hun vroeger verstrekt. Zie hiervoor bl. 236. 
besloot terug te gaan en zich weder in te schepen. De Bandaneezen lieten dit vrij toe, maar niet zonder de onmacht hunner aanvallers te bespotten.

Coen had een dertigtal tinggangs of Javaansche roeibooten medegebracht, waarmede nu nogmaals het eiland werd omgevaren om te onderzoeken waar men het best zou kunnen landen. Daarop werd een nieuw plan van aanval vastgesteld. Den 11 Maart stak een deel der troepen naar de vroegere landingsplaats over, terwijl Coen met een paar schepen Lontor beschoot. De overigen, onder aanvoering van Frederik Houtman voeren in de tinggangs naar den zuidwesthoek van 't eiland, waar een Bandaneesche overlooper hun een pad zou wijzen dat naar de boven gelegen kampong Lontor leidde. Hierop waren de Bandaneezen in 't geheel niet verdacht. Zij meenden dat de tinggangs het eiland weder zouden omvaren, zooals zij reeds driemaal gedaan hadden, en vermoedden niet dat er plan bestond op eene landing van dien kant. Zij waren dus met alle macht naar de noordzijde getogen, waar de landing vroeger geschiedde en hadden slechts enkele schildwachten bij Lontor achtergelaten. Het kostte dus Houtman en de zijnen geen moeite de kampong van achteren binnen te komen. V reeselijk ontsteld vluchtte al wie zich daar bevond, en wie het niet gelukte te ontsnappen, werd gedood. De Engelschen, die men in de factorij aan het strand vond, werden te nauwernood uit de handen der Japanners gered, maar niet als vrienden behandeld.

Eenige uren te voren had kapitein Vogel met zeventig uitgelezen soldaten bij de landingsplaats aan de noordzijde de hoogte beklommen. Tot driemaal toe sloegen de Bandaneezen hen terug, totdat Vogel en de zijnen al hun kruid verschoten hadden en een bode naar het strand moesten zenden om hulp. Deze hulp kwam bij tijłs opdagen. $\mathrm{Nu}$ trokken de Bandaneezen in de bosschen terug en lieten aan de Hollanders het bergpad naar Lontor vrij. Zonder verderen tegenstand bereikten zij die kampong en troffen er Houtman en de zijnen aan. Vogel had de eer van den dag en ontving met de zijnen een goede belooning.

De Bandaneezen verlieten nu al hun kampongs aan de westzijde van 't eiland. Deze waren onderling door fortificaties verbonden, zoodat het de Hollanders bijna onmogelijk zou geweest zijn ze te veroveren als ze goed verdedigd waren geworden. Thans vielen ze nagenoeg zonder strïj in hunne handen.

Den volgenden dag kwamen uit naam van de bewoners der overige kampongs op Groot Banda en van het eiland Rosengein I eenige

\footnotetext{
${ }^{1}$ In Coens brief aan Bewindh. (zie later) wordt het voorgesteld alsof die van
} 
Orangkaja's bij Coen om den vrede te verzoeken. De Generaal stelde tot voorwaarde, dat zij hunne sterkten en muren zouden slechten, hunne wapenen uitleveren, aan het strand komen wonen op plaatsen die men hun zou aanwijzen en de Staten-Generaal als hun Souverein erkennen; de levering van noten en foelie zou natuurlijk alleen aan de Hollanders en hunne bondgenooten mogen geschieden. Na eenige aarzeling besloten zij aan die voorwaarden te voldoen.

$\mathrm{Nu}$ moest ook Pulu Run onderworpen worden, en te spoediger omdat Coen in 't onzekere was, hoe de Engelschen hem daar zouden ontvangen. Tot nu toe was daar slechts een hunner schepen (the Star) aangekomen, doch men verwachtte den commandeur Humphrey Fitz-Herbert, die zich aan de kust van Celebes had opgehouden om Portugeesche jachten van rijst te berooven. De kooplieden van "the Star" waren naar Nera overgestoken om met Coen over den handel te spreken, maar deze had hun gezegd dat zij er wel later van zouden hooren.

Den 20. Maart stak Coen met al het kleine vaartuig en 500 man naar Pulu Ai over en den volgenden dag zond hij die macht onder Marten Sonck naar Pulu Run om het eilend op te eischen. De Orangkaja's vroegen hierop aan de Engelschen of zij hen steunen wilden; in dat geval zouden zij hun eiland tot het uiterste verdedigen. En werkelijk zou het bijna ondoenlijk zijn geweest om hen van hunne rotsen, die zij met rotangladders beklommen en waarop zij geschut geplant hadden, te verdrijven. Maar Hayes was geen Courthope en weigerde. $\mathrm{Nu}$ staken zij op verschillende plaatsen vredevlaggen uit, zoodat Sonck. eene landing onnoodig achtte, de troepen terugzond en alleen met zijn gevolg en een tolk achterbleef om met de hoofden te spreken. Hij gaf hun te kennen, dat het met hen zou gaan als met de Lontoreezen, indien zij den Generaal hunne onderwerping niet kwamen aambieden. Een paar dagen later staken de Orangkaja's naar Pulu Ai over, en nu werd op ongeveer dezelfde voorwaarden als met de inwoners van Groot-Banda (Selama c. s.) de vrede met hen gesloten ${ }^{1}$. Sonck werd nu weder met eenige soldaten naar Run gezonden om toe te zien, dat de inwoners hunne muren en verster-

Run te gelijker tijd den vrede verzochten, waarschijnlijk omdat hij niet wilde bekennen, met het oog op verwikkelingen met de Engelschen, dat hij hen met de wapenen daartoe had genoodzaakt.

1 Zie deze voorwaarden, die eerst den 9 Mei onderteekend werden, in mijne Bouwstoffen p. 284-89. Daarin wordt gesproken van de Orangkaja's van Pulu Ai en Pulu Run, daar zoo als men weet de inwoners van Ai meerendeels naar Run waren uitgeweken. 
kingen sloopten en hunne wapens uitleverden. Het Engelsche geschut werd van de rots naar beneden geworpen en de Hollandsche vlag geheschen. Alleen het kleine fort op Nailaka, het onbegroeide eilandje door een rif aan Pulu Run verbonden, bleef in handen der Engelschen, maar Coen verbood dat hun daar noten werden gebracht.

Twee dagen na de overgave van Run kwam Fitz-Herbert voor het eiland. Verontwaardigd over Coen's handelwijze, stak hij naar Nera over en vroeg hem wat hij verlangde: oorlog of vrede; wenschte hij den vrede, dan verzocht hij de dienaren der Compagnie die men te Lontor gevangen genomen had in vrijheid te stellen en de genomen goederen terug te geren. $\mathrm{Na}$ veel hooge woorden werden de gevangenen uitgeleverd en de vrede tusschen de Compagnieën afgekondigd. Coen eischte nu een viertal overloopers op, die zich op Fitz-Herberts schip bevonden, en trachtte hem door onthouding van alle verversching daartoe te dwingen, maar de Engelschman zond hen heimelijk weg; hij vond het al erg genoeg dat hij zijne oude bondgenooten in den steek moest laten. Met achterlating van twee schepen om de factorijen, die hij hier volgens de voorwaarden van 't accoord gevestigd had, van goederen te voorzien en noten te laden, voer hij naar Ambon terug.

Coen had te Lontor, dadelijk na de verovering, een begin laten maken met het bouwen van een fort om veilig te zijn tegen een overrompeling, want de gevluchte Lontoreezen, die zich nu in het oostelijk gebergte versterkten, zouden natuurlijk geene gelegenheid verzuimen om hunne oude woonplaatsen te heroveren. Zij hadden wel even als de overige Bandaneezen genade verzocht, maar waren traag in het voldoen aan de voorwaarden : uitlevering hunner wapenen en van de zonen der voornaamste Orangkaja's als onderpand. Dit was het juist wat Coen wenschte, want waren zij die voorwaarden nagekomen, dan had hij zijn plan om hen uit het land te verdrijven moeielijk ten uitvoer kunnen brengen 1. De meerderheid van zijn Raad had die verdrijging tot nu toe afgekeurd, en de Orangkaja's van Selama, Wajer enz., om advies gevraagd, hadden geraden dat men de Lontoreezen onder de overige Bandaneezen zou verdeelen, op voorwaarde dat deze voor hunne onderdanigheid aansprakelijk bleven. Maar toen de Lontoreezen steeds uitvluchten zochten en ook

1 Den 11 April schrijft Coen an Van Speult: "de vreese isser so in dat het schijnt ons voldoen sullen. "T gaet buiten mijn gissinge, want hadde liever gehadt dat weygerich bleven, om de Lontoresen met recht uyt het landt te mogen drijven en verseeckerder staet te becomen. Dan, de wille Godts moet geschieden en na de go ldelijcke schickinge moeten ons voegen." 
die van Selama en hunne bondgenooten met het afbreken hunner huizen in het gebergte talmden, werd Coen ongeduldig, en eindelijk kreeg hij 't zoo ver dat de Raad besloot om, des noods met geweld, zich van de Lontoreezen meester te maken, en indien die van Selama "en hun consoorten" daarbij geen hulp verleenden, "dat men ook hen al te samen voor vijanden zou verklaren en met geweld aantasten."

$\mathrm{Nu}$ was het lot der Bandanezen beslist. Den 20 April stak Marten Sonck met vijf compagnieeën soldaten naar Selama aan den oosthoek van Groot-Banda over, klom den berg op en bezette de kampong, een der voornaamste van het eiland, waar zich een schoone moskee bevond, die de bewondering der Hollanders opwekte. De Orangkaja's van Selama verklaarden zich bereid hun best te doen om de Lontoreezen te bewegen naar beneden te komen en bewerkten dat al spoedig 340 hunner aan boord van de Hollandsche schepen gebracht konden worden. Natuurlijk ging het niet gemakkelijk al die lieden op eens over te halen zich aan de genarle der Hollanders over te leveren; ook wenschten - althans dit verhaalt Coen - de Selammers uitzondering te maken voor de vroegere bewoners van de eilanden Nera en Pulu Ai die zich onder de Lontoreezen bevonden. Die aarzelingen, gevoegd bij onbestemde beschuldigingen dat de Selammers verraad wilden plegen - Coen zag in hen niet anders dan schelmen waren genoeg om tot uiterste maatregelen over te gaan. Reeds den 24. April, dus eerst drie dagen na de opeisching, liet hij zijn Raad besluiten ', "dat men die van Selama, Wajer en Dender zoowel als die van Lontor en consorten zal zien met geweld van land te krijgen en te vervoeren waarheen het den Generaal zal believen."

$\mathrm{Nu}$ ging Coen zelf aan land om de noodige orders te geven en liet Sonck met vijf compagnieën soldaten de Selammers omsingelen en naar het strand geleiden, vanwaar zịj op de schepen werden gebracht. Die van Wajer, Dender en Kombir, ziende wat hun te wachten stond, verlieten hunne dorpen en voegden zich bij de Lontoreezen in 't gebergte. Ook vele bewoners van Rosengein verlieten hun eiland en sloten zich bij heń aan. Coen liet nu zoowel op Groot Banda als op Rosengein al de kampongs die men bereiken kon verbranden en veruielen.

Men had nu 1200 Bandaneezen op de schepen, waarvan er 800 werden vooruitgezonden naar Batavia. Maar een grooter aantal bevond

1 Frederik Houtman was een paar dagen te voren naar Ambon gezonden. 
zich nog in 't gebergte. Te wachten tot die allen van gebrek en ellende waren omgekomen, zou te lang duren, al was de sterfte onder hen reeds groot, en toch wilde Coen niet gaarne vertrekken, zoo als hij aan Bewindhebbers schreef, voordat het spel geëndigd was. Hij liet dus den 2 Mei door een deel zijner troepen een verkenningstocht in 't gebergte doen, maar de Bandaneezen vielen hen met zulk een woede aan dat zij in wanorde op de vlucht sloegen. Ook vernam men, dat zij drie verschansingen boven elkander gemaakt hadden, zoodat het voor 't oogenblik ondoenlijk was hen met geweld van daar te krijgen.

Thans poogde Coen door middel van kapitein Hitu en de Orangkaja's van Pulu Run nogmaals met hen te onderhandelen. Maar aan den eersten eisch: overgave hunner wapenen, wilden zij niet meer voldoen. $\mathrm{Zij}$ wisten nu te goed wat zij van de Hollanders te verwachten hadden.

Intusschen had aan boord der schepen een andere tragedie plaats. Als de gevaarlijkste Bandaneezen beschouwde Coen hunne hoofden of Orangkaja's en 45 hunner had hij achtergehouden, toen de overigen naar Batavia vertrokken. Dat zij den dood verdiend hadden, was iets wat voor hem van zelf sprak, maar waarschijnlijk waren er in zijn Raad die hen nog tot op zekere hoogte verontschuldigden, hen althans niet zonder vorm van proces uit de wereld wilden helpen. Er werd nu een rechtbank benoemd, die moest onderzoeken of zij na hunne overgave voorgenomen hadden verraad te plegen. Men meende hiervan namelijk op het getuigenis van een jongen, zoon van een Orangkaja, zekerheid te hebben. Om de bewijzen te vinden, werden nu de Orangkaja's gepijnigd, zoo geweldig dat twee hunner bezweken. Anderen bekenden wat men wilde. Dit was genoeg om hun schuld aan te nemen. $\mathrm{Zij}$ werden allen onthoofd en gevierendeeld.

Coen deed niet anders dan de orders zijner principalen opvolgen. Reeds in 1615 hadden zij Reynst bevel gegeven "de Bandaneezen te vermeesteren, de principaalste uit te roeien en te verjagen en 't land liever met heidenen te peupleeren." I Maar toen zij de tijding ontvingen, dat hun bevel naar de letter was ten uitvoer gebracht, ontstelden zij toch. "Laat het eens en genoeg wezen", schreven zij aan Coen. ${ }^{2}$ "Wij hadden wel gewenscht dat het met meer gematigde middelen had kunnen beslist worden. Zij hebben hun voorgaande

1 Bewindh. aan Reynst., 30 April 1615.

2 Bewindh, aan Gcur. Gen. en Raden, 14 April 1622. 
trouwloosheid duur genoeg betaald. 't Zal ontzag maar geen gunst baren." Gunst? Wij zien een glimlach op 't gelaat van den ijzeren man. "Alsof van Mooren ooit gunst te wachten ware."

Daar de regenmoesson intrad, moest men er voor 't oogenblik van afzien de vluchtelingen in 't gebergte te bestoken. Coen besloot nu zes schepen en het noodige garnizoen hier achter te laten om er een eind aan te maken. Verscheidene plaatsen werden met tinggangs bezet om den toevoer naar de weerspannigen te beletten. Martin Sonck was reeds den 14 April tot gouverneur van Banda benoemd in plaats van Willem van Antzen, wiens ziekelijk gestel hem voor dien post ongeschikt maakte. Toen Coen den 16 Mei naar Ambon vertrok, liet hij hem het bevel achter om "den oorlog voort te zetten totdat "(de Bandaneezen in 't gebergte) "ten eenenmale ten onder gebracht en uitgeroeid zijn" en om de Orangkajas die hij in handen kreeg "met den dood te straffen." ' Hij kende zijn man en wist dat deze geen menschenlevens telde, ook niet van zijn eigen soldaten.

Te Ambon gekomen, gaf hij den Gouverneur Van Speult bevel nog acht tinggangs met 160 goed gewapende manschappen naar Banda te zenden. "De gelegenheid die God mij met kwaad weder benomen heeft", schreef hij aan Sonck, "zal u door den Almachtigen in den aanstaanden drogen moesson gegeven worden. Ziet wel toe dat zij $u$ niet ontvluchten en ontziet $\mathrm{u}$ niet allen te samen voor de eer en den welstand van 't vaderland te sterven." 2 Dit is weder een van die karakteristieke uitingen van Coen, die den man teekenen. Hij was geen huichelaar. Het belang der Compagnie (zoo als hij dat verstond 3 ) was voor hem zoo saamgeweven met de eer van zijn land en het geloof aan zijn God - den wrekenden God van 't oude Israël - dat hij werkelijk meende voor beiden strijd te voeren door de bewoners van den Archipel het brood uit den mond te nemen en, als zij zich dit niet gewillig lieten doen, hen eenvoudig om hals te brengen.

Van de ellende, die de Bandaneezen in het gebergte uitstonden, kunnen wij ons eenig denkbeeld maken door Sonck's eigen verklaring dat het er ongeloofelijk koud was, dat'er een kille mist heerscht "als bij ons in den winter." De levensmiddelen waren uitgeput. Men

1 Ordre aan Sonck, 16 Mei 1621.

2 Coen aan Souck, 23 Juni 1621.

${ }^{3}$ De Heer Van der Chijs heeft er reeds op gewezen dat de Compagnie bij de uitroeiing der Bandaneezen geen baat vond. 
had twintig prauwen getimmerd om elke gelegenheid tot ontvluchten waar te nemen; het doel was Ceram Laut en omliggende eilanden waar al velen hunner een toevlucht hadden gezocht .1 Den 27 Juni kwamen twintig korakora's van daar, en Sonck kon door stormweder niet beletten dat zij het eiland aandeden en 2 à 300 personen medenamen. Waarschijnlijk bleef het daarbij niet. In Augustus vernam Van Speult dat het aantal weerbare mannen uit Banda ontvlucht, en die zich in den omtrek bevonden, op 1100 werd geschat. Hij meende dat men 1100 zielen moest rekenen ${ }^{2}$. Hoe dit zij, toen het weder gunstiger werd en Sonck den 6 Juli met 400 soldaten (de overige waren ziek) het gebergte beklom, kostte het hem geen moeite de sterkten bij Selama en Wajer te veroveren. De meeste Bandaneezen, schrijft hij, waren van honger en ellende gestorven. De rest werd gedood of gevangen genomen. Coen zelf schat het getal omgekomenen in 't geheel op 2500. Na zijn vertrek had men nog 450 lieden van Groot-Banda en 150 van Rosengein in handen gekregen. Ze werden als slaven in dienst genomen.

Thans kon Sonck de schepen wegzenden. Een garnizoen van 550 man bleef op de Banda-eilanden achter.

Van de weggevoerden naar Batavia waren in November 1621 nog 650 personen in leven, in Januari 1622 nog slechts 524 . Zij konden daar niet aarden en smachtten om naar hun land terug te keeren. Geen wonder dat sommigen pogingen deden om daartoe hulp te bekomen van hun geloofsgenooten op Java. Toen Coen dit bespeurde, liet hij hunne Orangkaja's op de pijnbank leggen en, op hun eigen schuldbekentenis (zoo als hij schrijft), 13 hunner vierendeelen en 4 . onthoofden; al de overige mannen werden nu als kettingslaven gebruikt ${ }^{3}$, de vrouwen en kinderen naar Banda teruggezonden om aan de "burgers" te verkoopen of aan andere slaven te koppelen. Het is mij niet duidelijk of Sonck een deel hunner aan lieden van de Kei-, Aru- en Tenimber-eilanden, die te Banda sagu kwamen brengen, verkocht; het schijnt dat hij dit deed, omdat zij toch anders met hen gevlucht zouden zijn 4. Ook de inwoners van Pulu Run,

1 Van Speult aan Coen, 17 Juli 1621. (Mededeeling van een gevluchten Bandanees, met de pijnbank bedreigd): "Wilden vluchten naar Sijlon, een eiland aan 't noordeinde van Ceram." Over "Sijlon" zie Valentijn, II, 1, p. 61.

2 Van Speult aan Bewindh., 31 Aug. 1621.

3 Op de vloot die in 1622 naar China ging dienden 100 hunner als roeiers.

4 Zie Bouwstoffen enz. bl. 264. 
die volgens contract met Coen vrij in hun land mochten blijven, poogden die arme lieden tot zich te nemen, 't geen natuurlijk Coens argwaan opwekte. Dit restje vrije Bandaneezen bleef hem een doorn in het oog. "Houd gestadig het oog op die van Pulu Run," schreef hị aan Sonck, "en ontlast u van alle Bandaneezen die eenig kwaad zouden mogen berokkenen of doen kunnen." Weldra kon Sonck zijn meester geruststellen. In Juli 1622 werd hem door een jongen aangebracht dat de Orangkaja's van Run met al hun volk voorgenomen hadden hun eiland te verlaten en twee soldaten, die daar de wacht hadden, te vermoorden. Nu werd weder de pijnbank te baat genomen om eenigen hunner, die Sonck in zijn macht had, tot bekentenis te dwingen. Het schijnt, dat althans het voornemen om naar Ceram te vluchten werkelijk bestond, en er was reden voor, want zij leden honger; de Hollanders lieten 't hun aan het noodige ontbreken. Sonck liet nu al het volk van beide eilanden oplichten en in verzekerde bewaring nemen. De schuld van de Rossingeiners, heette het, was niet bewezen, zoodat alleen die van Run het ditmaal moesten ontgelden. Het klinkt ons bijna ongeloofelijk, maar alle vrije lieden, 160 in getal, werden, zoo als men het noemde "met den dood gestraft"; de vrouwen mochten met hun slaven op Groot-Banda gaan wonen, de kinderen werden naar Pulu Ai gebracht om "school te gaan". Coen was zeer tevreden over dit bedrijf van zijn handlanger; het speet hem slechts, dat niet aan de Rossingeiners en andere Bandaneezen die zich nog op de eilanden bevonden even parate executie gedaan was.

De Engelschen hadden hun fortje op Nailaka, dat tot niets diende, weldra verlaten ${ }^{1}$. Zij bleven voorloopig naast de Hollandsche factorijen ook de hunne aanhouden, maar hun inkomsten werden natuurlijk meer dan verslonden door hun aandeel in de kosten. Ook werden ze door de Hollanders niet meer dan geduld en mochten niets doen, geen kokosnoot plukken zelfs, zonder verlof te vragen.

Dezelfde Sonck, die zich in 't executeeren zulk een volgzaam leerling van Coen had betoond, ondervond weldra dat hij zich daarop niet had te laten voorstaan. Bij eene of andere gelegenheid, misschien bij 't ontruimen van Nailaka, hadden hij en Richard Welden, de Engelsche factor, wat veel kruid verspild met eereschoten. Coen liet hem om die reden terugroepen en droeg aan Houtman of Van Speult op hem te doen vervangen. Van Speult kwam in Maart 1623 te

1 Reeds in 't begin van 1622. Sonck aan Coen, 14 Mei 1622. 
Nera en bevond dat men van dat kruid verspillen te veel ophef gemaakt had, maar hij voldeed aan Coens verlangen, nam Sonck mede naar Ambon en verving hem door den fiskaal Isack de Brune ${ }^{1}$.

${ }_{1}$ Zie over de gebeurtenissen op de Banda-eilanden in 1621-23 de door mij uitgeg. Bouwstoffen bl. 272-294, 336-344; Conqueste van het eilant Banda, in deze Bijdragen, II (1854); Coen bij De Jonge, IV. bl. 260-61; Coen aan Sonck; 28 Dec. 1622 (2 brieven); Journaal van R. Hayes bij Purchas I b, p. 682-83, Calendar II, No. 989, 990, 997, 1113; III, No. 53, 140, 143, 236; J. A. van der Chijs, De vestiging van het Ned. gezag over de Banda-eilanden (Batavia 1886) bl. 115 vv., die de gebeurtenissen in bizonderheden verhaalt, maar de Engelsehe bronneu niet heeft kunnen raadplegen. - Het bekende "Waerachtich Verhael" van 1622, meermalen nagedrukt (in de verzameling Begin en Voortgang der $0 \mathrm{I}$. Comp. tweemaal, voorts bij Wassenaer, Baudartius enz.) is blijkbaar van Bewindhebbers uitgegaan na ontvangst van den brief van Coen van 6 Mei 1621 in mijne "Bouwstoffen" opgenomen. Het is vertaald door Purchas ( $\rho .687-90)$ en wordt daar gevolgd door eene wederlegging met het oog op 't geen van de Engelschen wordt medegedeeld (p. 690-92). Het pamflet van Abraham Woofe (assistent te Lontor in 1620-21): "The tyranny of the Dutch against the English" (London, printed by $\mathrm{E}$. Crowch 1660 in $8^{8}$ ) heeft weinig te beteekenen en is onbetrouwbaar. 


\section{VIJFDE HOOFDSTUK.}

Bestuur van Herman van Speult op Ambon (1619-22). Coen verklaart Kimelaha Hidajat en de hoofden der peperplaatsen op Ceram tot vijanden. Instructie aan Van Speult ten hunnen opzichte. Manipa, Buru en Amblau onder 't Kasteel gebracht. - Bestuur van J. Dz. Lam in de Molukken (1619-21). Zwakheid der Spanjaarden. Kaitjil Ali verovert Djilolo. Lam vervangen door Frederik Houtman (1621). Coens last tot het slechten der forten wordt niet opgevolgd. Houtmans bewind door Coen afgekeurd.

Het is niet twijfelachtig of Coen had, indien hem alles was meegeloopen, in de Ambonsche eilanden op dezelfde wijze huisggehouden als op Banda. Maar ziekte en sterfte onder zijn volk, de noodzakelijkheid om een groot deel hunner op Banda achter te laten, en de voor landtochten ongeschikte tijd van 't jaar deden hem van zijn voornemen afzien $\mathbf{1}$.

Werkelijk verdroeg ook in die eilandgroep een groot deel der der inlanders noode het juk der Compagnie, en na Coens vertrek in 1619 had de gouverneur Herman van Speult moeite genoeg gehad zijn gezag te handhaven. Het was hun natuarlijk niet onbekend gebleven, dat Coen voor de Engelschen de wijk had moeten nemen en dat de Pangeran van Bantam op het punt stond de Hollanders uit hun fort te Djakatra te verdrijven. Met Van Speult aan te nemen dat de Pangeran hen opstookte, zal wel overbodig zijn. Zij hadden waarlijk geen aansporing noodig om, waar zij er kans toe zagen, hun slag te slaan.

De ziel van den tegenstand in dezen tijd was de Ternataansche Kimelaha Hidajat, of Daja, zoo als hij door de Hollanders genoemd werd. Gesproten uit een aanzienlijk geslacht, dat even veel aanspraak maakte op den troon van Ternate als het nu heerschende, en ijverig Mohammedaan, althans den Islam te baat nemende om zijn heerschzucht te bevredigen, had hij reeds in de Molukken de Hollanders tegengewerkt ${ }^{2}$, maar Prins Ali, wiens staatkunde medebracht hen te vriend te houden, was hem te machtig. Hij had dus in Maart

1 Bouwstoffen bl. 294.

2 Zie Achtste gedeelte blz. 269. 5е Volgr. II. 
1616 gaarne de opdracht van den Sultan aanvaard om met eenige korakora's naar Ambon te gaan, ten einde daar zoo noodig hulp te bieden tegen de Spanjaarden die er verwacht werden. Reael had hem zelfs in zijne uitreeding geholpen en trad in 1617, toen hij zich op Ambon bevond, met hem en Sabadin in overleg over hetgeen op Banda te doen stond 1.

Sedert stond hij Sabadin, den Ternataanschen stadhouder te Luhu, die oud en zwak was, ter zijde, en had reeds vóór diens dood (in December 1619) de teugels van het bewind in handen, hoewel tegen den zin van Ali, die hem meer dan eens deed terug roepen 2. Een ijverigen helper vond Hidajat in Kimelaha Leliato, een zoon van Sabadins voorganger Bassi Frangi, en zijn aangewezen opvolger.

Wat Kapitein Hitu betreft, wij hebben vroeger gezien dat deze de Hollanders was toegedaan, natuurlijk niet uit affectie, hoewel hij voor Van der Haghen en andere verdraagzame lieden werkelijk vriendschap mag gekoesterd hebben, maar omdat hij niet af hankelijk wilde zijn van de Ternatanen. De Hituees zocht echter ook met de laatsten vriendschap te houden, want, indien de Hollanders geheel meesters waren, begreep hij wel dat hij de voordeelen van den handel met inlandsche jonken, die hem nu nog gegund werden, zou moeten missen, en bovendien dat zijn gezag groot gevaar zou loopen, want hij was ijverig Mohammedaan en Van Speult werkte den Islam sterk tegen. Voor dezen even als voor Coen en de meesten hunner tijdgenooten waren Mohammed en Duivel hetzelfde begrip, en dus alle Mohammedanen uit den aard der zaak vijanden van de Christenen. $\mathrm{Nu}$ was het wel niet geheel ten onrechte dat hij de Mohammedaansche geestelijken verdacht van de inlanders tegen de Hollanders op te zetten, maar hij gaf er zelf aanleiding toe door hen te vervolgen en de inlanders te dwingen den Islam af te zweren. Want, waarschijnlijk door Coen's invloed, week hij meer en meer af van de politiek van verdraagzaamheid, door Reael en Van der Haghen gevolgd, die toch ook niet aarzelden de Mohammedaansche ijveraars in toom te houden. Op de plaatsen, die zooals men 't noemde onder 't Kasteel stonden, duldde Van Speult geen Mohammedaan. Te Hatu werden een moskee en een school door hem verbrand. Op het trouwen van Ambonsche vrouwen met Hitueezen of andere Mohammedanen werd

1 Resol. Reael en Raden, 27 Febr.; Journaal van Reael, 9 Mrt. 1616; Reael aan Bewindh., 10 Mei 1617; Vgl. den brief van Geron. da Silva van 1 April 1616 in: Correspondencia etc. p. 357.

${ }^{2}$ Zie Bouwstoffen bl. 264. 
een zware boete gesteld. Uit vrees gingen nu velen tot het Christendom over, en al aten zij nog zoo veel spek om hun oprechtheid te toonen, Van Speult begreep toch wel dat zij "Moorsche herten" behielden. Wat dit Christendom, waartoe ook een aantal Chineezen werden "bekeerd", beteekende kan, men opmaken uit het feit dat de eenige predikant, Sebastiaan Danckaert, zelf nog Maleisch moest leeren vóór hij eenig onderwijs kon geven. Toen hij zoo ver was, nam Van Speult den verstandigen maatregel hem op te dragen eenige jonge inlanders, die reeds school hadden gegaan, voor het godsdienstonderwijs op te leiden, hetgeen een paar jaar later ten gevolge had dat de school 300 leerlingen telde. Hoeveel meer door persoonlijken invloed van mannen van overtuiging dan door dwang kon worden tot stand gebracht, hadden vroeger de Jezuïten-zendelingen bewezen en bleek ook thans uit het voorbeeld van een Ambonees, een zoon van den pati van Hative, die door Matelief naar Nederland medegenomen en daar opgevoed was. Door dezen jongen man, die den naam droeg van Laurens Marcus, werd de pati van Alang aan den westhoek van Ambon met een deel zijner onderdanen tot het Christendom gebracht. Misschien was hij het ook, die Van Speult op het denkbeeld bracht om vier jonge Amboneezen, zoons van andere hoofden, naar Nederland te zenden om opgeleid te worden tot predikant, althans Laurens gaf hun aanbevelingsbrieven mede aan zijn vroegeren beschermer ${ }^{1}$.

Wij hebben gezien hoe in 't begin van 1619, in 't vooruitzicht van de. komst der Engelsche mededingers, Coen en Van Speult aan de hoofden der nagelplaatsen en aan Sabadin en Hidajat geschenken uitgedeeld en gunsten bewezen hadden. Van Speult had ook het fort te Luhu van geschut en bezetting voorzien, maar toen de vrees voor de komst der Engelschen ijdel bleek, zal Coen, die manschappen noodig had voor de vloot die hij tegen hen uitrustte, die bezetting wel hebben teruggeroepen. Althans later vernemen wij van Van Speult, dat de Luhueezen dat geschut als 't ware tegen de Hollanders hadden geplant en zich in den wapenhandel oefenden om het fort te kunnen verdedigen. Hoop op den steun der Engelschen en de nederlaag der Hollanders, en de zwakke macht waarover Van Speult na Coen's vertrek te beschikken had, schijnen Hidajat en de zijnen ten prikkel gestrekt te hebben om den invloed, dien Van Speult op de eilanden in den omtrek verkregen had, zooveel mogelijk te verijdelen.

${ }^{1}$ Zie over hen mijne Bouwstoffen, bl. 271 en Inl. bl. LXI-LXIII. 
Hij bewerkte dat alle Mohammedanen (de Hitueezen uitgezonderd) zich nauwer aaneensloten en zich verbonden elkander tegen de Hollanders bij te staan, als deze hen tot onderwerping wilden dwingen. Ook de dorpen aan Cerams zuidkust, die voor een deel tot den Islam gebracht waren, maar wier hoofden om de belasting aan Ternate te ontgaan zich onder de bescherming der Compagnie gesteld hadden, bezocht hij met een hongi, machtiger dan die Van Speult kon bijeenbrengen, om hen in onderwerping te houden en hen met zijn wraak te dreigen, indien zij "met den Gouverneur pangaaiden " d. i. aan diens hongi-tochten deelnamen. Van Speult mocht dit niet lijdelijk anzien. In October 1619 ging hij met een hongi op de roei, eerst naar Kambelo waar Hidajat met zijn hongi lag, en verweet hem zijn bedrijf aan de kust van Ceram. Hidajat antwoordde dat die kust onder den Sultan van Ternate stond en dat hij haar dus niet mocht afstaan. Ten bewijze beriep hij zich op de uitspraak van alle orangkaja's in den omtrek, die men bij de terugkomst van den Generaal zou vergaderen; intusschen verzocht hij dat Van Speult geen tocht zou doen naar die kust. Maar de Gouverneur liet zich niet van zijn voornemen afbrengen en voer eerst naar de Oeliasers met het plan om in de eerste plaats de bewoners van Nusalaut te straffen, wier haat hij op den hals had gehaald door hun "Moorschen paap" gevangen te nemen en naar Java te zenden, en die hem daarom de gehoorzaamheid hadden opgezegd. Maar hij bespeurde spoedig, dat hij in de tegenwoordige omstandigheden van zijne bondgenooten geen hulp te verwachten had. De Mohammedanen hadden de overhand en Van Speult was zelfs genoodzaakt op Saparua en Haruku soldaten te leggen om de dorpen zijner onderdanen tegen hun aanslagen te beveiligen. $\mathrm{Nu}$ stak hij over naar de kust van Ceram en vernam van zijne oude bondgenooten aan de Elpaputih-baai, dat zij zonder beter hulp van de Compagnie Hidajat niet konden weerstaan, hoe gaarne zij ook van hem bevrijd zouden zijn. Ook verderop aan de kust, te Toluti, waar de inwoners klaagden dat zij "bijkans ten roof van alle man" stonden, werd hem hetzelfde verzekerd.

Den 3 April 1620 bracht Frederik Houtman, die door Coen tot commandant over de scheepsmacht in de Molukken was benoemd, te Ambon de tijding van de verovering van Djakatra en het vertrek der Engelschen. "Nu was onze haan weer koning", schreef Van Speult aan Coen. De peperplaatsen op Ceram gaven zelfs een voorraad nagelen op schuld, en Hidajat noodigde Van Speult uit, bij gelegen- 
heid van het doodenfeest voor Sabadin, met hem en de verzamelde orangkaja's te bitsjaren. Van Speult gaf aan die uitnoodiging gehoor en voer, vergezeld door de hoofden zijner onderdanen, met de galei en het jacht, die hij tot zijn beschikking had, naar Luhu over. Het schijnt dat Hidajat niet op zulk een machtsvertoon had gerekend en dat verscheidene Orangkaja's zich uit vrees uit de voeten makten. $\mathrm{Nu}$ werden door Van Speult de oude grieven nog eens opgehaald, maar Hidajat hield vol, dat de Cerammers zich nooit aan de Compagnie onderworpen haden, en een van de aanwezige hoofden (van Amahee), tot getuige opgeroepen, beweerde dat, wanneer zij dit al gedaan hadden, het alleen uit vrees was geschied. Dit zal wel van de meesten waar zijn geweest, althans waar Mohammedanen het gezag uitoefenden. Ook Hatuhaha (Noordelijk Haruku), hield hij vol, had altijd tot Ternate behoord, al mocht de Gouverneur Houtman daar eenmaal een contract gesloten hebben. Over 't algemeen vond Van Speult de hoofden toch meer geneigd tot schikking dan vroeger. En met eene welwillende maar behoedzame politiek zou die verhouding waarschijnlijk nog verbeterd zijn, toen de bewoners der nagelplaatsen bij tegenstand niet meer op de hulp der Engelschen konden rekenen. Maar van den man, die, na zich van de Banda-eilanden verzekerd te hebben, den 20 Mei 1621 met een deel zijner vloot voor Hitu kwam, van Jan Pieterszoon Coen, was geen verzoenende politiek te wachten.

Toevallig lagen daar juist de korakora's van Hidajat en van de hoofden der nagelplaatsen, waarschijnlijk hier gekomen om met kapitein Hitu te bitsjaren over de vergadering aan 't Kasteel, waartoe Coen tegen zijn komst alle hoofden uit den omtrek had laten oproepen. Zij kwamen nu den Generaal aan boord hun opwachting maken en gaven voor op weg te zijn naar 't Kasteel. Toen zij Coen nadere inlichting vroegen omtrent zijne voornemens, vermeed hij daarover in bizonderheden te treden, 't geen natuurlijk, met het oog op zijne behandeling der Bandaneezen, hun argwaan wekte. Zij waren dus voorzichtig genoeg niet op de vergadering te verschijnen, die den 2 en 3 Juni plaats had, en waar 't misschien ook slecht met hen zou zijn afgeloopen, althans als de Ceramsche hoofden van de zuidkust en die van Nusalaut in Hidajat's tegenwoordigheid hadden durven verklaren, wat zij thans in zijn zijn afwezigheid deden, dat hij hen met zijn wraak gedreigd had, indien zij niet hem (of zoo als het heette den Sultan van Ternate) maar de Hollanders gehoorzaamden. Coen zond nu twee afgevaardigden naar Hidajat om hem eenige 
punten van beschuldiging voor te houden. Zij ontvingen de gewone uitwijkende antwoorden. De Cerammers had hij niet opgestookt, maar slechts bezocht als onderdanen van den Sultan ; "officiers of papen" had hij hun niet gezonden; die van Nusalaut waren hem zelven komen vragen een verbond met hen te sluiten, maar hij had dit afgeslagen en hun zelfs ontraden vijandschap te plegen tegen de dorpen die onder de Compagnie stonden. Hij zond nu ook "eenige slechte lieden", zoo als Coen schrijft, als afgevaardigden van hem en de peperplaatsen naar 't Kasteel, maar deze kwamen na afloop der vergadering en werden met de oude lijst van beschuldigingen weer naar huis gezonden. Pogingen aan te wenden tot beter verstandhouding achtte Coen even ijdel als in 't geval der Bandaneezen. Reeds den 5 Juni was bij resolutie besloten om, zoodra zich de gelegenheid aanbood, of om in Coen's taal te spreken, "als men de hulpe Gods mocht verwachten", de weerspannelingen ten onder te brengen. "Om den staat van den lande van Ambon te verzekeren," zoo luidde de Instructie, den 23 Juni 1621, den dag vóór zijn vertrek, aan Van Speult gegeven, "moeten die van **1, welke onze principaalste onderkruipers en opposanten zijn, ten eenenmale ten ondergebracht, verdreven of vernield worden. Wij vinden niet geraden zulks te ondernemen, voordat wij hen wis nemen mogen, de achterdeur gesloten zij en belet kan worden dat zij zich lang met de vlucht in 't bosch kunnen onderhouden ... Hierover zal UE. op 't allerhoogste behartigen om de achterdeur van voorsz. auteurs van 't kwaad met alzulke behendigheid te sluiten dat ons dessein door niemand bemerkt worde, gelijk wij van verre, namelijk in de Molukken, beginnende zijn." 2

Zeker is het, dat Coen door zijn bedrijf in de Banda-eilanden het voor Van Speult niet gemakkelijker had gemaakt. Niet gering was de invloed der gevluchte Bandaneezen, die zich, zoo als Van Speult schrijft, meest voor "Lebees, Imams en Pandieten" uitgaven en met het verbreiden van den Islam natuurlijk ook tegenstand tegen hunne vervolgers beoogden. In September 1621 vernam de Gouverneur dat in de kampong Wai op Ambon de helft der Christenen reeds "Moorsch" was geworden, waarop hij met soldaten al de inwoners naar ' $t$ Kasteel liet brengen en hen dwong hunne "valsche sekte" te verlaten en het Christen-geloof (!) aan te nemen. Daarop verzamelde hij een

${ }^{1}$ Natuurlijk werden hiermede in de eerste plaats de inwoners der peperplaatsen op Klein-Ceram bedoeld (Luhu, Kambelo, Lesidi enz.).

2 Vergelijk over de Molukken hierachter blz. 271. 
hongi om de Bandaneezen in hunne schuilhoeken op Ceram en de Zuidoostereilanden op te zoeken. Met 30 korakora's, waarbij zich kapitein Hitu uit eigen beweging aansloot, waarschijnlijk om zoo noodig als bemiddelaar op te treden, voer hij de kust van Ceram langs. Niet ver van den oosthoek, bij Guliguli, werd hij drie korakora's gewaar, die hem kalm bleven opwachten, zoodat hij vermoedde dat zich in haar nabijheid een aanzienlijke hongi moest bevinden. Daar het avond was, wachtte hij tot den volgenden morgen, en hoewel des nachts tien van zijn korakora's uit vrees ontsnapt waren, roeide hij met de overigen naar den vijand toe. Weldra zag hij zich door groote en kleine vaartuigen omringd, maar zij bleven op zulk een afstand dat hij met moeite een enkele korakora onder schot kreeg en aan boord klampte, waarop de Ambonners de bemanning van kant maakten. Hiermede waren zij vlug genoeg, maar met het vervolgen van de overige korakora's, die de vlucht namen, maakten zij minder haast. Van Speult stak nu de kampong Guliguli en de vaartuigen die hij daar vond in brand en maakte den volgenden dag, toen zijne vloot zich van water voorzien had, aan de Ambonners bekend, dat hij zich met hen naar het eiland Koor wilde begeven, van waar uit, zoo als hij vernomen had, gedurig rooftochten plaats hadden. Maar de Ambonners maakten zooveel bezwaren dat hij genoodzaakt was van zijn voornemen af te zien. $\mathrm{Nu}$ werd een aantal kampongs aan de Ceramsche kust, tot Werinama toe, in brand gestoken, en koers gezet naar den hoek van Kuwak, ten O. van de Elpaputih-baai. Men had besloten daar een fort te bouwen, ter bescherming, zoo het heette, van de bondgenooten der Compagnie. Doch deze waren bij de komst van Van Speult allen in de bosschen gevlucht en wilden niet aan 't strand komen. Er werd thans een houten fort aangelegd en van geschut en een veertigtal manschappen voorzien. Het ontving den naam Harderwijk. De Cerammers waren echter niet te bewegen aan het fort te komen wonen, hoewel een paar hoofden van naburige dorpen den eed van getrouwheid aflegden. Het verbranden der kampongs had natuurlijk ten gevolge, dat de bewoners van die kusten op de onderdanen der Compagnie waar zij konden weerwraak namen.

Een jaar te voren was het Van Speult gelukt een deel der bewoners van Manipa over te halen hunne nagelen aan 't Kasteel te brengen en had zich te Tuban, aan de westkust van dat eiland, een Hollandsch assistant gevestigd. Thans, in December 1621 vernam hij dat zij in groote vrees verkeerden, daar Hidajat te Boano een hongi ver- 
zamelde om hen voor den afval van zijn gezag te straffen. Van Speult liet Hidajat verzoeken van den tocht af te zien, 't geen hij weigerde. Hierop begaf de Gouverneur zich in Februari 1622 zelf met een voldoende macht naar Tuban, waar de Orangkaja's het contract met hem vernieuwden, en zond kapitein Vogel naar Hidajat, die met zijne korakora's aan de oostzijde van 't eiland lag, om hem te ontbieden. Hidajat verscheen werkelijk, "zoo gealtereerd", schrijft van Speult, "dat alles schudde en beefde wat hij an het lijf had." Maar daar de man kort daarna overleed, zal hij wel een ziekte onder de leden gehad hebben. Op de beschuldigingen van Van Speult gaf hij ten antwoord dat de Hollanders te lichtvaardig aan achterklap geloof sloegen; wat Manipa betreft, dit eiland had altijd onder Ternate gestaan. En dat hij niet op aanschrijving van Coen aan 't Kasteel was gekomen, was uit vrees geschied, "omdat er toen verscheidene praatjes rondgingen", m. a. w. omdat hij hem wantrouwde. Van Speult dreigde nu de loge te Luhu te lichten en hem als vijand te behandelen, indien hij de Hollanders bleef verongelijken, wat althans zooveel uitwerkte dat hij zich tot overleg genegen toonde en den Gouverneur uitnoodigde te Luhu te komen bitsjaren.

Het wakker optreden van Van Speult te Manipa had ten gevolge dat de Mohammedaansche hoofden van Lomaïte en Waisama, de twee voornaamste kampongs op het eiland Buru, zich bereid verklaarden met hem te onderhandelen, op voorwaarde dat men hen in hun geloof niet zou bemoeielijken. Hij ging er zelf heen om met hen een contract te sluiten, waarop ook de bewoners van 't eiland Amblau zich onder de gehoorzaamheid van 't Kasteel begaven, en Van Speult een paar manschappen naar beide eilanden zond om de belangen der Compagnie te behartigen.

Van Buru komende, bezocht de Gouverneur ook de voornaamste peperplaatsen op Klein-Ceram: Lesidi, Kambelo en Luhu, en overal deed men beloften van beterschap.

Kort na Coen was ook de Engelsche commandant Fitz-Herbert voor Ambon gekomen en had daar de noodige kooplieden achtergelaten voor de factorijen aan 't Kasteel, te Hitu, Larike, Luhu en Kambelo. Zij hadden hier al even weinig in te brengen als te Batavia en deden al spoedig dezelfde ondervinding op, dat, zoolang zij door hunne Compagnie niet beter voorzien werden, de baten niet opwogen tegen de zware lasten, waaronder zij gebukt gingen. Hoe weinig Van Speult hen van den beginne vertrouwde, blijkt uit zijne brieven aan Coen. Hij had er wel eenige reden toe, daar zij niet 
konden nalaten particulieren handel te drijven, wat hij niet mocht toestaan. Wij zullen later zien welke treurige gevolgen dit wantrouwen had 1.

"In de Molukken", zoo schreven de Engelsche kooplieden te Batavia kort na de vereeniging der Compagniën aan hunne principalen, "in de Molukken zijn de lasten door den oorlog tegen de Spanjaarden, die het onderhoud van verscheidene forten noodzakelijk maakt, overmatig, terwijl die eilanden bijna geen specerijen leveren. Ternate en Tidore in 't geheel niet. Op Tidore durven de Hollanders niet over de muren van hun fort kijken, maar bezetten die slechts om er de Spanjaarden uit te houden. De Ternatanen worden door de Spanjaarden en Tidoreezen zoodanig verontrust dat de nagelen in den grond verrotten, omdat er geen handen zijn om ze te plukken. Motir levert zeer weinig nagelen, Makian slechts 200 bahar in 't jaar, Batsjan bij gebrek aan volk niet meer dan 40. Ambon en Ceram daarentegen meer dan $1000 /{ }^{2}$. Geheel juist waren de Engelschen nog niet ingelicht. De voorname reden waarom de Ternatanen geen nagelen plukten, was deze, dat de Hollanders ze slecht betaalden en voor de kleeden die zij in ruil gaven het dubbele eischten als b. v. op de Ambonsche eilanden 3. Bovendien bleven zij in gebreke levensmiddelen aan te voeren, zoodat de Ternatanen genoodzaakt werden die elders te zoeken en zich op den bouw van rijst en mais toe te leggen ${ }^{4}$. In $\mathrm{J} 619$ heerschte er volslagen hongersnood, en het hielp al zeer weinig of Coen een jacht naar Sula zond om rijst te laden.

De zaak was, en dit begrepen de Engelschen zeker niet, anders zouden zij de dwaasheid niet gehad hebben acht of negen factorijen in de Molukken te vestigen, - dat de Hollanders, nu het meerendeel der nagelen van Ambon en Ceram hun in handen viel, die uit de Molukken niet meer noodig hadden. Bewindhebbers hadden aan duizend bahar nagelen genoeg en verlangden er niet meer. "T is beter", schreef Coen aan den gouverneur der Molukken,

${ }^{1}$ Zie over 't voorgaande: Bouwstoffen door mij uitgeg., bl. 251-271, 311-323; Coen aan Bewindh., 6 Mei 1621; Van Speult aan dez. 16 Mei, 31 Aug. 1621; Dez. aan Coen 29 Aug. 1621; Valentijn II 2, p. 43-53; Calendar, II, No. 976, 990, 1031 ; III, No. 91, 99, 143 p. 61.

2 Calendar, II, No. 883.

3 Van Speult, die dit onbillijk vindt, aan Coen, 15 Juni 1620.

4 Zie hiervoor en vgl. J. C. Grijph (directeur van den handel in de Mol.) aan Coen, 3 Mrt. 1622. 
"dat ze in 't bosch vergaan dan dat er ons meer gezonden worden 1. Men had slechts zorg te dragen dat de nagelen, die er nog groeiden, niet aan de Spanjaarden in handen vielen en dat deze geene nieuwe veroveringen maakten. Voor 't overige kon men de Spanjaarden dulden, want, zoolang zij er waren, kon men de Ternatanen beter in bedwang houden, daar deze nu de Hollanders niet konden missen. Het veroveren van Spaansche forten vonden Bewindhebbers na de vereeniging met de Engelschen ook daarom niet wenschelijk, daar zij vreesden dat deze dan volgens 't contract aanspraak zouden maken op medeeigendom 2. De Engelschen zagen dit alles eerst later in $\mathbf{3}$.

Maar het was eerst in Juni 1621 dat de Engelschen zich hier kwamen vestigen, en wij hebben de Molukken verlaten in Maart 1619, toen Reael die eilanden verliet. Lam, dien hij in November 1618 tot vice-gouverneur had benoemd, voerde hier na zijn vertrek het bewind. Met de Spanjaarden werden slechts onbeduidende schermutselingen gevoerd. Van beide kanten waren de forten voldoende tegen een aanval beschut, zoo lang men de macht niet had om doortastender maatregelen te nemen. In Februari kregen de Spanjaarden versterking onder een nieuwen gouverneur, Don Luis de Bracamonte, maar het gelukte een Hollandsch schip, dat met mondkost uit Japan kwam, een hunner vaartuigen te veroveren en een aantal Spanjaarden, waarbij aanzienlijke personen, gevangen te nemen. Deze buit was de Hollanders welkom, omdat er nu kans bestond op verlossing hunner gevangenen te Manila. Maar de Spanjaarden haastten zich niet met de uitlevering, en Coen, die Lam om zijn humaniteit mistrouwde, gelastte hem zijn gevangenen "zoo hard te tracteeren dat de vijand te Manila hun geschrei hoorde" 4.

Uit hetgeen wij ter loops in Hollandsche brieven van de Spanjaarden vernemen blijkt, dat zij het in de Molukken kwaad te verantwoorden hadden. Mondkost moesten zij zelven in den omtrek gaan zoeken. In Maart 1620 vergezelden zij, zeker met dat doel, de Tidoreezen op een rooftocht naar de Sula-eilanden. Toen zij kort daarop vernamen dat de Hollandsche Gouverneur-Generaal met een aanzienlijke vloot in de Molukken verwacht werd, besloten zij hunne

1 Van Speult aan Coen, in Bouwstoffen, blz. 324; Coen aan F. de Houtman, 28 Dec. 1622.

2 Bewindh. aan GG. en Raden, 4 Maart 1621.

3 Calendar, III, No. 370.

4 Lam aan Coen 3 Mrt. 1620; Coen aan Bewindh. in Bouwstoffen, bl. 300; Coen aan Lam; 22 Mei 1621. 
forten op Halmahera te lichten om die op Ternate en Tidore beter te kunnen bezetten. De Tidoreezen zagen dit natuurlijk met leede oogen. Hun sultan werd hoe langer hoe ongeduldiger dat de "armada", die hem zoo lang door de Spanjaarden beloofd was, niet verscheen en gaf den Gouverneur niet onduidelijk te kennen dat hij hen wel kon missen. Ook knoopte hij met de Engelschen te Makassar, die toen nog in oorlog waren met de Hollanders, onderhandelingen aan. Kort te voren zou hij eene dochter van den vorst van Gowa ten huwelijk gevraagd hebben voor zijn zoon. 1

Voor de Ternatanen was het verlaten van Halmahera het sein om op de kusten van dat eiland, die onder Tidore stonden, weder te muiten en te rooven. Djilolo had nu Tidoreesche bezetting, maar de Spanjaarden zullen het meeste geschut wel hebben medegenomen, althans Kaitjil Ali achtte de kans schoon om die plaats te veroveren. Hij verzocht slechts aan Lam dat zijne oorlogsprauwen door een Hollandsch schip tegen de Spaansche galeien beschermd mochten worden. Lam stond dit toe, en den 3 Augustus 1620 stak Ali met dertig korakora's naar Djilolo over en tastte het benedenfort aan, maar werd afgeslagen. Toen echter de bemanning van 't Hollandsche schip hem te hulp kwam, gaven de Tidoreezen eerst het benedenfort en toen ook het bovenfort over. De Ternatanen bleven die forten bezetten en versterkten ze met behulp van den Sengadji van Sabua. "Aldus", schreef Coen aan Bewindhebbers, "hebben de Ternatanen door hulp van de onzen middel gekregen om meerder moedwil tegen ons te plegen." 2 Dat wij ons bij contract verbonden hadden de Ternatanen bij te. staan, kwam bij Coen natuurlijk niet in aanmerking.

Bij de komst der Engelschen werd Lam, die hen te veel als vrienden behandelde ${ }^{3}$, uit de Molukken verwijderd en vervangen door Frederik Houtman. In een bondige instructie werd hem door Coen zijn gedragslijn voorgeschreven. Den Sultan en zijn Raad moest hij de "kwade proceduren" van Hidajat voorhouden en recht tegen hem eischen; de forten Marieko op Tidore, Kalamata op Ternate, Sabua op Halmahera slechten; de Ternatanen verbieden zonder zijne toe-

1 Lam aan Coen, 21 Apr. 1620; Coen aan Bewindh. 26 Oct. 1620; Fred. Cistiens (een van de bevrijde gevangenen) aan Bewindh., uit Batavia (?) 15 Oct. 1621; Coen in Dodt's Archief bl. 202.

2 Lam aan Chr. Stuling, fiskaal te Makian, 5, 12 Aug. 1620; Coen aan Bewindh. 26 Oct. 1620.

3 Vgl. Calendar, III, No. 137. 
stemming van de andere eilanden volk te lichten of op de roei te gebruiken; niet gedoogen dat zij vrede maakten met Tidore. Willen de Ternatanen zich op Halmahera 1 of elders vestigen, "laat hen zonder verhindering gaan en houd het volk van Makian en Motir op hun land, 't gouvernement daarover aan ons nemende." De tol voor de nagelen, dien de Sultan hief, moest van 15 op 10 pCt. worden gebracht; de Engelschen moest hij hun derde in de kosten maandelijks laten betalen. 2

Den 30 Juni 1621 kwam Houtman op Ternate, belegde een vergadering met den Sultan en zijn Raad, waaraan ook Fitz-Herbert en de Engelsche opperkoopman Nicolls deelnamen, en deelde aan de Ternatanen mede wat van hen verlangd werd. Het afbreken van Marieko bleek hun onverschillig, maar Kalamata en Toluko op Ternate waren de "poorten van Malajoe" en Sabua was hun "etenstresoor"; zij verklaarden dus in het sloopen van die forten niet te kunnen toestemmen. De eischen van Coen in verband met de uitroeiing der Bandaneezen konden niet anders dan vrees en wantrouwen wekken. Vele Ternatanen namen reeds met hun gezin de wijk naar Halmahera, en waarschuwden ook de Makianners dat er onraad dreigde. Houtman zag nu dat het roekeloos zou zijn de koord te strak te spannen, want er was kans dat niet alleen de Ternatanen hun eiland verlieten, maar dat ook de inwoners der andere eilanden die onder Ternate stonden: Makian, Motir en Batsjan, hun voorbeeld volgden en deze voor de Hollanders alle waarde verloren; de macht toch om dat te beletten bezat Houtman niet. Hij besloot daarom het slechten der forten uit te stellen, op voorwaarde dat Ali hem beloofde minstens honderd huisgezinnen te Kalamata te laten wonen, waarschijnlijk om het fort te onderhouden. Dit besluit deed de spanning eenigszins bedaren en het vluchten ophouden. 3 Alleen 't fort Marieko op Tidore werd nu door de Hollanders vernield en verlaten, zeer ten genoege van de Spanjaarden, die het dadelijk lieten herstellen en bezetten en Houtman kruid aanboden, indien hij meer forten wilde laten springen. ${ }^{4}$

Toen Lam op het punt stond te vertrekken, verzocht Kaitjil Ali hem een vertrouwd persoon te zenden, aan wien hij nog eens kon

\footnotetext{
1 Er staat "'t lant van Gilolo."

2 Instructie voor F. Houtman, gegeven te Ambon 11 Juni 1621.

3 Houtman aan Coen, 12 Juli, 14 Aug. 1621: Coen aan Bewindh. in Bouwstoffen, bl. 298. Vgl. Calendar, II, No. 1035, 1050.

4 "Rapport gedaen by verscheyden persoonenu (1622) in Kronijk Hist. Gen., 1871 , bl. 327 .
} 
mededeelen wat hij op het hart had. Lam zond hem den fiskaal Stuling, wien hij met bescheidenheid te kennen gaf dat hij tot zijn spijt bespeurd had, hoe weinig de Generaal (Coen) de Ternatanen genegen was. Niet om het slechten der forten, dit achtte hij van weinig beteekenis, maar wat hun wantrouwen opwekte was dit, dat de Hollanders plan hadden Makian aan den Sultan te onttrekken en tot hun eigen gebied te verklaren, waardoor zij tegen het gesloten verdrag hem van zijne inkomsten en waardigheid zouden berooven. Hij hoopte nog, dat de Generaal misleid was en bij rijper nadenken zoo onberaden niet zijn zou, maar dit kon hij verklaren, dat de Ternatanen liever hun leven zouden opofferen dan dat aan het gezag van hun Sultan afbreuk werd gedaan. Stuling beloofde zijne bezwaren aan Lam over te brengen, die niet nalaten zou, als hij te Batavia kwam, ze den Generaal mede te deelen. Hij verzekerde hem echter dat de Generaal niets tegen de Ternatanen zou "attenteeren", wat met zijne eer en de gemaakte contracten streed. Als Stuling Coen's instructie aan Houtman gekend heeft, wist hij wel dat die "eer" en die "contracten" voor den Generaal weinig beteekenis hadden. 1

De Gouverneur-Generaal was natuurlijk ontevreden, dat Houtman het slechten der forten niet had doorgezet. Toen nu Lam en de overige hoofdbeambten in de Molukken, die thans door anderen vervangen waren, te Batavia kwamen, liet hij hen daarover schriftelijk advies geven. Deze adviezen zijn ons bewaard gebleven. ${ }^{2}$ De groote meerderheid was voor 't behoud van alle forten op Ternate, omdat anders de Spanjaarden er den baas zouden spelen. Ook Sabua, van waar men sagu en hout haalde, zou door den vijand bezet worden, als men die plaats verliet. Zoo lang de Spanjaarden er zijn, zeiden sommigen, zijn die lasten niet te vermijden. Laat men hen eerst verdrijven, dan hebben wij de Ternatanen meer in onze macht. $\mathrm{Nu}$ zouden zij zich, als wij hen tot het uiterste dreven, met onze vijanden tegen ons verbinden. Wat Makian en Motir aanging, de meesten oordeelden dat, indien wij die eilanden aan de Ternatanen ontnamen, ook de Makianners en Motireezen ons zouden ontloopen. Hunne onderlinge veeten toch vergaten zij, wanneer het onderdrukking van Mohammedanen door Christenen gold. Dat dit juist was gezien , bleek ook uit de berichten van Houtman. "Wat ons vroeger door

1 Bouwstoffen, bl. 304-7. Vgl. aldaar bl. 299.

2 Advyzen op de Propositie van den Gouv. Gen. in d. 8 Oct. 1621. 
de kommiezen is diets gemaakt", schreef hij aan Coen, "dat de Makianners gaarne van Ternate los zouden zijn, bevinden wij onwaar te wezen, daar zij ronduit zeggen: indien de Ternatanen vertrekken, zullen wij volgen." Zij vreesden dat Coen met eene armada zou komen om hen tot Christenen te maken. 1

De politiek der Hollanders, die vloten naar de Philippijnen zonden om de Spanjaarden te bestoken en er niet aan dachten hen uit de Molukken te verdrijven, moest de Ternatanen wel bevreemden en achterdocht inboezemen. Zij schroomden nu ook niet van dien toestand partij te trekken en met de Tidoreezen een wapenstilstand te sluiten, wat hun het voordeel gaf dat zij door dezen hun nagelen aan de Spanjaarden konden verkoopen, die ze zonder twijfel beter betaalden dan de Hollanders. Houtman moest dit wel dulden, want, schreef hij aan Coen, "onze zwakheid belet ons uit onze schulpen te kruipen." Het was zoo ver gekomen, dat hij Ali hulp moest vragen om te beletten dat de Spaansche galeien hem voor Malaju kwamen trotseeren. Ali toonde nu dat hij zijn plicht als bondgenoot wilde vervullen. Met zijn vloot van 25 korakora's, die gereed lag voor eene samenkomst met de Tidoreesche om den vrede tusschen de beide Sultans plechtig te sluiten, tastte hij een der Spaansche galeien zoo moedig aan, dat zij in een uur tijds veroverd werd. Van de 330 koppen, waarmede de galei bemand was, werden er 130 gevangen gemaakt, waarbij 40 Spanjaarden, en de overigen gedood.

Houtman liet niet na zijne tevredenheid over de Ternatanen aan Coen te kennen te geven. Hij was er van overtuigd, dat zij de handelingen van Hidajat op de Ambonsche eilanden afkeurden en dat hij meer dan eens was teruggeroepen. Ook Van Speult moest erkennen dat de Sultan van Ternate zijne onderdanen aldaar verboden had om de inlanders die het Hollandsche gezag erkenden "Moorsch te maken " en hen gelast het geschut dat hun geleend was uit te leveren 2. Maar dat Hidajat zich niet aan de orders van den Sultan liet gelegen liggen, was voor Coen bewijs genoeg dat die bevelen slechts gegeven waren om de Hollanders om den tuin te leiden. Ja, als de Ternatanen een vloot uitrusten om hunne onderdanen op de omliggende eilanden tegen de Tidoreezen te beschermen, meent Coen dat zij slechts onderling vijandschap veinzen, "de eenen om ons, de anderen om de Spanjaarden een voordeel af te zien!” Geen wonder dat hij over

1 Houtman aan Coen, 14 Augustus 1621.

2 Houtman aan Coen, in Bouwstoffen bl. 351; Van Speult aan Coen, 9 Sept. 1622. 
Houtman de schouders ophaalde, toen deze het verzoek van Ali steunde om de Spanjaarden, die nu zeer zwak waren, met een goede macht uit de Molukken te verdrijven ${ }^{1}$. Begreep Houtman dan niet dat het niet de Spanjaarden waren, maar de Ternatanen die ons het meest in den weg stonden? 2 Voor het jaar 1622 ten einde was, werd iemand die hem beter verstond dan Houtman, Jaques le Febvre, tot Gouverneur der Molukken benoemd.

Wat de Engelschen betreft, het duurde niet lang of zij begrepen dat hier geen voordeel voor hen te behalen viel. De artikelen van het contract werden door de Hollanders natuurlijk in hun voordeel uitgelegd. Zoo eischten zij dat de Engelschen hun deel in de kosten in contanten opbrachten, terwijl zij zelven de inlanders en soldaten in goederen betaalden. Dit bleek weldra geheel ondoenlijk, daar Fursland en de zijnen te Batavia niet in staat waren hen van geld, zelfs niet tot aanschaffing van het noodigste, te voorzien. Het eenige schip dat zij in de Molukken bezaten moest om die reden naar Batavia worden terug gezonden. Nog geen twee jaren waren verloopen of de laatste Engelsche factor keerde op een Hollandsch schip naar Batavia weder 3.

1 Coen aan Bewindh., 6 Sept., 28 Dec. 1622.

2 Zie ook Coens Advys van 1623 in Kronijk van 't Hist. Gen. IX, bl. 103.

3 Calendar II, No. 1067, 1153; III, No. 47, 101, 102, 106, 137, 370, 434. 


\section{ZESDE HOOFDSTUK.}

Bantam blijft den vrede weigeren. Betrekking der Hollanders tot den Panembahan van Mataram. Zijne veroveringen op Java. Sukadana op Borneo aan zijn gezag onderworpen. Hendrik de Haen door Coen als gezant aan hem afgevaardigd. De Engelschen kunnen aan de voorwaarden van 't accoord met de Hollanders niet voldoen. Vloot van defensie naar de Philippijnen (1620-22), naar de kust van Voor-Indië en Afrika (1621-23). Kruistochten in de zeestraten. Expeditie onder Corn. Reyersz naar China (1622-23). Vergeefsche aanslag op Macao.

In Juli 1621 kwam Coen van zijn tocht naar de Banda-eilanden te Batavia terug. Dank zijne instructies, was in de verhouding tot Bantam geene verandering gekomen. Met tinggangs en jachten had men de Bantammers zelfs het visschen belet, en om de manschappen aan te vuren voor elken levenden Javaan eene premie van 20 , voor het hoofd van elken gedooden 10 realen uitgeloofd. De gevangenen werden gebruikt om aan de vestingwerken van Batavia te arbeiden. Natuurlijk oefenden de Bantammers met hun oorlog̣svloot weerwraak waar zij konden.

Toch was de voorraad peper, die te Bantam lag opgestapeld, voor Hollanders en Engelschen een te groot lokaas om niet nogmaals pogingen tot verzoening te doen. Zoo kwam het dat in September 1621 de Raad van defensie weder twee zijner leden naar Bantam zond met voorstellen van vrede aan den Pangeran. Zij kregen geen gehoor, maar alleen de boodschap dat de Engelschen vrij te Bantam mochten komen. Met hen voerde hij geen oorlog, maar alleen met de Hollanders, en, tenzij dezen Djakatra overgaven, verlangde hij geen vrede. De Chineezen zeiden later dat de gezanten verkeerd hadden gedaan na dit antwoord dadelijk te vertrekken, want de meeste Bantammers verlangden wel degelijk naar vrede. Hoe dit zij, de onderhandelingen zouden toch op de hooge eischen van Coen, die niet alleen het monopolie van den peperhandel, maar ook de betaling der oude schulden van Bantam en Djakatra en bovendien schadevergoeding verlangde, zijn afgestuit 1.

1 Instructie van Coen aan Pt. de Carpentier en Jac. Dedel, 12 Jan. 1621; Coen bij De Jonge, IV, bl. 249, 255; 256; Pt. de Carpentier aan Bewindh., 8 Mrt. 
Er mogen vele Bantammers geweest zijn die den oorlog moede waren, en de armoede, die er heerschte ten gevolge van het stilstaan van den handel, verklaart dit genoegzaam, maar dat de Pangeran van zijn eisch geen afstand wilde doen, bleek opnieuw in 1622, toen van Bantamsche zijde uitzicht op vrede gegeven was en Coen nu op nieuw afgevaardigden zond om met den Pangeran en den Sultan te onderhandelen. Zij moesten 't zelfs doen voorkomen, alsof hij gezind was van Djakatra afstand te doen. Maar alles te vergeefs. De Pangeran doorzag hem en liet hem antwoorden dat hij eerst de vesting maar sloopen en de plaats verlaten moest.

Of, zoo als Coen vermoedde, de Pangeran die onderhandelingen had uitgelokt om zekerheid te verkrijgen of de Hollanders reeds met den vorst van Mataram een verbond tegen Bantam gesloten hadden, is moeielijk uit te maken. Er is geen bewijs dat die pogingen tot vrede van den Pangeran zelven zijn uitgegaan. Gebrek leed men te Bantam niet. De Pangeran had reeds in 1620 voor aanplantingen van rijst en oebi in plaats van peper gezorgd, zoodat de levensmiddelen er goedkoop waren 1 .

Wat den Panembahan van Mataram betreft, met wien Coen sinds 1619 alle betrekkingen had afgebroken, de schade die de Hollanders aan de scheepvaart zijner onderdanen toebrachten, en de steun dien zij den adipati van Surabaja hadden toegezegd, zullen hem tot het inzicht hebben gebracht dat het wenschelijk was hen althans voorloopig te vriend te houden, tot hij zijn plan, de verovering van geheel Java, volvoerd had. In 1619 was ook Tuban in zijn handen gevallen, en nu lag Surabaja het eerst aan de beurt; het was dus wenschelijk dat de Hollanders hem daar niet bemoeielijkten. Door tusschenpersonen liet hij Coen polsen over een gezamenlijken aanslag op Bantam en hem uitzicht geven dat hij de Hollandsche gevangenen - er waren er later nog eenigen in zijn handen gevallen zonder losgeld zou uitleveren, indien hem dit verzocht werd. Intusschen liep het gerucht dat hij van plan was Batavia met 100.000 man aan te tasten, hetgeen de gevangenen niet nalieten aan Coen over te brengen, die hun daarop spottend antwoordde, dat eenige duizenden van 's vorsten onderdanen hem zeer welkom zouden zijn om aan 't fort te helpen arbeiden. Toen in September 1620 Aart

1621 ; Resol. GG. en Raden 24, 27 Sept., 1 Nov. 1621; Coen aan Bewindh., 20 Dee. 1621 ; Calendar II, No. 948, 981, 1172.

1 Coen bij De Jonge, IV, bl. 267, 270-273; Coen aan Bewindh. 31 Juli 1620. ธe Volgr. II. 
Gijsels, van Ambon komende, met drie schepen voor Djapara lag, werd hem door den regent van Kendal vanwege den Panembahan op nieuw te kennen gegeven, dat hij de gevangenen op het eerste verzoek van Coen zou uitleveren. Hetzelfde werd aan de gevangenen zelven gezegd, die zich thans te Tagal bevonden, door den regent van die landstreek. De Generaal had slechts aan den Panembahan zijne verontschuldigingen aan te bieden, met een geschenk bij wijze van eerbetoon, waarmede natuurlijk zijne erkenning als opperheer bedoeld werd. Maar Coen vond zoo 't schijnt te veel baat bij zeęroof. In weerwil van 't protest der Engelschen, die te Djapara vreedzaam handel dreven, liet hij Gijsels daar weder eenige jonken aantasten en berooven. Ook twee jonken van den regent van Kendal, die rijst naar Malaka brachten, werden door de Hollanders buit gemaakt en bij die gelegenheid bleek het dat die regent ook de Portugeezen te vriend wilde houden. Maar dit belette niet dat dezelfde regent ook Batavia van rijst bleef voorzien, eenige gevangenen uitleverde en Coen in Maart 1621 liet verwittigen, dat de Panembahan dit jaar voornemens was zijne plannen tegen Surabaja ten uitvoer te brengen en hem daarom ried het volk en de goederen te Gresik in veiligheid te brengen, hetgeen ook kort daarna geschiedde. Het duurde nog een jaar voor die veldtocht plaats had, maar tot de verovering van Surabaja kwam het ook toen nog niet. Wel werden Gresik en Djaratan weder geplunderd en in brand gestoken. 1

Waarschijnlijk was het de regent van Tagal, die beproefde of hij aan de overgebleven gevangenen nog wat verdienen kon en een losgeld van 5000 realen eischte. Ze werden echter op last van den Panembahan in November 1621 zonder losprijs uitgeleverd 2 , waarop Coen ook een vijftigtal Javanen in vrijheid stelde. Te gelijkertijd liet de regent van Tagal Coen uit naam van den Panembahan aanzeggen, dat de vorst alle vroegere geschillen wilde vergeten en in vriendschap met de Hollanders leven. Coen schreef den Regent dat

1 Zie over 't voorgaande: Coen in Dodts Archief bl. 220; Coen bij De Jonge, IV, bl. 184, 189, 192-93, 202-3, 205, 217, 251, 255, 261; vgl. De Jonge's Inleiding bl. CXLIII-CXLVII; Resol. GG. en Raden 1620; Brieven gewisseld tusschen Coen en de gevangenen B. van Eyndhoven en Corn. van Maseyck, Apr.-Oct. 1620; Coen aan Bewindh. 26 Oct. 1620; M. L. van Deventer, Geschied. der Nederl. op Java, I, bl. 141. De heer Van Deventer heeft te recht opgemerkt dat Coen reeds in 1616 aan Druyff gelast had den Panembahan uitzicht te geven op hulp tegen Bantam. Vgl. mijn Achtste gedeelte blz. 350 .

2 Blijkens een PS. onder Coens brief van 16 Nov. 1621, dat door De Jonge weggelaten is. 
het hem zeer aangenaam was dit te vernemen en zond hem eenige geschenken. Maar het stond nog niet bij hem vast, welke gedragslijn hij tegenover Mataram zou volgen. Hij begreep zeer goed dat het den Panembahan alleen te doen was om niet in zijue veroveringen belemmerd te worden, en achtte het volstrekt niet wenschelijk dat ook Bantam in zijn macht kwam. Voor hij echter een besluit nam, wilde hij eerst het advies van Bewindhebbers afwachten. ${ }^{1}$

Bewindhebbers zagen den toestand in zooals Coen. Den vorst van Mataram te helpen tegen Bantam was ongeraden; men moest "den een tegen den ander laten slijpen en consumeeren". 2 Coen kon dit advies nog niet ontvangen hebben, toen in Juni 1622 de regent van Tagal opnieuw gezanten naar Batavia zond, die zich nader verklaarden over de plannen van den Panembahan. Zijn gebied strekte zich reeds oostelijk uit tot de landstreek Krawang, die aan Bantam behoorde ${ }^{3}$, en nu wilde hij dit gewest, onder voorwendsel dat het aan zijne voorzaten behoord had, heroveren en, liever nog, zich ook van Bantam meester maken. Daarover zou hij gaarne met Coen in persoon onderhandelen of, zoo hij zelf niet bij hem kon komen, dan verzocht hij hem een gezantschap te zenden.

Zonder zich tot iets te verbinden, wilde Coen toch den Panembahan te vriend houden. Nog onlangs had men gezien dat zijne macht, zelfs ter zee, niet gering was te schatten. Reeds een paar jaar was er sprake van ${ }^{4}$, dat hij het rijk van Sukadana aan de westkust van Borneo, dat onder de suprematie stond van den adipati van Surabaja, aan zijn gezag wilde onderwerpen. Om die reden had de Hollandsche factor Jacob de Natelaer de loge te Sukadana laten versterken en volk in dienst genomen. Maar Coen, ontevreden over 't geen hij geldverspilling achtte, liet Natelaer in 1622 door een ander vervangen, het volk afdanken en het geschut inschepen. Tegen "openbaar geweld" moest de Souverein van 't land de Hollanders

1 Coen aan den gouverneur van Tagal, 9 Dec.; Resol. GG. en Raden 16 Dec.; Coen aan Rewindhebbers, 20 Dec. 1621.

2 Bewindh. aan Coen, 24 Oet. 1621.

3 Tjeribon had zijn oppergezag erkend.

4 Misleid door eene onduidelijkheid in 't Discou.rs van S. Bloemaert (in "Begin en Voortgang der O. I. Comp.", achter 't Journaal van Verboeff, bl. 107) heeft de heer Veth (Borneo's Westkust I, bl. 210) gemeend dat de Panembahan reeds in 1610 op een tocht naar Borneo plan zou gehad hebben, doch wat daar van zijne plannen gezegd wordt heeft niet op Borneo maar op 't gebied van Surabaja betrekking. 
beschermen. 1 Indien maar de Souverein van 't land er toe in staat was geweest! Den zesden Mei 1622 verscheen op eens een vloot van 100 prauwen onder aanvoering van den regent van Keudal, Tumenggung Buraksa, voor Sukadana. De Javanen, die de stad omsingelden, hadden veel te lijden van het vuur en de pijlen der belegerden, maar dezen zagen zich al spoedig genoodzaakt de stad te ruimen. De borstweringen werden nu met ladders beklommen en de stad ingenomen. De oude Koningin en eenige honderden personen, meest vrouwen en kinderen, werden gevangen naar Java medegevoerd.

De Hollandsche koopman was met de zijnen bij tijds gevlucht, na zijne kostbaarheden met die van den Engelschen factor begraven te hebben. De laatste werd door het springen van zijn eigen kruid gedood, maar de Hollanders keerden na 't vertrek der Javanen in de stad terug, vonden hun schat gelukkig weder en kwamen daarmede behouden te Batavia 2.

Het gerucht der verovering van Sukadana was in Juni tot Batavia doorgedrongen, maar omtrent het lot der Hollanders was men nog in 't onzekere. Coen besloot nu een jacht naar Kendal te zenden om den regent inlichtingen te verzoeken. Op dit jacht zou zich ook doctor Hendrik de Haen met gevolg inschepen en te Tagal aan land gaan om zich van daar in gezantschap naar Karta, de residentie van den Panembahan te begeven 3. Het journaal van De Haen is ons bewaard gebleven 4. De Hollanders bezochten eerst Tjeribon, om aan de vorsten van dat gewest, die nog eene zekere onafhankelijkheid bezaten, geschenken te overhandigen, voeren toen naar Tagal en reisden van van daar, door den regent van die landstreek begeleid, naar Karta. De Panembahan, dien De Haen beschrịft als een man van dertig jaar, "fraai van gestalte, rondom zich ziende als een leeuw", dankte hem voor de medegebrachte geschenken en gaf hem te verstaan dat de Generaal niet moest aarzelen met Bantam aan te tasten. Bezat hij daartoe geen macht genoeg, dan zou hij hem wel hulp zenden. De Haen antwoordde, dat de Generaal slechts een defensieven oorlog tegen

1 Van Dijk, Neerlands vroegste betrekk. met Borneo, bl. 172.

2 Coen bij De Jonge, bl. 266; Journaal van De Haen, aldaar p. 219, 293, 294, 300 , 307, 310, 315; Van Dijk, a. w. bl. 172-76, 184; Calendar III, No. 111, 143 (p. 63), 145.

3 Resol. GG. en Raden, 21 Juni 1622.

4 Bij De Jonge, IV, 284-321. De Haen was als "opperbarbier" of chirurg uit Nederland gekomen. 
Bantam voerde en nooit van plan was geweest die stad aan te tasten; anders had hij dit al voor acht of tien jaren kunnen doen. Vreesde de Generaal dan misschien dat de Bantammers de peperranken zouden vernielen? bracht de vorst in 't midden. Dan wist hij daar wel raad op; hij zou ze door zijn volk opnieuw laten planten. Ook mocht de Generaal, als hij rijst of andere eetbare waren noodig had, die uit zijne havens laten halen. Wist de Generaal wel dat de Sultan van Bantam den adipati van Surabaja (dien hij als een opstandeling beschouwde) hulp had willen verleenen tegen hem? Zoodra hij Surabaja had veroverd, zou hij zijne wapenen tegen Bantam keeren. Voor het geschut van den Sultan vreesde hij niet, indien de Hollandsche schepen maar voor de stad lagen. Hierop nam hij zijn kris, deed die in een gouden scheede en verzocht De Haen die uit zijn naam aan Coen te overhandigen. De waarde van het geschenk kwam niet in vergelijking bij hetgeen deze voor hem had medegebracht, maar het was het hoogste wat een Javaan iemand geven kon. Ook moest hij den Generaal verzekeren dat hij hem te Djakatra vrij en vreedzaam zou laten wonen en hem geen overlast aandoen.

Met deze boodschap keerde De Haen naar Batavia terug. Wat verstandige Javanen van die vriendschap van den Panambahan dachten, bleek hem op zijn terugreis te Tagal. De broeder van den regent liet zich hier in dronkenschap ontvallen: Als de Panembahan Bantam maar eerst in zijn bezit heeft, zal hij Batavia ook wel in zijn macht zoeken te krijgen. Daarom ried hij de bolwerken zoo sterk te maken dat hij er niets kon uitrichten. De uitkomst zou leeren dat dit een verstandige raad was. Vooreerst bleef de aanslag tegen Bantam nog rusten, daar het den Panembahan in 1622 nog niet gelukt was Surabaja te bemachtigen. Coens opvolger zou er meer van vernemen.

Van de Engelschen was in deze onderhandelingen met den vorst van Mataram geen sprake geweest. Coen weigerde hun ronduit aan 't gezantschap deel te nemen. Hun toestand te Batavia werd hoe langer hoe onhoudbaarder. "Het is een leven van slavernij dat wij moede zijn", schreven zij aan hunne principalen. En geen wonder: zij werden niet in staat gesteld aan de voorwaarden van 't contract te voldoen. De weinige schepen, die hun gezonden werden, waren slecht voorzien. Het ontbrak hun aan alles: geld, levensmiddelen, zelfs inkt en papier! 1 Aan de blokkade van Bantam moesten zij

1 Calendar III, No. 43. Voeg daarbij dat het volk veel hooger eischen deed dan de Hollanders. "The English", schreef hun eigen President, "murmur at three meals 
zich reeds in Augustus 1621 onttrekken. Een jaar later waren zij genoodzaakt hunne schepen uit de Philippijnen terug te roepen, omdat zij die niet meer konden onderhouden, en om dezelfde reden moesten de factorijen in de Molukken en de Banda-eilanden worden opgeheven.

Coen juichte, want nu achtte hij zich tegenover de Engelschen evenzeer ontheven van 't nakomen zijner verplichtingen. Bewindhebbers hadden naar zijn raad geluisterd. Om ons recht te kunnen handhaven, had hij hun geschreven, hebben wij meer macht noodig. "Er is ter wereld niets dat de menschen beter recht verleend dan macht en geweld bij 't recht gevoegd" 1 Die macht werd hem verleend. "Majores hebben dit jaar", schreef hij aan Van Speult den 28 Februari 1620 , "16 treffelijke schepen gezonden, waarvan de uitrusting 44 tonnen gouds beloopt/" 2 . In 1620 werden 20 , in 1621 13 schepen uitgerust, met een flink kapitaal. In September 1622 telde de Hollandsche vloot in Indie 83 bodems, de Engelsche slechts 28, die zij nog niet van het noodige konden voorzien. Dat zij in deze omstandigheden in den Raad van defensie weinig hadden in te brengen 3 en dat Coen zijn eigen weg ging, is te begrijpen. Bewindhebbers mochten hem al gelasten geen "hostile proceduren" tegen de Engelschen voor te nemen en hem berispen, dat hij hen door zijne hardheid te veel verbitterde en niet genoeg in het oog hield dat hetgeen hij in Indie deed zijne meesters in Europa moesten kunnen verantwoorden, 4 Coen was ten volle overtuigd dat hij niet anders handelen kon. "'T kan wel zijn, antwoordde hij, dat wij ons tegen de Engelschen of Franschen in eenig opzicht onbedacht misgrepen hebben, willens is 't niet geschied. Maar hoe is het mogelijk

of fresh meat a week. The Dutch have been content with rice alone for a year together, but if the English were put on such allowance they would turn rogues (as many of them are never better) to betray your ships before they would endure it."

1 Coen aan Bewindh., 11 Mei 1620.

2 Daaronder "5 geweldighe oorlogschepen by 't gemeyne landt gebouwt" Bewindh. aan Coen, 10 Sept. 1619. - Den 12 Dec. 1620 schreven zij echter aan Coen: "Het is er zoo ver af dat wij groote assistentie zouden mogen bekomen van de Staten Generaal dat veeleer remonstrantien aan H. Hoog Mog. worden vertoont bij treffelijke collegien, dat de O. I. Comp. het gemeene land behoort te assisteeren in dezen bezwaarlijken tijd."

3 Calendar, III, No. 140.

4 "Bedenkt dat wij kooplieden zijn, dat veel hoofden veel zinnen maken, dat wij met onze naburige Europeesche natien hier zoo moeten leven dat wij met hen niet geheel overhoop geraken, en meenende de Indische wereld te conquesteeren ons klein gedeelte in de Nederlandsche verliezen." Bewindh. aan Coen, 14_April 1622. 
dat wij er ons voor zouden kunnen wachten de Engelschen te kwetsen, die zich niet schamen actie te maken op landen die aan de Nederlanders zoo veel goed eu bloed gekost hebben en waarop zij niet in 't minste met recht kunnen pretendeeren 1 Men ziet, dit was altijd Coens uitgangspunt gebleven. Het accoord van 1619 had daaraan niets veranderd, en de omstandigheden waren hem gunstig geweest om dat accoord tot een doode letter te maken.

Reeds vóór het accoord hem ter oore kwam, had zijn plan tot uitbreiding van den handel vastgestaan ${ }^{2}$, en in weerwil van de teleurstelling daartoe met de Engelschen te moeten samenwerken, die hem zelfs deed besluiten zijn ontslag te vragen ${ }^{3}$, had hij door de hulp van Bewindhebbers aangemoedigd met vaste hand gearbeid om dat plan ten uitvoer te brengen. Den handel van Oost-Azië zoo veel mogelijk aan de Spanjaarden en Portugeezen te ontrukken en naar Nederland te leiden, was van den beginne het streven geweest der Compagnie; maar er was een man noodig met den ondernemingsgeest en het organiseerend talent van een Coen om op het goede oogenblik maatregelen te treffen en zich niet door teleurstellingen te laten ontmoedigen. De middelen, die men aanwendde om zijn doel te bereiken, kwamen hoofdzakelijk neer op buitvaart of zeeroof, hoe men 't noemen wil. Maar het eigenbelang liep hier gelukkig samen met vernietiging der macht van den erfvijand: Spanje, en hieraan had de Compagnie den grooten steun te danken, dien zij van de Regeering ondervond.

Volgens het tiende artikel van het contract tusschen Hollanders en Engelschen waren twintig oorlogschepen, tien van elke natie, bestemd voor de zoogenaamde defensie, waarover de Raad van defensie te beschikken had. Wij zagen reeds ${ }^{4}$, dat aanstonds na de vereeniging op voorstel van Coen besloten werd een tiental dier schepen naar de Philippijnen te zenden om den handel der Chineezen op Manila te beletten. Den 13 Mei 1620 waren drie schepen onder bevel van Bartholomeus Spilberghen door Coen naar Cabo del Espiritu Santo, den noordoosthoek van Samar, vooruitgezonden om de zilverschepen die van Acapulco naar Manila voeren aan te tasten.

1 Coen aan Bewindh., 20 Juni 1623.

2 Zie zijn brief aan Bewindh. bij De Jonge, IV, bl. 199-200.

3 Den 11- Mei 1620. De Jonge IV, bl. 206. Hierop beloofden Bewindh. hem verhooging van gage indien hij nog 3 a 4 jaar zijn ambt bleef bekleeden (Bewindh. aan Coen, 4 Maart 1621). Vgl. ook De Jonge, IV, bl. 259 en 283.

4 Hiervoor bl. 250 
Den 26 Juni kregen zij drie Spaansche schepen in 't gezicht. De commandant, Fernando de Ayala, was er niet op verdacht hier vijanden te vinden en voer in goed vertrouwen naar hen toe, maar de volle laag uit de Hollandsche schepen deed hem zijn lichtvaardigheid berouwen. Hij onttrok zich echter niet aan 't gevecht, voor zijne schepen zoodanig geteisterd waren dat hij aan hun behoud moest denken. Tot zijn geluk kwam een storm hem te hulp, die den vijand belette hem te vervolgen. De Spaansche schepen konden nu hun schat bergen, hoewel het zilverschip moest verlaten worden; maar van de Hollandsche ging dat van Spilberghen in den storm te gronde. De beide anderen kwamen te Firando in behouden haven. De Gouverneur der Philippijnen, Don Alonzo Fajardo, zorgde nu dat voortaan de schepen, die tusschen Manila en Acapulco voeren, telkens een. verschillenden weg volgden, waardoor zij langen tijd de Hollandsche kruisers wisten te ontgaan. 1

In 't laatst van Mei en 't begin van Juni 1620 voer de vloot naar Manila bestemd langs verschillende wegen naar Firando om zich daar te vereenigen. De Engelsche admiraal Martin Pring had geweigerd het opperbevel te aanvaarden, dat nu aan kapitein Robert Adams werd toevertrouwd. Willem Jansz (van Amsterdam) werd tot vice-admiraal benoemd. Zij hadden in last de Japansche jonken niet te beschadigen, ook geen Chineesche op vrije plaatsen varende, en de Chineezen van de veroverde jonken zooveel mogelijk mede te voeren om in den Archipel als kolonisten dienst te doen. 2

Den 13 Januari 1621 zeilde de vloot van Firando naar Manila. De Spanjaarden waren gewaarschuwd en hunne schepen hadden zich in de baai van Cavite zoo goed verschanst, dat de vijand er zelfs geen branders op af kon zenden zonder dat deze gevaar liepen in hunne handen te vallen. Men besloot dus aan de kust op de aankomende jonken te kruisen. Maar ook de Chineezen bleken van hun komst onderricht en hadden hunne beste jonken te Chincheu opgehouden. Slechts vijf van deze vaartuigen vielen de kapers in handen, en op 't laatst van Juni werd het weder zoo onstuimig, dat men besloot naar Firando terug te keeren. Kort daarna liepen drie rijk geladen fregatten van Macao en de zilverschepen van Amerika behouden de baai van Manila binnen 3 .

1 Juan de la Coneepcion, IV, p. 480-86; Coen aan Bewindh. 6 Mei 1621.

2 Instructie in d. 13 Juni; Calendar II, No. 857. Vgl. 883.

3 Coen aan Bewindh., 20 Dec. 1621; Jacq. le Febrre aan dez., uit Firando 14 Oct. 1621; Calendar II, No. 927, 940, 1112. - Jacq. le Febvre was tot 
Op dezen tocht was hèt gebrek aan tucht op de Engelsche schepen overtuigend gebleken. Het volk, dat op koopvaardij gehuurd was, morde dat het tot den oorlog gebruikt werd, en de kapiteins konden of wilden niet beletten, dat het zich van 't grootste deel van den buit meester maakte, zoodat men dit op de Hollandsche schepen ook wel moest toestaan. Maar ook tusschen Engelschen en Hollanders onderling was de verhouding slecht, en dit kon wel niet anders omdat zij zoolang vijandig tegen elkander hadden overgestaan 1.

Voor dat de vloot te Firando was teruggekomen, had de Raad van defensie te Djakatra besloten dat zij zich daar van het noodige zou voorzien en dan den kruistocht hervatten. Vier schepen, een Engelsch en drie Hollandsche, werden haar ter versterking gezonden 2.

Hoeveel in dezen tijd de handel der Spanjaarden en Portugeezen met China en Japan nog beteekende, leeren wij uit de berichten die Coen aan Bewindhebbers zond 3. Een der retourschepen van Manila naar Mexico, verhaalt hij, was aan de kust van Mindoro vergaan. Men berekende het verlies op 2 à 3 millioen realen of 5 millioen guldens. Die van Macao zenden jaarlijks een kapitaal van 4 à 500.000 taels in kleine vaartuigen naar Japan en zouden dit jaar wel het dubbele of 3 millioen guldens in retour bekomen. Niet minder hadden zij dit jaar naar Manila gezonden. Van Macao naar Malaka en Goa was volgens Coens berekening in 1621 voor 2 à 3 millioen vervoerd, en hij meent dat de vijand in 't geheel wel 50 millioen alleen aan kapitaal in Indië gebruikt. En nu denken Bewindhebbers al heel wat te doen als zij 5 à 600.000 realen jaarlijks zenden, maar 't is een boon in een brouwketel.

Den 3 December 1621 begaf de vloot van defensie zich weder van Firando naar de baai van Manila. Ditmaal had Willem Jansz het opperbevel. De Spaansche vloot, die uit 5 of 6 groote en eenige kleine schepen bestond, was weder te Cavite in veiligheid gebracht.

"opperhoofd" op een der schepen (de Trouwe) benoemd. Resol. GG. en Raden 11 Juni 1620.

1 Coen als boven; Calendar II, No. 1105, 1110, 1112, 1172; "Rapport gedaen by verscheyden persoonen" (1622) in Kronijk Hist. Gen. 1871, bl. 321-23.

2 Resol. Raad van defensie, 30 Juni 1621.

${ }^{3}$ Coen aan Bewindh., 21 Januari 1622. In denzelfden brief verhaalt Coen dat in brieven van Juli-September 1621 van de R Audiencia te Manila ann den Koning van Spanje zeer geklaagd werd over den gouverneur, D. Alonzo Fajardo, en een nieuwe gouverneur verzocht, daar hij in 3 jaar 3 millioen onnut zou verspild hebben, zonder iets tegen den vijand uit te richten, en 1 millioen voor zijn particulier naar Mexico gezonden. 
Waarschijnlijk was zij slecht voor den oorlog uitgerust. Ook vernam men dat te Manila groote schaarste heerschte en dat de Spanjaarden een opstand van de inlanders hadden te bedwingen ${ }^{1}$. Van December tot Mei hield een deel der vloot de baai geblokkeerd. terwijl de andere schepen op de ankomende jonken kruisten. De vangst was beter dan de vorige maal en vergoedde rijkelijk de kosten, maar aan vele jonken gelukte het toch ergens aan de kust van Luçon binnen te loopen. In Mei werden 3 schepen naar Macao gezonden om daar te kruisen en veroverden een fregat met zijde. In Juli was de geheele vloot te Firando terug. Ook nu weder was de groote buit hun ontsnapt. Vier schepen uit Mexico, voorzien van volk, geschut en zilver, waren benoorden Luçon omgeloopen en bereikten behouden de haven van Pangasinan. De beide bodems, die Houtman uit de Molukken naar de noordkust van Samar had gezonden, wachtten ze daar te vergeefs en waren zoo lek geworden dat men ze te Firando moest sloopen ${ }^{2}$.

Hoewel de orde op dezen tocht beter gehandhaafd werd dan op den vorigen, zouden toch deze gezamenlijke expedities niet hervat worden. Aan de Engelschen ontbraken de middelen. Zij zonden dus aan Adams bevel met zijne schepen terug te keeren. Ook Willem Jansz. had reeds van Coen last ontvangen om zich op behendige wijze van de Engelschen af te maken, daar hij wenschte dat de commandeur zich met zijne schepen naar de kust van China zou begeven om zich te vereenigen met de vloot, die in dit jaar van Batavia daarheen werd gezonden. Willem Jansz. wilde aan dien last voldoen, maar zijne schepen werden door storm uiteengedreven; en de meesten kwamen na elkander te Batavia aan ${ }^{3}$.

De tweede helft der vloot van defensie was voor een ander doel bestemd. Zij moest de vaart tusschen Voor-Indië en Portugal zoo veel mogelijk trachten te beletten. Uit Nederland werden daartoe reeds in 't begin van 1620 vier schepen rechstreeks naar de Kust

1 Coen schrijft (aan Bewindh. 6 Sept. 1622) dat de bewoners van Cagayan en Zambales (op Luçon) waren opgestaan. Juan de la Concepcion vermeldt alleen een opstand op Bohol en Leyte.

2 Coen aen Bewindh. 6 Sept. 1622; 20 Juni 1623; Calendar II, No. 1095; III, No. 43, 70, 145, 146, 163, 164, 261 en pag. 109 ond.

3 Coen aan Willem Jansz 3 Maart 1622; Coen aan Bewindh. 20 Juni 1623; Calendar III, No. 143. - Zie ook over deze tochten: P. A. Leupe, Willem Jansz van Amsterdam enz. in deze Bijdragen, 3e Volgreeks, dl. VII. 
van Malabar afgezonden; waar zij zich met de Engelsche schepen, die er zich reeds bevonden, moesten vereenigen. Bewindhebbers drongen er bij Coen op aan, dat hij er ook van Batavia zooveel schepen als hij missen kon zou heenzenden, al waren ook de Engelschen niet in staat daaraan deel te nemen. Hoe hoog noodig dit is, schreven zij, kunt gij daaraan zien, dat de Portugeezen zelven hun peper uit Portugal herwaarts gezonden en onder den prijs der Compagnie verkocht hebben. Ja, Bewindhebbers achtten dit "het eenige middel om de waren hier te lande op prijs te brengen." 1

Het duurde tot October 1621 voor men te Batavia voor die expeditie genoegzaam was uitgerust. Eene vloot van elf schepen, zeven Hollandsche en vier Engelsche, begaf zich toen onder zeil naar de kust van Voor-Indië. De raad van Indië Jacob Dedel was tot admiraal, de commandeur Humphrey Fitz-Herbert tot vice-admiraal aangesteld. Het hoofddoel was buitmaken, maar men zou ook trachten aan de kust van Malabar "een vasten voet van peperhandel te vestigen" en het zou de Hollander's vergund zijn zooveel inlanders op te pakken als zij konden, vrijen zoowel als slaven, om Batavia en Banda te koloniseeren 2. Het ligt niet op mijn weg over dezen tocht in bizonderheden te treden. Uit de berichten blijkt, dat de Engelschen Dedel voor onbekwaam hielden en aan zijn gebrekkig beleid het geringe gevolg der expeditie toescheven. Zeker is het dat, toen men den 23 Juli 1622 bezuiden Mozambique de Portugeesche schepen uit Lissabon komende aantrof, 3 karakken en een galjoen, Dedel slechts twee schepen bij zich had en Fitz-Herbert drie ${ }^{3}$. $\mathrm{Na}$ een hevig gevecht werd een der karakken geënterd, maar een groot deel der bemanning wist zich te redden en de buit was gering. De beide andere galjoenen, met den nieuw-benoemden gouverneur van Indië Francisco da Gama, graaf van Vidigeyra aan boord, ontkwamen en strandden aan de kust van Mozambique, maar men kon het geschut en de kostbaarste lading redden. De schepen werden toen in brand gestoken, opdat ze den vijand niet in handen zouden vallen ${ }^{4}$.

1 Bewindhebbers aan Coen, 13 Mei, 12 December 1620, 10 December 1622.

2 Instructie aan Jac. Dedel, 11 Oct. 1621. Vgl. Calendar, II, No. 1108.

3 Dedel had er waarschijnlijk te Surate achtergelaten en 2 naar Mocha gezonden. Hij zal meer belang gesteld hebben in den handel dan in de buitvaart. In October 1620 was te Surate Pieter van den Broecke directeur van den handel geworden. Ook te Mocha was destijds een Hollandsche factorij.

4 Faria y Sousa, Asia Portuguesa III, p, 382; Ign. da Costa Quintella, Annaes da marinha Portuguesa II, p. 207 ; Calendar II, No. 9, 34, 264 (p. 110), 364 (p. 193), Coen aan Bewindh. 6 Sept. 1622, 7 Jan., 20 Juni 1623. 
Dedel en Fitz-Herbert keerden naar Surate terug en voeren in December 1622 naar Goa om die stad te blokkeeren. Maar Gama was toen reeds met zijn schat in behouden haven. Het eenige wat men met de blokkade bereikte, was dat in 1623 geen retourvloot naar Portugal kon uitzeilen. In den zomer van dat jaar kwamen de schepen te Batavia weder. De Engelschen beklaagden zich zeer over Dedel en weigerden thans ook deze expeditie gezamenlijk te hervatten 1.

In September 1621, kort voordat de tweede vloot van defensie in zee stak, had Coen ook eenige schepen en jachten uitgezonden om in de zeestraten van Sabang en Singapura te kruisen op de schepen die van Malaka oostwaarts voeren. Bevelhebber over dat eskader was Jan van Meldert. Enkele Macaovaarders werden door hem buitgemaakt en eenige jonken te Malaka verbrand. Coen klaagde echter dat hij zijne bevelen slecht had opgevolgd. Met nog geringer uitslag werd deze kruistocht in 1622 voortgezet. De Portugeezen waren toen blijkbaar op hun hoede ${ }^{2}$.

Ook aan de vrije burgers van Batavia had de Gouverneur-Generaal in 1621 verlof gegeven tot buitvaart op de jonken die zich naar Malaka begaven. De instructie die hij hun gaf schijnt zeer onduidelijk geweest te zijn, 't geen te onvoorzichtiger was, omdat hij wist met welk volk hij te doen had 3. Zij ontzagen zich dan ook niet aan de noordkust van Sumatra vaartuigen te veroveren die aan bondgenooten der Hollanders toebehoorden, en 't volk eenvoudig over boord te werpen. Van den Sultan van Djohor, van Djambi, Indragiri, Palembang kwamen hevige klachten over die schending der contracten. Coen liet eenigen der overtreders ophangen, maar daar hij zelf erkende: "het schijnt dat zij mijne redenen anders geduid of niet wel begrepen hebben", was het niet te verwonderen dat sommigen hem verweten "al zijn fouten op des gemeenen mans hals te schuiven en hen dan van kant te helpen" 4 .

1 Calendar III, No. 266 en p. 200, 204 ; Pt. de Carpentier aan Bewindh. 24 Febr. , 25 Dec. 1623.

2 Resol. GG. en Raden 23, 31 Augustus 1621; Coen aan Bewindh. 20 Dec. 1621,20 Juni 1623.

3 "Tot noch toe siet men hier weynich die niet met de vryheyt in beesten veranderen." Coen aan Bewindh. 26 Mrt. 1622. - "Their burghers, being such of their own nation as are married with the scum sent out of Holland or with the Indians, prove the worst neighbours merchants can desire." Calendar III, No. 392.

4 Coen aan Adr. van der Dussen te Djambi, 5 November 1621, Dez. aan Bewindh. 16 Nov. 1621, 26 Mrt. 1622; Rapport van personen komende uit O. Indië (1622) in Kronijk Hist. Gen. 1871, bl. 330 , 331. 
In April 1622 was Coen in staat een stouter plan ten uitvoer te brengen. Het gold ditmaal een tocht naar het Hemelsche rijk, ten einde de Chineezen te dwingen voortaan te Batavia te komen, want tot nog toe hadden slechts een paar hunner handelsvaartuigen de reis zoover uitgestrekt. Die reis toch was veel omslachtiger en onzekerder dan die naar Manila, waar de Spanjaarden, door den aanvoer van zilver uit Amerika, hen altijd van dat gezochte ruilmiddel hadden kunnen voorzien. Bewindhebbers hadden reeds in 1620 aan Coen hun wensch te kennen gegeven, dat hij een bekwame plaats zou opzoeken om voor station van den Chineeschen handel te dienen, en hem medegedeeld dat hun daartoe, "zoo door berichten van de Portugeezen als door anderen die in hun dienst geweest waren, Lequeo pequeno was aanbevolen" ${ }^{1}$. Zij hadden daarmede op 't oog niet een der Liu-kiu eilanden maar het groote eiland Formosa ${ }^{2}$. Een jaar later ${ }^{3}$ gaven zij den Gouverneur-Generaal in bedenking om de haven van Chincheo en de rivier van Canton te bezetten. Niet zonder invloed op diens besluit was een Spaansch tractaat dat de Hollanders in 1621 buitmaakten in een vaartuig dat zich van Macao naar Malaka begaf 4. De schrijver, een Spanjaard te Manila, betoogde daarin dat het voor den handel van China op de Philippijnen van belang zou zijn op Formosa een fort te bouwen. Die handel toch liep groot gevaar, daar de Chineezen door de zware verliezen die zij geleden hadden van de vaart werden afgeschrikt. Daarbij kwamen de binnenlandsche onlusten in China en de oorlog tegen de Tartaren (de Mantschu), waartoe de soldaten, die anders de kusten bewaakten, werden opgeroepen, zoodat Japansche en Chineesche zeeroovers de kusten onveilig maakten en vele handelaars hun kapitaal niet meer durfden wagen. Maar de voornaamste reden waarom men niet moest talmen met het bouwen van een fort, was

${ }^{1}$ Bewindh. aan Gouv. Gen. en Raden, 24 Mrt., 9 Sept. 1620.

${ }^{2}$ Dit blijkt duidelijk uit de brieven van Coen, die spreekt van "Lequeo pequeno of Formosa". Dat de Chineezen ook Formosa tot de Liu-kiu oilanden rekenden is bekend. Den naam Taywan schijnt het eiland yan de havenplaats ontvangen te hebben. Richard Cocks, de Engelsche factor te Firando, schrijft, dat de Chineezen het eiland Taccasanga noemen (Calendar, III, No. 323).

3 Bewindh. aan Gouv. Gen. en Raden 4 Maart 1621.

4 Het bevindt zich op 't R. A. met het Purtugeesche opschrift: "Tratado Espanhol aserca de fazer forte em ilha Fermosa." Vgl. Coen's brief aan Bewind. van 26 Mrt. 1622, en het "Cort verhael vant proffijt..... dat de heeren bewindhebberen ... in Japan souden mogen genieten bij sooverre UEd. de Chinese handel bequamen" (1622) in Kronijk Hist. Gen. 1853, bl. 58 vv. 
deze, dat de Hollanders hetzelfde voornemen hadden en slechts op verlof uit Holland wachtten om het ten uitvoer te brengen. Waren zij eenmaal op Formosa gevestigd, dan zouden zij niet alleen de vaart op Manila kunnen beletten, maar ook de handel met Japan zou groot gevaar loopen zich naar Formosa te verplaatsen. De Japanners toch hadden reeds lang gewenscht en somtijds beproefd zich op Formosa te vestigen en nu zouden zij, onder bescherming der Hollandsche schepen, hier zelven met de Chineezen komen handelen; de vaart van Macao op Japan zou daardoor te niet gaan, en de Keizer van Japan, ziende hoeveel dienst de Hollanders zijne onderdanen bewezen, zou hun weerkeerig genoegen willen doen en de vaart op Manila verbieden.

Vervolgens deed de Spaansche schrijver de voordeelen eener vestiging op Formosa uitkomen boven die te Macao of elders aan de Chineesche kust, waar de Europeërs voortdurend aan den willekeur der Chineesche overheden zijn blootgesteld, en de schade die daardoor aan den vijand kon worden toegebracht. Hij had van den overste der Chineezen te Manila 1 vernomen, dat er een haven was aan de westkust van het eiland en dat de Hollanders daar het vorige jaar met 3 schepen en 30 Japaansche vaartuigen geweest waren en de Chineezen er in kleine vaartuigen veel waren hadden heengebracht 2 .

Omtrent die haven was Coen beter ingelicht dan de schrijver van 't Spaansche tractaat; de Hollandsche schepen hadden daar bij 't inkomen van de reede niet meer dan 10 of 12 voet water gevonden. Hij achtte 't dus verkieselijker dat men zich op de Pescadores, een groep van kale eilanden tussehen Formosa en China, vestigde, waar een zeer goede reede was, en de Chineezen zoo hij meende (maar daarin vergiste hij zich) geen rechtsgebied hadden. Na lang beraad werd in 1622 door den Raad van Indië tot die vestiging besloten, maar eerst zou men onderzoeken of Macao zoo slecht versterkt was als de berichten luidden, en in dat geval die plaats trachten te

1 "Governador de los Sangleios."

9 Ik heb alle Holl. brieven uit Japan niet geheel gelezen en kan dus de juistheid van dit bericht niet bevestigen. In de Instructie van Corn. Reyersz wordt gezegd: "Ons is daer (op Formosa) geen andere plaats bekent dan l'angesan, gelegen op $23^{\circ}$ alwaar de onze van 't verloren schip de Engel geweest zijn, met niet meer dan 12 voet water op de bank van de inkomst." Dit zal in of na 1619 geschied zijn, want de "Engel" behoorde nog tot de vloot waarmede Coen zich van Ambon naar Djakatra begaf. Maar misschien was het een andere "Engel". 
veroveren. Twaalf zeilen werden voor de expeditie bestemd, bemand met 1000 Nederlanders en 150 slaven. Het opperbevel werd opgedragen aan Cornelis Reyersz, in December 1620 als vice-commandeur eener vloot in Indië gekomen. De ervaren opperkoopman Cornelis van Nijenrode, die als factor in Siam Cochinchina had bezocht, zou hem ter zijde staan. De welbekende schipper Willem Ysbrantsz Bontekoe nam deel aan den tocht en heeft dien in zijn journaal beschreven.

De instructie, door Coen aan Reyersz en zijn Raad gegeven, maakt thans een komischen indruk. Zoo weinig wist Coen van de ontzachlijke hulpbronnen van het Hemelsche rijk, dat hij zich verbeeldde met duizend man de Chineezen te kunnen dwingen hem "de bekwaamste plaats omtrent hun kust" af te staan! Indien zij uitvluchten zochten, moest Reyersz hun den oorlog verklaren en alle mogelijke afbreuk doen. Dan kon hij veel volk oplichten "om Batavia, Ambon en Banda te peupleeren", wat alleen de kosten van de reis reeds zou vergoeden. 1 Ook moest hij niet toestaan dat de Chineesche jonken elders heenvoeren dan naar Batavia. ${ }^{2}$

In 't laatst van Mei kwam de Hollandsche vloot aan de kust van China, waar zich nog zes schepen van de vloot van defensie bij haar vervoegden, vier Hollandsche onder Jacques le Febvre, en twee Engelsche onder Charles Clevinger. Clevinger wilde deelnemen aan de expeditie, maar dit werd door Reyersz afgeslagen. Hij schijnt toch een poos hulp verleend te hebben.

Reyersz bevond dat Macao beter versterkt en bezet was dan men verwacht had, maar achtte het toch doenlijk zich van die Portugeesche eilandstad meester te maken. Na haar een paar dagen beschoten te hebben, deed men den 24 Juni eene landing met 600 man in de baai van Casilhas aan de oostzijde van 't eiland. Eene batterij, door de Portugeezen bij de landingsplaats opgeworpen, werd veroverd en nu trok men op de stad aan. Op een heuvel aan dien kant lag het fort S. Paulo of do Monte, waaruit de Portugeezen nu de aanvallers beschoten. Ook werden de laatsten door het springen van eenige vaten kruid gedwongen op nieuwen aanvoer uit de schepen te wachten. De Portugeezen, door Japansche overloopers hiervan

1 Willem Jansz, zeide hij, had dit niet begrepen, en gedacht dat buit de hoofdzaak was, maar ik vermoed dat die Commandeur er weinig zin in had rijn schepen met Chineezen op te vullen. De Engelschan legden hem ten laste dat hij de Chineezen uit de buitgemaakte jonken over boord liet werpen.

2 Instructie van Corn. Reyersz en Raad in d. 4 April 1622. 
onderricht, deden hierop eenen uitval en sloegen de aanvallers op de vlucht. De achterhoede, die aan 't strand bij de booten wachtte, de anderen ziende aankomen, zocht zich het eerst te redden, zoodat nog vele manschappen bij het inschepen gedood werden. De Hollanders telden 130 dooden en evenveel gekwetsten. Het verlies der Portugeezen was onbeteekenend. Reyersz had bij de landing een schot in den buik gekregen en daardoor de leiding aan anderen moeten overlaten 1 .

De Chineezen hadden tot nu toe allerlei ververschingen aan boord van de Hollandsche schepen gebracht, maar na den aanslag op Macao werd hun dit door de Overheid ten strengste verboden. Aan de Portugeezen daarentegen werd oogluikend toegestaan dat zij Macao beter versterkten. De Gouverneur van Canton zou zelfs last gekregen hebben hen in nood bij te staan ${ }^{2}$. Reyersz begaf zich nu met de vloot naar de Pescadores. Den 11 Juli kwam hij voor Pehu (Pung hu), het grootste dier eilanden, dat een goede baai bezit. Er lagen 10 Chineesche oorlogsjonken en 150 visschersbooten, die allen bij hun komst vertrokken. Pehu was vlak en boomloos, daar de scherpe Noordewind den plantengroei belette. Van hier uit deed Reyersz een onderzoekingstocht langs de kusten van Formosa en naar de omliggende eilanden, maar vond geen bekwame haven. Van de beste, Taiwan aan Formosa's westkust, had de ingang bij hoog water slechts 15 of 16 voet

1 Corn. Reyersz aan Coen, 10 Sept. 1622; Coen aan Bewindh. 20 Juni 1623; Journaal van W. Yz. Bontekoe (Hoorn 1648) bl. 29; Calendar III, bl. 193; Faria y Sousa, Asia Portuguesa, III, 364-65; Maravigliosa e stupenda vittoria ottenuta dalli Portoghesi contra gl'Heretici Olandesi nelle Indie Orientali, cavata dalle lettere venute per via delle Filippine e da una relatione stampata in Lisbona nel mese di Guigno 1623. In Milano, per Pandolfo Malatesta $1623\left(8 \mathrm{pp}\right.$. in $\left.8^{\circ}\right)$. In dit geschrift wordt verhaald dat Macao slecht bezet was, daar de Keizer van China op raad van den Opperbevelhebber van zijn leger tegen de Mantschu (een Christen met name D. Paolo) de Portugeezen van Macao met hun geschut te hulp had geroepen (??) Dit zou aan de Hollanders ter oore zijn gekomen. - In een brief van Bontekoe aan Coen van 4 Jan. 1623 wordt gezegd: "Souden soe veel volck niet verloren hebben hadde onse coopman Boshart vast gestaen met den coopman van de Trou. Die waeren om leech op den strand geordonneert, off het quam dat ons volck mosten die vlucht neemen dat sy den vyant wat stuenen souden, opdat t'ander volck mochten in die boot coemen. Doch sy hilden geen stal, waeren van deerste in die boots, ende Boshart kroop onder die dochten van die boot, seggent ons volek, waer over Jan Haegel hem noemen Capeteyn Dofft", etc. - Zie ook A. Ljungstedt, An historical sketch of the Portuguese settlements in China (Boston 1836) p. $73,74$.

2 Faria y Sousa als b.; Calendar III, No. 146. 
diepte. De commandeur besloot dus aan den Zuidwesthoek van Pehu een fort te bouwen en zond den opperkoopman Jan van Meldert met drie jachten naar Chincheu (Tsiuen tscheu), destijds nog de voornaamste zeeplaats aan de kust van Fukian, met het verzoek aan de Chineesche Overheid om daar handel te mogen drijven en aan de Hollanders een geschikte plaats tot residentie aan te wijzen. De gouverneur der stad verzocht de Hollanders te vertrekken; over vijftig dagen zou hij te Pehu antwoord zenden. Werkelijk kwamen daar den 1 October vier ('hineesche oorlogsjonken, met de boodschap van den gouverneur der provincie Fukian, dat zij geen handel konden bekomen en zich niet op Pehu mochten vestigen, daar dit eiland Chineesch rijksgebied was. Aan den noordhoek van Formosa, te Tanshwui, mochten zij zich vestigen; dit lag buiten het rijksgebied ${ }^{1}$.

Dat Reyersz hiermede geen genoegen nam, was te begrijpen. Er bleef na deze volstrekte weigering niets anders over dan oorlogsdwang. Cornelis van Nijenrode werd nu met acht schepen naar de Chineesche kust gezonden om te rooven en te brandschatten. Men vernielde een tachtigtal jonken bij Amoy, verbrandde eenige dorpen, lichtte een paar honderd Chineezen op om naar Batavia te zenden, maar leed ook zelf nu en dan verliezen. Reyersz en Nijenrode zagen dan ook weldra in, dat het zoo spoedig niet gelukken zou de Chineezen op deze wijze te dwingen om in hun politiek verandering te brengen, en zonden een deel van 't geld, dat hun voor den handel was toegezonden, naar Batavia terug. Coen moest zelf bekennen, dat de tocht tot nu toe "gansch vruchteloos was afgeloopen." Maar hij was niet de man om zich door een eerste vruchtelooze poging te laten afschrikken, hoewel Bewindhebbers hem hadden te kennen gegeven, dat de aanslag op Macao hun niet naar den zin was en Coen "zijne concepten te wijd uitstrekte." "Om den Chineeschen handel te verkrijgen", antwoordde hij hun, "moet gestadig naar onze meening naar Pehu en op de kust van China volk, schepen en geld gezonden worden, en wij moeten hun niet alleen den handel op Manila, Macao, Cochinchina en gansch Indië, nitgezonderd Batavia, beletten, maar hen daarenboven langs de geheele kust van China zoo zeer

1 Corn. Reyersz aan Coen, 10 Sept., 8 Oct. 1622, Coen als boven; Bontekoe, Journaal p. 30, 31 ; Wassenaer, Hist. Verhael, Dl. VII (1625) fol. 65-66. (Overgenomen als Inwerp in 't Journaal van Seger van Rechteren, in "Begin en Voortgang der O. I. Compagnie; II, bl. 46-47.)

5e Volgr. II. 
kwellen en incommodeeren als doenlijk is om de Chineezen daardoor te dwingen zelven raad en middel tot gevoegelijke accommodatie te zoeken. Gelijk ongetwijfeld geschieden zal." 2

Of Coen hierin juist zag, zullen wij later vernemen.

1 Coen asn Bewindh., 20 Juni 1623; Bontekoe, Journaal bl. 32-36; Bewindh. aan Coen, 14 Apr. 1622. 


\section{ZEVENDE HOOFDSTUK.}

Reis van Augustin de Beaulieu naar den Maleischen Archipel (1619-22). Wedervaren van zijn viceadmiraal te Batavia. Hij zelf bezoekt Atjeh, Kedah, Tiku. De Hollandsche factorij te Atjeh gelicht. De Sultan van Djohor door de Atjehers van Lingga verdreven. De Hollanders en Engelschen te Djambi, Indragiri, Palembang, Patani en in Siam (1620-23). Hunne kantoren aldaar, behalve te Djambi, worden opgeheven.

Het bleek ons reeds, dat de Franschen nogmaals een poging hadden gedaan om deel te bekomen aan de voordeelen van de vaart op den Maleischen Archipel. In 1619 waren te Dieppe twee schepen en een jacht daartoe uitgerust, de Montmorency, Espérance en Hermitage, die den \& October de haven van Honfleur verlieten. Aan boord van 't eerste bevond zich de gezagvoerder van 't eskader: Augustin de Beaulieu, die ook in 1616 onder Charles de Nets de reis had medegemaakt; aan boord van 't andere schip de vice-admiraal Robert Gravé. Men was thans, zoo 't schijnt, zoo voorzichtig geweest geene Hollanders in dienst te nemen 1. Den 28 Maart 1620 aan de Kaap gekomen, vonden zij op Pinguins-eiland onder een grooten steen een brief van Steven van der Haghen, dien hij den 2 Februari van dit jaar op zijn terugreis naar 't vaderland daar had achtergelaten, en waaruit bleek dat de Hollanders Bantam belegerd hielden en de Engelschen van daar vertrokken waren. Een andere brief, door de bemanning van het Engelsche jacht "the Bear" hier neergelegd, hield het bericht in van 't accoord tusschen de Hollanders en Engelschen gesloten.

Beaulieu vermoedde wel dat de Hollanders, hetzij zij Bantam veroverd hadden of niet, hem daar den handel niet zouden toestaan. Hij vond het daarom het veiligst naar de kust van Koromandel te

1 De naam van een "intreprète Indien" op het schip van Gravé, dien zij medenamen, Francisco Nicquet, doet vermoeden dat de Amsterdamsche kooplieden Nicquet, die tot de tegenstanders der O. I. Compagnie behoorden (zie mijne Bouwstoffen, Inleiding bl. LIX), niet vreemd waren aan deze expeditie. Dat die tolk een Maleier was van de Westkust van Sumatra is zeer waarschijnlijk, want toen hij met de boot van genoemd schip aan de kust was achtergelaten, ging hij in het binnenland peper plukken. 
gaan, daar kleeden te koopen die te Atjeh gebruikt konden worden en ter laatst genoemde plaats voor één schip peper te laden of voor beiden, indien het beleg van Bantam voortduurde. Werd dit opgeheven, dan kon hij een schip en het jacht naar Bantam zenden, en het laatste daar als legger achterlaten.

Zeker zou het verstandig geweest zijn, indien hij zich aan dit plan had gehouden. Maar zijne orders overlezende, bevond hij dat zijne principalen zeer stellig wenschten dat hij dit jaar nog een der schepen geladen terug zou zenden. Ten einde aan dat verlangen te kunnen voldoen nam hij nu den halven maatregel om zijn Vice-admiraal rechtstreeks naar Bantam te zenden; hij zelf zou dan met het jacht eerst de de kust van Koromandel bezoeken en vervolgens naar Atjeh gaan. Den 1 Mei nam Gravé aan de Afrikaansche kust van den admiraal afscheid en vervolgde ieder zijn weg. Beaulieu werd lang opgehouden en voer eerst vier maanden later kaap Komorin om; hij besloot nu geen tijd meer te verliezen en rechtstreeks naar Tiku te gaan, dat Gravé ook eerst zou aandoen voor hij zich naar Bantam begaf. Door tegenwind en windstilte bereikte hij Tiku niet voor den 2 December 1620, na veel volk verloren te hebben. De Hollanders en Engelschen hadden hier kort te voren hunne factorijen opgebroken, daar de Sultan van Atjeh hun alleen den handel in zijne hoofdplaats wilde vergunnen. Een Malabaar, die hier als tolk van de Engelschen dienst had gedaan, bracht hem een brief door twee manschappen van Gravé's equipage geschreven. Hieruit vernam hij voor een deel hetgeen met den vice-admiraal was voorgevallen en wat wij uit de latere berichten willen aanvullen.

Gravé was in Juli aan de kust van Pageh (Nassau-eilanden, westelijk van Sumatra) aangekomen en had door tegenwind Tiku niet kunnen bereiken, maar een boot met 15 man daarheen gezonden om verversching en drinkwater te bekomen. Dit gelukte ook, maar de boot kon het schip niet weervinden en was dus genoodzaakt naar Tiku terug te keeren, waar de helft der manschappen stierf. De overigen vertrokken op Hollandsche schepen naar Bantam; alleen de tolk bleef in zijn land achter.

De bemanning van l'Espérance had intusschen veel ellende geleden. De eerste kommies, Le Tellier, was zeer ziek geworden en had verlangd dat men hem naar Tiku zou brengen, maar wat Gravé ook beproefde, hij kon die kust niet bereiken. Het volk was gaandeweg zoo door ziekten verzwakt, dat men het schip niet meer sturen kon. In deze nood ontmoette men het Hollandsche schip Leyden, 
waarop schipper was de ons welbekende Willem Cornelisz Schouten. Het was geen gelukkig samentreffen. Schouten was schipper geweest op het schip van Le Maire, dat door Coen te Batavia in beslag was genomen, en bij zijn terugkomst te Amsterdam in dienst van de Compagnie overgegaan. Om zijn ijver te toonen, zoo het schijnt, behandelde hij de Franschen als sluikers en toonde niet het minste medelijden met de arme zieken. $\mathrm{Na}$ nog andere wederwaardigheden werd l'Espérance in December te Batavia opgebracht. Van de 124 man, waaruit de equipage bestaan had, waren er slechts 29 overgebleven. De Raad van defensie besloot dadelijk het schip met de goederen, zoo als men het had aangetroffen, aan de Franschen terug te geven. Le Tellier verzocht nu aan Coen assistentie om te Bantam peper te koopen. Coen wilde daar eerst niets van hooren, maar de Raad besloot hem dit niet te beletten, mits hij niet meer dan een bepaalden prijs voor de peper gaf, de lasten betaalde die de Rand vast zou stellen en twee derden van het gekochte aan de Hollanders en Engelschen afstond, die elk tien man tot assistentie mede gaven. Kort hierop kregen de Franschen eenige versterking met het jacht l'Hermitage dat Beaulieu hun toezond. In 't laatst van Januari 1621 kwamen zij te Bantam en werden daar welwillend ontvangen ${ }^{1}$. De Pangeran stond hun toe een huis te bouwen en peper te koopen, maar alleen van hem, en onder voorwaarde dat zij er niets van aan de Hollanders en Engelschen zouden afstaan, op verbeurte van lijf en goed. Dat Gravé die voorwaarde aannam, bewijst wel dat hij geen plan had zich aan die van den Raad van defensie te houden. De Pangeran hield echter de peper zoo hoog in prijs, dat de Franschen eerst geen aankoopen wilden doen. Gravé liet nu aan Coen vragen of hij zijn aandeel nog begeerde, indien hij de peper duurder kocht en ontving een ontkennend antwoord. Dit antwoord zal wel een volstrekt verbod zijn geweest om duurder te koopen. Maar toen nu de koop met den Pangeran gesloten was, kwam het uit dat Gravé slechts geld genoeg had om een klein deel van het aangebodene te betalen en daarvan wilde de Pangeran niets hooren. Gravé sloot nu eene overeenkomst met André Joret de Limonaye, een factor van de compagnie van Saint-Malo, die te Bantam was achtergebleven en peper in voorraad had. Limonaye deed hem dien voorraad over tegen afstand van 't jacht l'Hermitage, met eenig geld en goederen.

\footnotetext{
1 Le Tellier moest wegens ziekte te Batavia achterblijven en stierf daar kort daarna.
} 
Toen l'Espérance geladen was maakte Gravé aanstalten om naar Atjeh te gaan, waar Beaulieu zich toen bevond. De Raad van defensie had echter gezorgd dat hij hun niet zou ontsnappen, en schip en jacht werden nu door de Hollandsche schepen, die voor Bantam lagen, naar Batavia opgebracht (27 Mei 1621). Hier werd Gravé gelast om volgens overeenkomst twee derden van de lading uit te leveren. Hij weigerde, omdat hij er een hooger prijs voor gegeven had dan de Raad betalen wilde. $\mathrm{Nu}$ werden de Fransche officiers aan land in verzekerde bewaring gehouden en begonnen de Hollanders zelven de peper uit het schip te lossen. Men was daar nog mede bezig, toen in den nacht van 16 Juni de Franschen bespeurden dat hun schip in brand stond en aanstonds met de Hollanders die aan boord waren in de booten sprongen om zich te redden, zonder moeite te doen om het vuur te blusschen. De oorzaak van dit ongeval bleef onbekend; de Franschen en Hollanders gaven er elkander weerkeerig de schuld van. De Raad van defensie wilde nu voor de peper aan Gravé den prijs betalen, dien zij, op gezag van Chineezen uit Bantam, beweerde dat hij er voor gegeven had. Maar de Franschman begreep wel dat zijne Regeering hooger schadevergoeding zou kunnen bedingen, en weigerde. Hij zond nu eenigen der zijnen in een prauw naar Atjeh en werd met de overigen door Limonaye daarheen gebracht in het jacht.

Wij verlieten Beaulieu in December 1620 ter reede van Tiku. Men vergunde hem zijne zieken aan land te brengen maar niet om peper te koopen. Hij zond nu het jacht naar Bantam en voer in 't begin van Januari 1621 naar Atjeh. De Sultan, voor wien hij eenige kostbare wapens medebracht, gaf hem een plechtige ontvangst. Iskander was omtrent de verhouding tusschen de Europeërs zeer goed op de hoogte. Hij begreep dus wel, dat hij bij den Franschman instemming zou vinden, als hij zich over de Hollanders en Engelschen ongunstig uitliet, want Beaulieu had reeds vernomen hoe Gravé en de zijnen door hen waren behandeld. Het was hun slechts te doen, zeide de Sultan, om den geheelen Indischen handel in handen te krijgen en daartoe deden zij niets dan rooven en buiten. Hij gunde hun daarom zijn peper niet, zelfs niet voor den hoogen prijs dien hij er voor bepaald had, nadat de Sultan van Bantam de peperranken in zijn gebied had laten uitroeien. Beaulieu antwoordde, dat zij onder den schijn van handel meesters wilden worden, maar wat hem betreft, hij kwam alleen als handelaar en had geen last om iemand het zijne te ontnemen of zich ergens te versterken. 
Hoe welgezind de Sultan zich ook toonde, de Franschen bespeurden weldra dat zij de peper geen penning goedkooper zouden krijgen dan de Engelschen of Hollanders. Iskander was zelf een geslepen koopman en gunde anderen geen voordeel. Hij liet zelfs in dezen tijd een schip uitrusten om peper naar Mocha te brengen 1 en scheen die na den komst van Beaulieu nog meer op prijs te houden, zoodat de Raad van defensie besloot de kantoren te Atjeh te lichten 2. Na de Franschen een tijd land aan de praat gehouden te hebben tot hij begreep niets meer van hen te kunnen halen, stond de Sultan hun eindelijk toe, maar tegelijker tijd ook aan de Engelschen en Hollanders, voor iets lager prijs elk 300 bahar peper aan te koopen. Maar ze kwamen Beaulieu en de Hollanders ${ }^{3}$ de helft duurder te staan dan de Engelschen, want hun eenig betaalmiddel was realen die hier niet gewild waren, terwijl de Engelschen hier een goeden voorraad kleeden van Surate hadden aangebracht.

Te vergeefs trachtte Beaulieu den Sultan over te halen hem den handel te Tiku toe te staan. Iskander eischte daarvoor zulk een hooge som, dat hij er geen voordeel in zag. Hij mocht dus hier zijn tijd niet langer verspillen, te meer daar zijn volk in dit klimaat geen leefregels in acht wilde nemen en velen hunne zorgeloosheid met den dood moesten bekoopen. Hij had van de Portugeesche gevangenen, die zich hier bevonden, vernomen dat op het eilandje Lada, dat onder Kedah stond 4, de peper de helft goedkooper te krijgen was dan hier en besloot nu eene poging te doen om daar lading op te doen. Den 24. Juli verliet hij Atjeh en veertien dagen later wierp hij voor Lada het anker uit. Werkelijk groeide hier veel peper, die de Portugeezen te Malaka vroeger voor een lagen prijs opkochten, maar sinds drie of vier jaren was ten gevolge van de rooftochten der Atjehers en de verwoesting van Kedah de peperteelt achteruitgegaan en waren de inwoners hier en op het vasteland zoo schuw geworden, dat zij bij de komst van een schip in de bosschen vluchten. Wat men nog oogstte, werd nu naar Djambi gebracht om daar te verkoopen. De Sultan van Kedah had zich aan de rivier vau Parlis in het binnenland gevestigd 5 en onder bescherming gesteld van den

\footnotetext{
${ }^{1}$ Coen aan Bewindh., 8 Januari 1621.

2 Pt. de Carpentier aan Bewindh., 9 Juli 1621; Calendar, III, p. 20.

3 Coen aan Bewindh., 20 Decmber 1621.

4 Hij schrijft Pulu Lankawi of Lada, maar Lada is een klein eiland bezuiden het grootere Langkawi. Pulu Lada beteekent: pepereiland.

${ }^{5}$ Beaulieu noemt de plaats Ouantchin.
} 
Koning van Siam, die hem zoo men zeide 2000 man te hulp had gezonden en een voorraad rijst, want daar de Atjehers alle vruchtboomen uitgeroeid en alle buffels gedood hadden, heerschte er hongersnood. De panghulu van Lada mocht Beaulieu den handel niet vergunnen zonder toestemming van Kedah, zoodat hij genoodzaakt was een gezant naar den Sultan af te vaardigen. Deze verkreeg zijne toestemming onder beding dat Beaulieu hem een kanon zou afstaan. Maar de Franschen hadden intusschen reeds bemerkt dat er geen peper in voorraad en de nieuwe oogst eerst in December te wachten was. Zoo lang te toeven was niet raadzaam. De sterfte onder het het volk bleef voortduren en de overblijvenden kregen heimwee. Den 12 October keerde dus Beaulieu naar de kust van Sumatra terug, en niet ver van Atjeh het anker uitwerpende, ontving hij weinig geruststellende berichten omtrent zijne landgenooten die van Batavia waren aangekomen. Terwijl hij zich gereed makkte zelf naar Atjeh te gaan, kwam een Engelsch schip op hem af en zond een boot uit, waarin hij tot zijn verbazing een officier van Gravé opmerkte. Het bleek nu dat de vice-admiraal eenige dagen te voren in het jacht van De Limonaye te Atjeh was aangekomen, daar zeer ziek was geworden, en, toen hij Beaulieu niet vond, zich bij den Engelschman, die naar Batavia voer, had ingescheept, om van daar naar Europa terug te keeren. De Franschen gingen nu op Beaulieu's schip over en van hen vernam de admiraal, dat de prauw met manschappen, die Gravé naar Atjeh vooruit had gezonden, door den Sultan was prijs verklaard.

Toen Beaulieu, te Atjeh gekomen, zich over dezen maatregel van geweld beklaagde, werden hem zijne manschappen aanstonds uitgeleverd, maar wat zij aan waarde bij zich gehad hadden, bleef volgens het heerschende recht des Sultans eigendom, omdat zij "als verloren en verlaten lieden" in zijn land waren gekomen. Hij was thans echter gelukkiger in zijne pogingen om vergunning te bekomen te Tiku peper te koopen. Dit werd hem voor 20 dagen toegestaan. Hij haastte zich nu van die vergunning gebruik te maken, en den 1 Januari 1622 was zijn schip te Tiku volladen. Een maand later nam hij met 75 man de terugreis aan en kwam behouden in het vaderland terug 1 .

1 Mémoires du voyage aux Indes Orientales du général Beaulieu, dressés par luy-mesme, in (Thévenot's) Relations de divers voyages curieux etc., 2e partie (Paris 1666); Resolutien Gouv. Gen. en Raden Dec. 1620; Documenten betr. den Raad van defensie 1620-21; Brieven van Coen en Carpentier aan Bewindh. 1621-22. 
Hoe het met het jacht "l'Hermitage" afliep, dat Limonaye herdoopte in "Petite Espérance", vernemen wij uit Hollandsche berichten. Den 14. Februari 1622 vertrok het van Atjeh, en werd kort daarna aan de kust van Malaka door een Hollandsch schip in arrest genomen en naar Djambi opgebracht. De Hollandsche factor te Djambi haastte zich evenwel het arrest op te heffen. Limonaye gebruikte toen heí jacht een tijd lang om van Djambi uit kleine handelstochten te ondernemen, totdat het vaartuig lek en onbruikbaar was geworden en hij het bij gebrek aan volk moest verlaten. Den dood van eenigen zijner manschappen schreef hij aan de Hollanders toe, met welk recht vernemen wij niet. Maar dat hem onrecht geschied was, blijkt wel daaruit dat Coens opvolger Pieter de Carpentier over 't verlies van zijn jacht met hem in accoord wilde treden, 't geen Limonaye weigerde, daar hij in Frankrijk beter vergoeding hoopte te bekomen. Nog in Novernber 1623 vind ik dat "Guillaume Gautier, zich noemende eerste koopman van de Compagnie van Saint-Malo", met een jacht voor Djapara lag en van Carpentier een pas verzocht om "op verscheidene kwartieren handel te drijven", welke pas hem werd toegestaan 1.

De Sultan van Atjeh begon in 1622 in te zien dat hij zijn streng niet te vast moest houden, en toen hij vernam dat de Hollanders en Engelschen te Djambi en elders veel peper bekwamen en misschien ook dat zij last gegeven hadden hun kantoor te Atjeh te lichten, werd hij schappelijker en stelde hen in staat eene lading op te doen. Coen bleef echter bij zijn besluit, en in Maart 1623 werd de Hollandsche opperkoopman Nicolaas de Casembroot teruggeroepen. Op het dringend verzoek van den Sultan liet hij een assistent achter, en de Hollandsche schepen bleven Atjeh bezoeken. De Engelschen bleven in hun factorij, maar eerst na twee jaar, in Mei 1623, kwam hier weder een hunner schepen lading innemen. Hun factor George Robinson was in ongenade gevallen, omdat hij te spaarzaam was met geschenken, en werd toen door een ander vervangen 2 .

${ }^{1}$ Nic. de Casembroot aan Coen, uit Atjeh, 18 Febr. 1622; Coen aan Bewindh. 6 Sept. 1622; Carpentier aan dez. 24 Febr. 1623; Uitgaand Briefboek v. Batavia 15 Nov. 1623.

${ }^{2}$ Coen aan Bewindh. 26 Mrt., 6 Sept. 1622; 20 Juni 1623; Nic. Casembroot aan Coen, 18 Febr. 1622 ; Calendar II, p. 486, 496; III, p. 62, 111, 207 en No. 328. 
In 't begin van 1623 ontving de Sultan van Djohor, Hammat $\mathrm{Sjah}$, van Atjeh den genadeslag. Hij had zich in 1618 op 't eiland Lingga gevestigd 1, op een plaats waar hij voor een insluiting door de Atjehers niet behoefde te vreezen. Zijn voornaamste inkomsten trok hij uit den handel op Malaka. De jonken van Siam, Patani, Java, Makassar enz. kwamen te Lingga en te Bintang rijst en andere benoodigdheden brengen, die dan met klein vaartuig naar Malaka vervoerd werden. Coen, die hem nog altijd te vriend hield om den invloed, dien hij bezat op de vorsten ter oostkust van Sumatra, had hem echter reeds meer dan eens doen weten dat hij aan de jonken, die in zijne havens kwamen, geen vrịppas meer zou geven als hij de vaart op Malaka niet naliet. Maar de voordeelen van die vaart waren voor hem een levenskwestie; het heette nu dat hij den steun van Malaka tegen Atjeh te veel noodig had. Toen echter in 't begin van Maart 1623 de Atjehsche vloot naar Lingga in aantocht was, lieten de Portugeezen zich niet aan hem gelegen liggen. Al wat vluchten kon maakte zich in prauwen uit de voeten, en wie achterbleven werden door de Atjehers, nadat zij de nieuwe residentie verwoest hadden, medegesleept. Hammat nam de wijk op het eiland Tambelan beoosten Borneo, waar hij drie maanden later van hartzeer stierf. Zijn neef, de zoon van den vorigen Sultan, werd als zijn opvolger erkend onder den naam van Abdul Djalil Sjah II. Hammats gemalin, eene dochter van den Sultan van Djambi die hij kort te voren gehuwd had, keerde met haar zoontje naar haar vader terug ${ }^{2}$.

De Maleische staatjes aan Sumatra's oostkust werden door Iskander nog met vrede gelaten, misschien omdat hij eene botsing met de Hollanders wilde vermijden. Te Djambi had het stelsel van zeeroof, door Coen ingevoerd, de laatsten in 1620 veel last en schade berokkend. Niet alleen hadden Hollandsche schepen te Gresik de jonken, die met peper van Djambi kwamen, gelwongen die voor lagen prijs aan hen af te staan, maar ook de "vrijlieden" van Batavia $\mathbf{3}$ hadden

1 Coen zegt: "aen 't eylandt Linga tusschen veel eylanden en droochten, ter plaetse, daer in noot van vluchten can, genaemt Benaww" (Penuba?)

2 A. Soury aan Bewindh. 25 Sept. 1618; Coen aan dez. 6 Sept. 1622; Coen aan den "Coning van Jhoor" en aan "Raja Mora Panglima van Linggau, 1 Mei, 26 Mei 1622; Resol. Gouv. Gen. en Raden 20 Mei 1622; A. Jz. van der Dussen aan Pt. de Carpentier 3 Maart, 14 Maart, 23 Sept. 1623; Pt. de Carpentier aan Bewindh. 5 Januari 1624. Vgl. E. Netseher, De Nederlanders in Djohor en Siak, bl. $31-32$.

s Zie hiervoor bl. 290. 
een van des Sultans jonken geplunderd en verbrand. De factor te Djambi, Adriaen van der Dussen, werd gedwongen hem die schade te vergoeden. Coen was hevig verontwaardigd over dezen gewelddadigen maatregel, maar het geld werd niet teruggegeven. De Sultan begreep echter dat het in zijn belang was Coen te belooven, dat hij zijne jonken met peper voortaan naar Batavia zou zenden. Coen zou op die belofte het kantoor gelicht hebben, indien de Engelschen hem niet in den weg hadden gezeten. Dezen hadden de gunst van den Sultan gewonnen door het voorstel om op een eilandje in de rivier, ter plaatse waar men de vaart op Djambi kon beheerschen, een fort te maken, dat de stad tegen een aanval van de Atjehers kon beveiligen. Maar in 1622 begon het hun, zoo als in al hun factorijen, aan middelen te ontbreken, zoodat zij niet meer van het fort repten. De Hollanders daarentegen werden steeds van kapitaal voorzien en herkregen daardoor hun invloed, terwijl de Engelschen zeer in minachting kwamen '.

Ook te Indragiri en te Palembang waren Hollanders noch Engelschen meer veilig na de rooftochten der vrijlieden. Hoewel het kantoor te Palembang in 1621 werd opgeheven, ontving de Sultan den koopman Druyff, die in 1622 door Coen werd afgezonden om zich te verontschuldigen over 't gebeurde en hem geschenken te brengen, wel met veel eerbewijs, maar toen kort daarna een Hollandsch jacht hier kwam handelen, werd de bemanning door een Chinees gewaarschuwd niet aan land te gaan, omdat het anders slecht met hen zou afloopen. Te Indragiri werd in 1622 een Hollandsch jacht met geschut en lading verbeurd verklaard, en ook aan de Engelschen zooveel schade berokkend, dat beide natiën hunne factorijen ophieven. De Hollanders bleven echter de plaats bezoeken, omdat nu en dan "goede partijen peper" de rivier afkwamen 2.

$\mathrm{Na}$ de verdrijving van Hammat Sjah uit Lingga sloten Palembang en Djambi zich weder nauwer bij elkander aan. In 1623 zond de Sultan van Palembang zijn broeder naar Djambi om de Sultansdochter

1 Brieven gewisseld tusschen de Gouv. Generaals en A. Jz. van der Dussen, factor te Djambi, 1620-23; Carpentier aan Bewindh. 9 Juli 1621; Coen aan dez. 16 Nov. 1621, 6 Sept. 1622; Verhael van eenige oorlogen in Indie (1622) in Kronijk van 't Hist. Gen. 1871, bl. 567-69; Calendar II, No. 1174; III, No. 143 (p. 62) No. 264 (p. 111) No. 353, 356, 367.

2 Coen aan Jan Jansz Hoochlant te Palembang, 2 Sept. 1622; Dez. aan Bewindh. 6 Sept. 1622, 20 Juni 1623; Dez. aan A. Jz. van dex Dussen te Djambi, 26 Nov. 1622; Claes Pietersz Puyner uit Indragiri aan A. Jz. van der Dussen, 10 Febr. 1623. 
voor zijn zoon ten huwelijk te vragen '. Zelfs aan de oostkust van 't Maleische schiereiland werden met het oog op aansluiting tegen Atjeh dergelijke verbindtenissen aangegaan. In 1620 huwde de radja van Bondelong (de oudste zoon van den vorst van Ligor) met de zustersdochter en erfgename der vorstin van Patani 2. Ook de vriendschap der Hollanders werd daar meer dan vroeger gezocht. In 1620 zond de vorstin van Patani een gezant met geschenken naar Batavia, die haar moest verontschuldigen dat zij genoodzaakt was. geweest "ten einde haar kust te beveiligen" vrede met Malaka te sluiten 3. Maar Coen nam die verontschuldigingen niet aan en verlangde dat de Pataneezen de vaart op Malaka zouden staken. Hij begreep echter wel dat hij de Maleiers niet met geweld kon dwingen hunne vaartuigen alleen naar Batavia te zenden, zoolang hij factorijen aan de kust bleef houden, en besloot dus het voordeel dat deze aanbrachten aan zijn wensch om Batavia groot te maken op te offeren 4. In Mei 1622 werd Druyff uitgezonden om de kantoren te Patani, Sangora, Bondelong, zoowel als die in Siam en Kambodja (waar men zich juist gevestigd had) te lichten. Voor den vorst van Siam was dit een te grooter teleurstelling, omdat hij Coens hulp gevraagd had tegen Kambodja, waar de zoon van den overleden Siameeschen gouverneur zich tot onafhankelijk vorst had opgeworpen. Op zijn verzoek werd een assistent te Ajudhja achtergelaten 5.

Het opheffen van al die factorijen werd door velen afgekeurd. "Mijns bedunkens", zoo liet een hunner zich over Coen uit, "wordt deze man razend en uitzinnig. Ik weet niet wat hij voor heeft, of hij moet geheel Indië te roof willen stellen, maar het zal ons zwaar vallen van den dag nacht te maken." 6 Zelfs Pieter de Carpentier was

1 A. Jz. van der Dussen aan Pt. de Carpentier, 23 Sept. 1623.

2 G. Fz. Druyff aan Coen, 4 Nov. 1620.

s Coen aan Bewindh., 8 Jan. 1621 "Den Atchijnder", voegt hij er bij, "is het dien de Pataners vreezen."

4 Resol. GG. en Raden, 4 Aug., 16 Dec. 1621.

5 Koning van Siam aan Coen, 5 Jan. 1622; Coen aan Bewindh. 26 Maart 1622; 20 Juni 1623. - De Siameesche gouverneur in Kambodja wordt genoemd "Prafery Soubhaima de Raya", de zoon Tchesta". Twee Siameesche legers, een te land en een te water, werden naar Kambodja gezonden. Het laatste keerde onverrichter zake terug. Het eerste werd in een hinderlaag gelokt en verslagen. Men zegt dat 17000 man en 250 olifanten aan Tchesta in handen vielen (Brieven van Coen als b.)

- Rapport gedaen by verscheyden personen comende vuyt de O. I. (1622) in Kronijk van 't Hist. Gen. 1871, bl. 333. Vgl. het Verhaal van eenige oorlogen in J., aldaar bl. 570,572 . 
er blijkbaar niet mede ingenomen. "Door 't lichten van 't kantoor in Siam", schreef hij aan Bewindhebbers, zijn ons groote uitvoeren naar Japan van hertevellen en sapanhout ontgaan, waaraan de Japanners nu zelven een kapitaal verdiend hebben." I

De verstandhouding tusschen de Hollanders en Engelschen liet te Patani na het accoord een tijdlang niets te wenschen over ${ }^{2}$, maar de pertinente bevelen van Coen om den mededinger zooveel mogelijk tegen te werken ${ }^{3}$ maakten daar spoedig een eind aan. De Hollanders wisten te beletten dat de Engelschen zich te Sangora vestigden. Daarentegen moedigde de vorst van Ligor hen aan in zijne hoofdplaats eene factorij op te richten. Maar door gebrek aan kapitaal moesten zij niet alleen van dat plan afzien, maar 1622 besluiten ook hunne factorijen in Siam en te Patani op te heffen. 4

1 Pt. de Carpentier aan Bewindh., 3 Jan. 1624.

2 Pring bij Purchas, I b, p. 648; Calendar, II, No. 921.

3 Coen aan G. Fz. Druyff, 3 Juli; Druyff aan Coen, 4 Nov. 1620.

4 Calendar, II, No. 973, 1013, 1048, 1051, 1069, 1070, 1074, 1099; III, No. 9 p. 5 ; No. 143 p. 62 ; No. 264 p. 110 , 111, No. 368 p. 205 ; Jan van Hasell te Sangora aan Coen, 4 Oct. 1620. 